\title{
Current Renewable Energy Technologies and Future Projections
}

\section{February 2007}

Prepared by

Stephen Allison

Melissa Voss Lapsa

Christina Ward

Barton Smith

Kim Grubb

Russell Lee 


\section{DOCUMENT AVAILABILITY}

Reports produced after January 1, 1996, are generally available free via the U.S. Department of Energy (DOE) Information Bridge:

Web site: http://www.osti.gov/bridge

Reports produced before January 1, 1996, may be purchased by members of the public from the following source:

National Technical Information Service

5285 Port Royal Road

Springfield, VA 22161

Telephone: 703-605-6000 (1-800-553-6847)

TDD: 703-487-4639

Fax: 703-605-6900

E-mail: info@ntis.fedworld.gov

Web site: http://www.ntis.gov/support/ordernowabout.htm

Reports are available to DOE employees, DOE contractors, Energy Technology Data Exchange (ETDE) representatives, and International Nuclear Information System (INIS) representatives from the following source:

Office of Scientific and Technical Information

P.O. Box 62

Oak Ridge, TN 37831

Telephone: 865-576-8401

Fax: $865-576-5728$

E-mail: reports@adonis.osti.gov

Web site: http://www.osti.gov/contact.html

This report was prepared as an account of work sponsored by an agency of the United States Government. Neither the United States government nor any agency thereof, nor any of their employees, makes any warranty, express or implied, or assumes any legal liability or responsibility for the accuracy, completeness, or usefulness of any information, apparatus, product, or process disclosed, or represents that its use would not infringe privately owned rights. Reference herein to any specific commercial product, process, or service by trade name, trademark, manufacturer, or otherwise, does not necessarily constitute or imply its endorsement, recommendation, or favoring by the United States Government or any agency thereof. The views and opinions of authors expressed herein do not necessarily state or reflect those of the United States Government or any agency thereof. 
ORNL/TM-2007/2

\title{
CURRENT RENEWABLE ENERGY TECHNOLOGIES AND FUTURE PROJECTIONS
}

\author{
Stephen Allison \\ Melissa Voss Lapsa \\ Christina Ward \\ Barton Smith \\ Kim Grubb \\ Russell Lee
}

February 2007

Prepared by

OAK RIDGE NATIONAL LABORATORY

P.O. Box 2008

Oak Ridge, Tennessee 37831-6285

managed by

UT-Battelle, LLC

for the

U.S. DEPARTMENT OF ENERGY

under contract DE-AC05-00OR22725 



\section{CONTENTS}

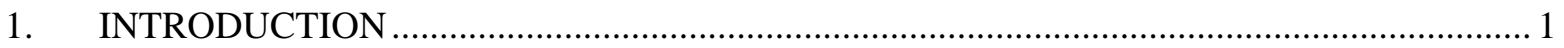

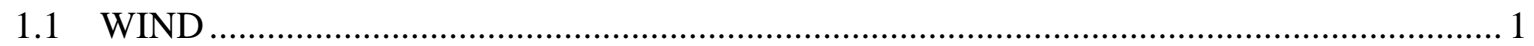

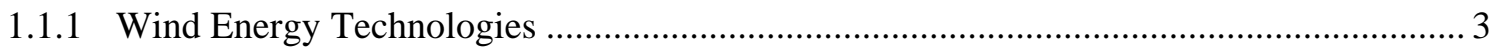

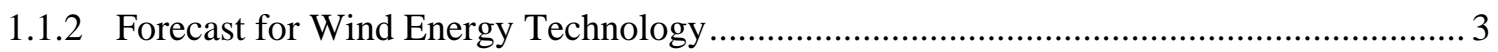

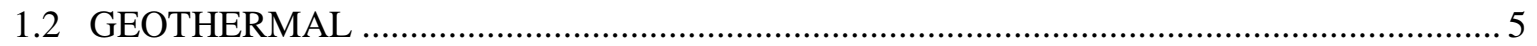

1.2.1 Geothermal Heat Pump Technologies ........................................................................... 5

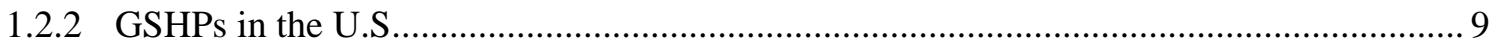

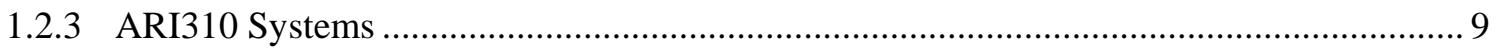

1.2.4 Geothermal Energy Power Generation ....................................................................... 9

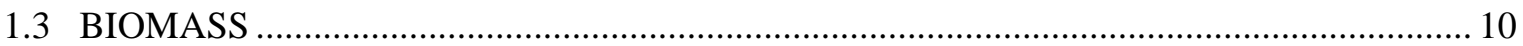

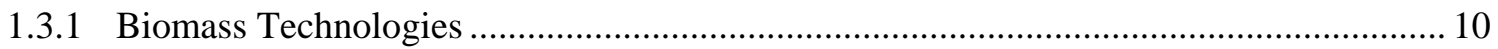

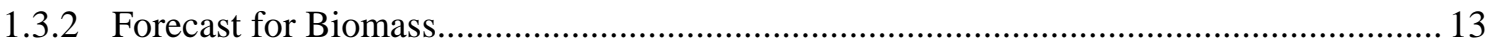

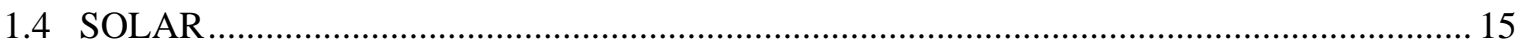

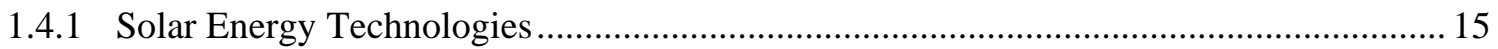

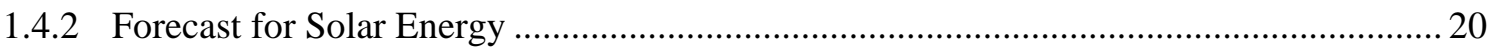

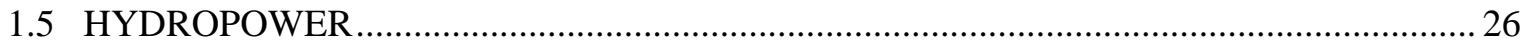

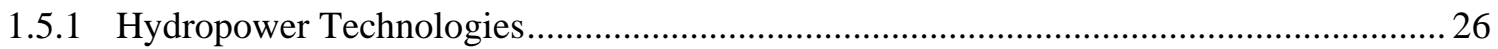

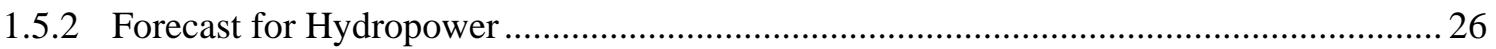

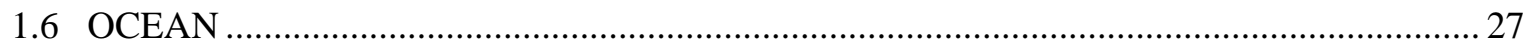

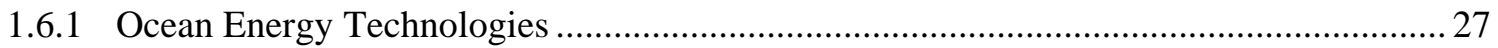

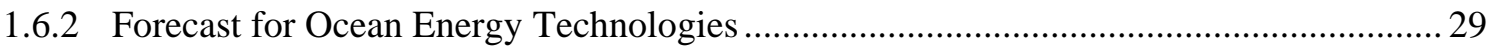

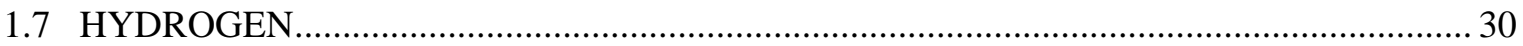

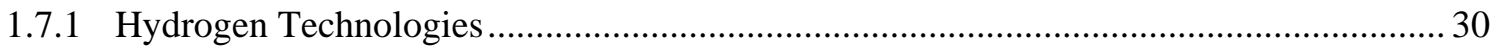

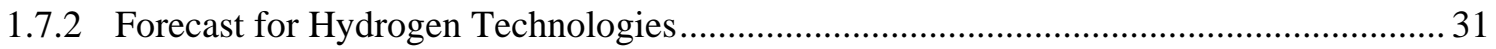

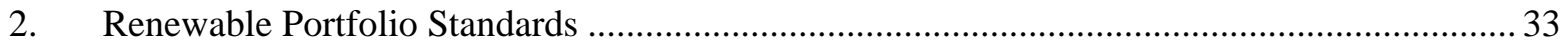

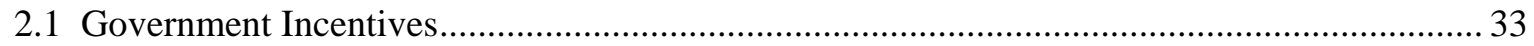

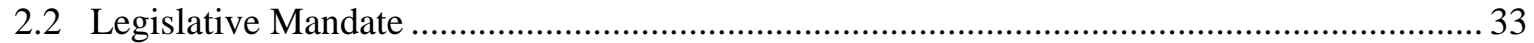

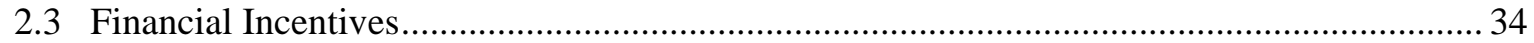

2.4 A Closer Look at Recent Tax Credits and Loan Guarantees for Renewable Energy .............. 35

2.4.1 Major Production Tax Credit Provisions in the Energy Policy Act of 2005 (EPACT) ..... 35

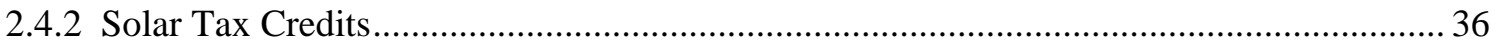

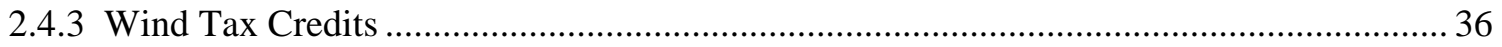

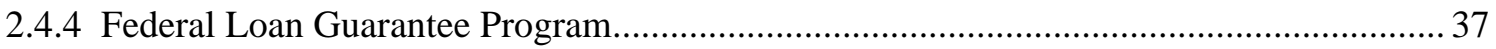




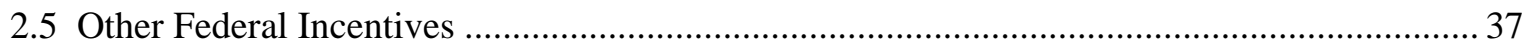

2.6 Technology-Specific Incentives from the Federal Government.......................................... 38

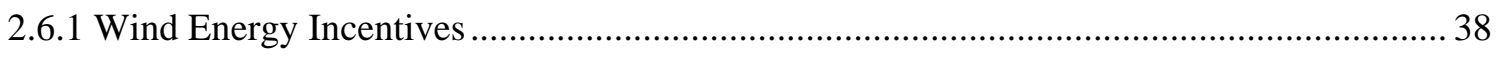

2.6.2 PV System (Solar Panel) Incentives............................................................................. 39

2.6.3 Biomass and Waste-to-Energy Incentives........................................................................ 39

2.7 Incentives in Other States for Renewable Energy .............................................................. 39

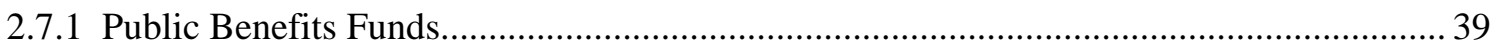

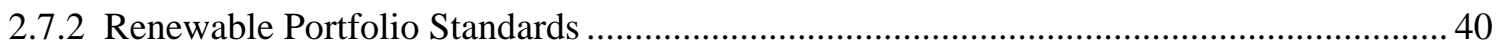

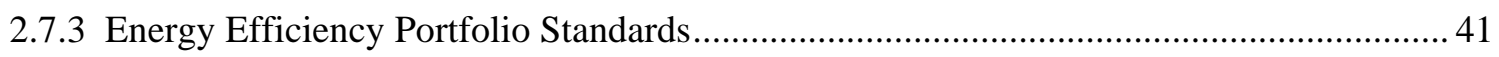

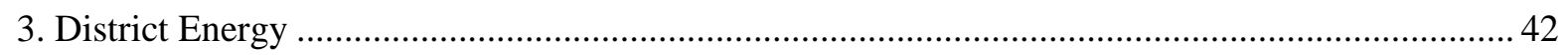

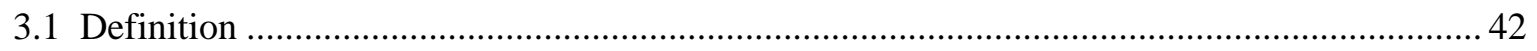

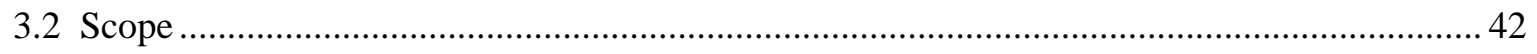

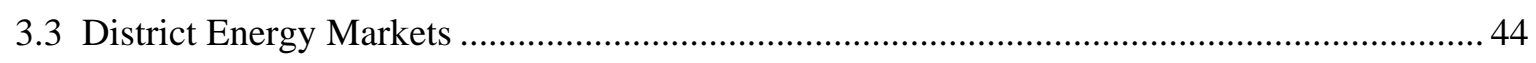

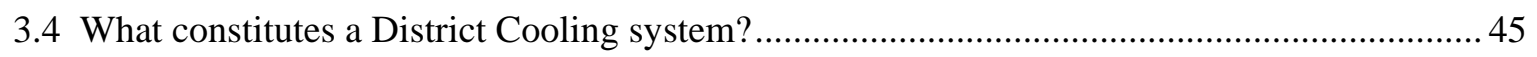

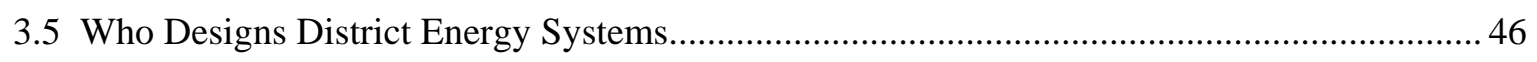

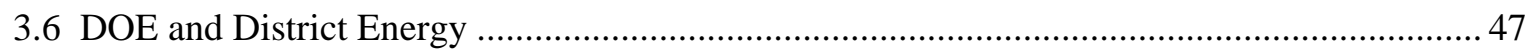

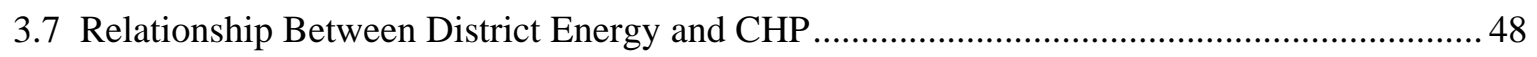

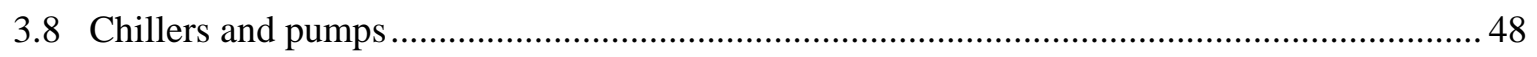

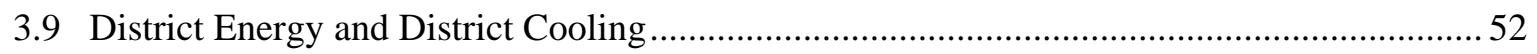

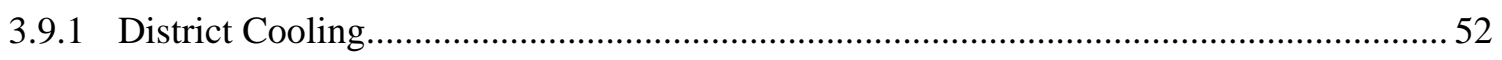

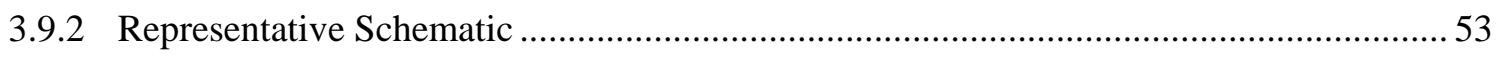

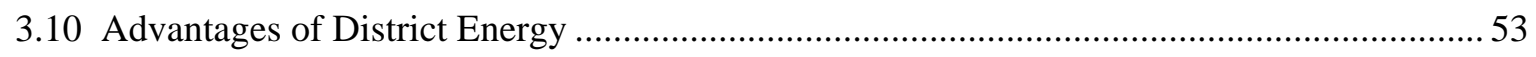

3.11 The Use of Copper for District Energy ……................................................................... 54

4. THE FUTURE OF RENEWABLE ENERGY TECHNOLOGIES THAT USE COPPER........55

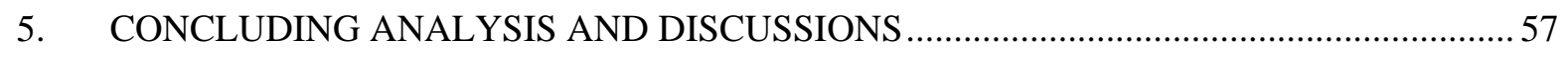

5.1 Method for Determining Copper per Megawatt................................................................ 57

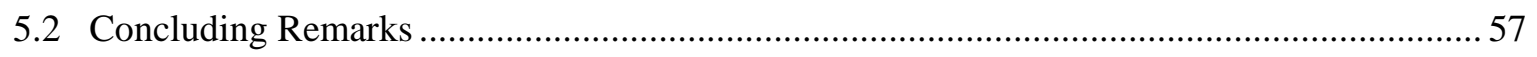

Appendix A: CopperHeart Integral Collector Storage System ................................................... A-1

Appendix B: IDEA CASE STUDY: College Campus CHP University Of Texas-Austin............... B-1

Appendix C: District Energy Case Study: City of Phoenix .......................................................... 


\section{LIST OF FIGURES}


LIST OF TABLES 


\section{INTRODUCTION}

The generally acknowledged sources of renewable energy are wind, geothermal, biomass, solar, hydropower, and hydrogen. Renewable energy technologies are crucial to the production and utilization of energy from these regenerative and virtually inexhaustible sources. Furthermore, renewable energy technologies provide benefits beyond the establishment of sustainable energy resources. For example, these technologies produce negligible amounts of greenhouse gases and other pollutants in providing energy, and they exploit domestically available energy sources, thereby reducing our dependence on both the importation of fossil fuels and the use of nuclear fuels. The market price of renewable energy technologies does not reflect the economic value of these added benefits.

This section briefly describes the renewable energy technologies being implemented in the U.S., and it details aspects of copper's contributions in making the technologies succeed.

\subsection{WIND}

Wind energy is derived from solar energy. Solar radiation heats the various geographical areas in widely varying ways. Water and land absorb solar radiation at different rates, and these geographical areas retain and transfer heat at different rates. These differences in heat transfer rates produce temperature gradients in the atmosphere: hot air rises and cold air is drawn down to replace it. Since air has mass, this upward and lateral motion of warm and cold air masses (wind) possesses kinetic energy. Some portion of this wind energy can be used for work and conversion to other forms of energy. Figure 1 is a wind resource map showing how the wind resources vary across the United States.

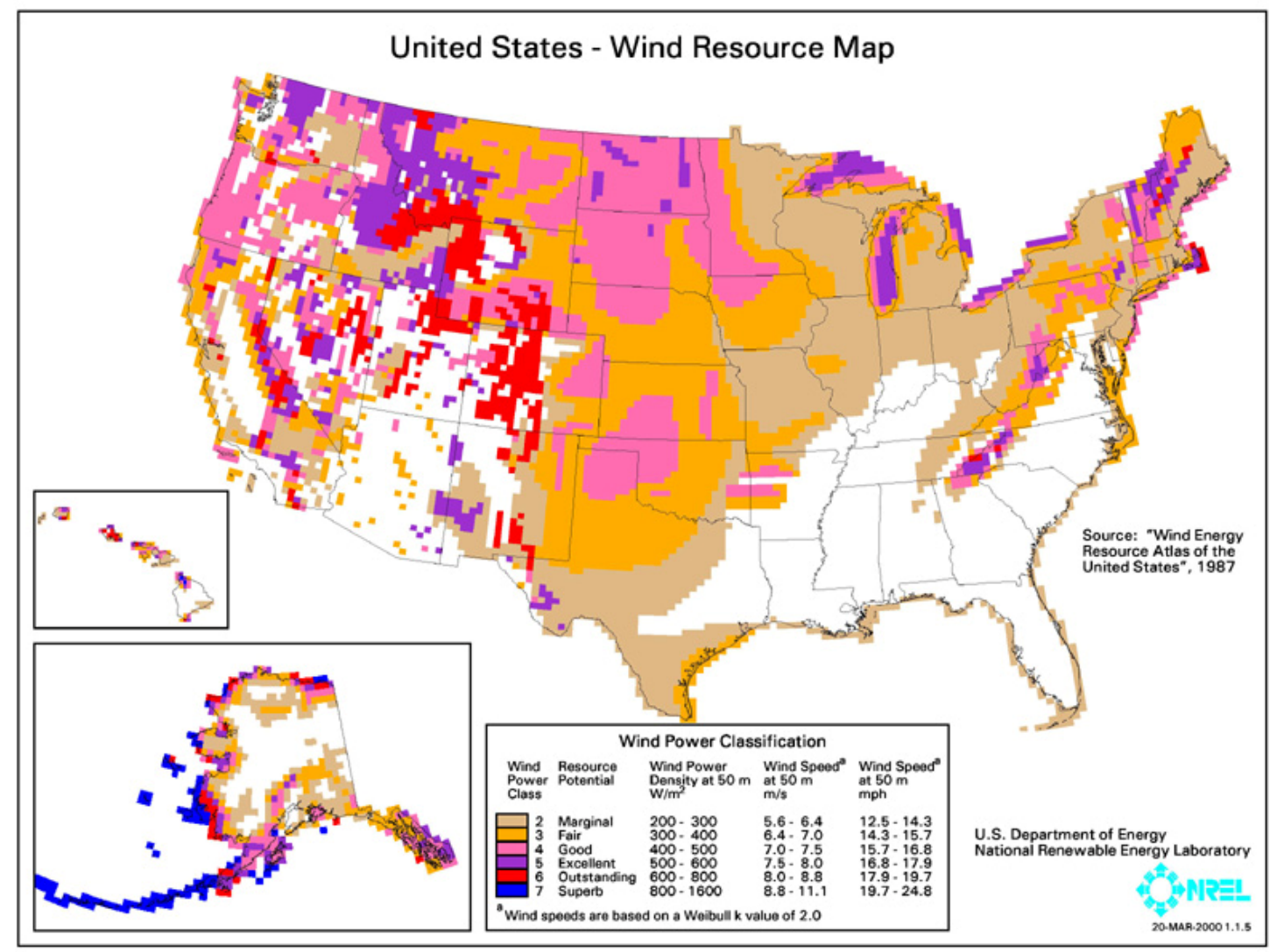

Fig. 1. U. S. wind resource map. 


\subsubsection{Wind Energy Technologies}

Wind energy presently provides about $1 \%$ of the electrical power-generating capability in the United States. However, the Wind Energy Association reports that wind-produced electrical power is increasing at about 20\% per year and can be expected to provide about 6\% of the nation's electrical power by 2020 . Research advances in the last 20 years have dramatically reduced the cost of wind-produced energy.

There are two basic designs of wind turbines: the vertical-axis (egg-beater) and the horizontal-axis (propeller). Horizontal-axis wind turbines are the most common U.S. designs and are the ones most commonly used by electrical power providers. The turbines sit high atop towers, or masts, so they can take advantage of the stronger, less turbulent winds 30 meters or higher above the earth's surface.

Wind turbine systems can be used as stand-alone power generators or can be connected to a utility power grid. Stand-alone turbines are typically used for water pumping or generating electricity for single homes and farms. For utility power generation, a large number of turbines are usually built close together to form a wind farm.

\subsubsection{Uses of copper in wind energy technologies}

The primary use of copper in wind energy technologies is in the coil windings in the stator and rotor portions of the generator, in the high-voltage power cable conductors (Fig. 2), and in the transformer coils. Copper is vital to the electrical grounding system for wind turbine farms. ${ }^{1}$ The turbine masts are prime attractors of lightning strikes, so they require a lightning protection system. When lightning strikes a turbine blade, the current passes along the blade, through the blade hub in the nacelle (gearbox/ generator enclosure) and down the mast to a grounding system. The blade incorporates a large cross-section copper conductor that runs along

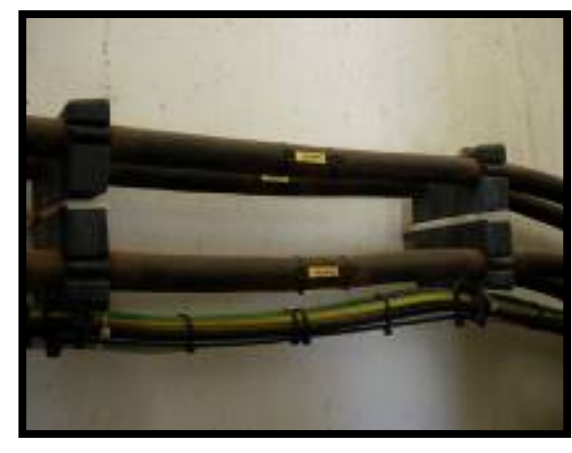

Fig. 2. Copper conductors in wind tower. its length and allows the current to pass along the blade without deleterious heating effects. The nacelle is protected by a lightning conductor, often copper. The grounding system $^{2}$ (Fig. 3) at the base of the mast consists of a thick copper ring conductor bonded to the base or located within a meter of the base. The ring is attached to two diametrically opposed points on the mast base. Copper leads extend outward from the ring and connect to copper or copper-clad grounding electrodes. The grounding rings at all turbines in the wind farm are inter-connected, providing a networked system with an extremely small aggregate resistance.

According to the American Wind Energy Association

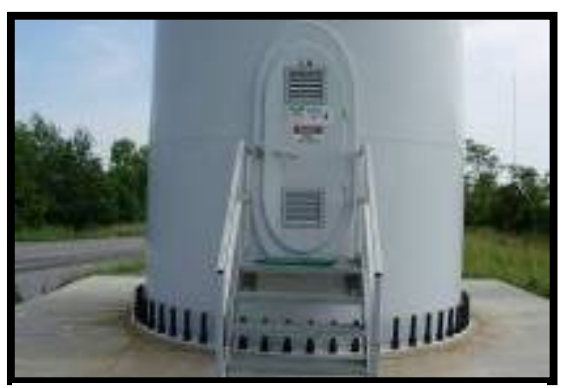

Fig. 3. Wind tower base. (AWEA), all wind farms have numerous features in common, ${ }^{3}$ including a single turbine with a connection to a generator and a step-up transformer, and medium-voltage collector system, and interconnect equipment.

1 Copper and Wind Energy: Partners for a clean environment, Copper Development Association publication A6101-XX/05, available at www.copper.org.

2 Renewable Energy 2000: Issues and Trends, DOE/EIA-0628, p. 22, Energy Information Administration, Office of Coal, Nuclear, Electric and Alternate Fuels, U.S. Department of Energy

Washington, DC,

3 AWEA Electrical Guide to Utility Scale Wind Turbines, March 2005. 
Analysis of TVA's Buffalo Mountain Wind Farm. ${ }^{4}$ The Tennessee Valley Authority's Buffalo Mountain Wind Farm (Fig. 4) has two types of turbines. For the Vesta V47, a 660-kW turbine, the windings in the system total approximately $800 \mathrm{lb}$ in copper windings. There are three of these turbines. Three 2/0 cables each $270 \mathrm{ft}$ long connect the generator at the top of the tower to the controller below. Approximately $100 \mathrm{lb}$ of copper busing are located at the base. In addition, the control cabinet contains about $300 \mathrm{lb}$ of various small gauge wires. Each tower has a grounding system that consists of a $1 / 0$

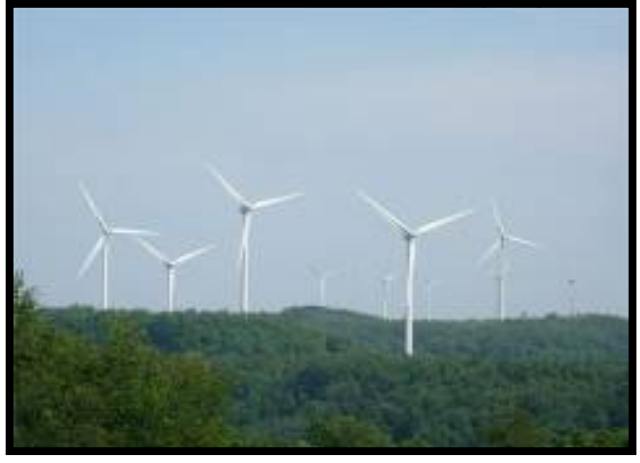

Fig. 4. TVA's Buffalo Mountain Wind Farm. copper cable that runs the length of the tower. Several circular rings of this cable surround the tower. The base of the tower is about $39 \mathrm{ft}$. Three $20 \mathrm{ft}$ long copper grounding rods, about 1/2" in diameter are associated with each tower.

There are 15 V80 turbines rated at $1.8 \mathrm{MW}$ each. The cable connection is $4 / 0$. The transfer cabinet contains about 15 lb of copper. From the transfer cabinet either $2 / 0$ or $3 / 0$ cable conveys the energy underground to a switch yard or collection point. From there, aluminum overhead transmission cable distributes the energy away from the farm.

Analysis of Sweetwater Wind Farm. An analysis of copper used at the Sweetwater II Wind Farm in Texas is described at the CDA website. A considerable amount of large diameter copper cable is used (see Fig. 5). The cable connecting the turbine, which runs the length of the tower, contains the largest fraction. There is also a significant amount of copper in the grounding system and connections from the individual towers to junction stations. There are also many miles of high voltage aluminum cable that contain some copper.

\subsubsection{Forecast for Wind Energy Technology}

Sweetwater II

61 Turbines - 91.5 MW

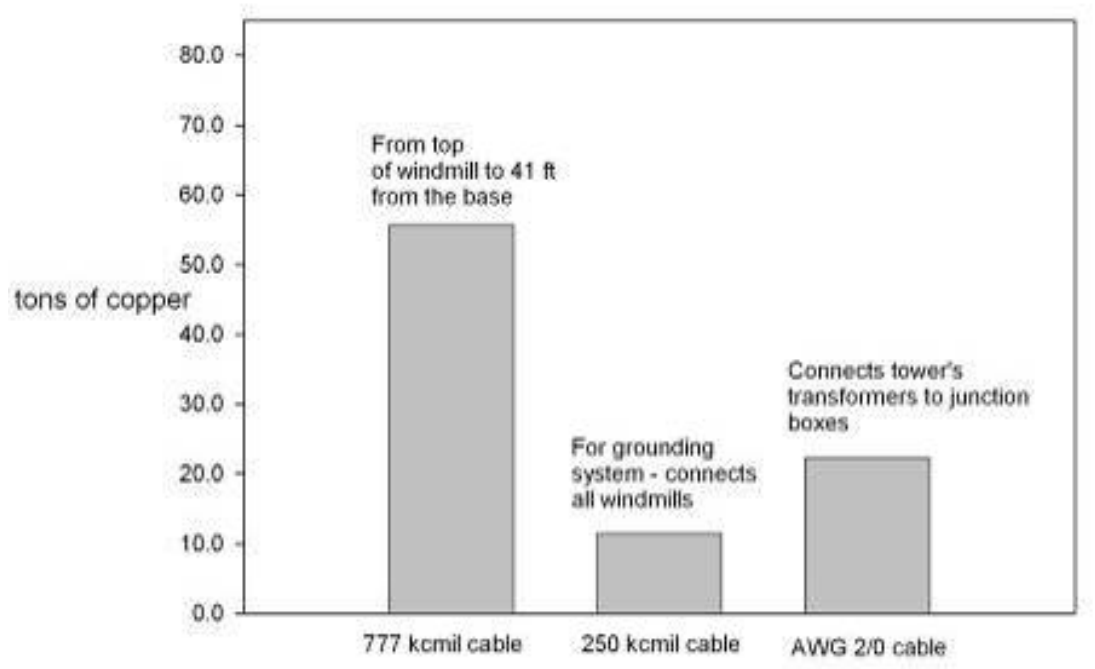

Fig. 5. Wind energy copper use (Sweetwater Wind Farm).

4 Tennessee Valley Authority Buffalo Mountain Wind Power Development Project - U. S. Department of Energy - EPRI Wind Turbine Verification Program, EPRI Report No. 1004207, March 2003. 
"There is considerable uncertainty about the growth potential of wind power, which depends on a variety of factors, including fossil fuel costs, State renewable energy programs, technology improvements, access to transmission grids, public concerns about environmental and other impacts, and the future of Federal production tax credits.” (AEO p. 81)

The AEO, because of these uncertainties, shows a leveling of capacity following a near-term rapid increase. Figure 6 illustrates this. If the key assumptions are relaxed and a reduction of cost and production of $10 \%$ is assumed, then the AEO predicts a 15 percent increase over the base case for 2030. The reason for this leveling is that the EIA cannot assume for the projections that the energy tax credits will be extended past Dec 2007. Other projections are more optimistic for wind. The AWEA predicts about a factor of 20 at ten years out and continuing the rapid rate.

EPRI predicts a factor-of-three increase over the next three years. One of the obstacles to wind energy at the moment is turbine availability. Suppliers are booked for the next 2-3 years.

The section on wind energy showed a wide variation in projections between the Energy Outlook and the American Wind Energy Association. Nonetheless, it is

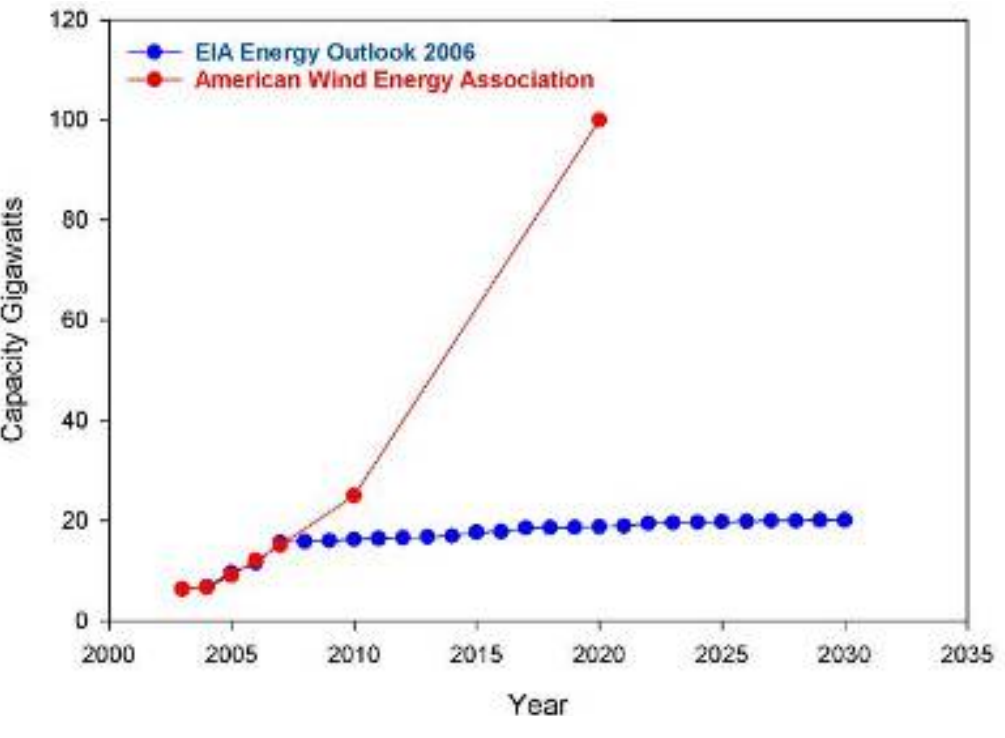

Fig. 6. Wind Energy Association projection. apparent that growth will be rapid in the near term. The information cited above for the Sweetwater and Buffalo Mountain Wind Farms allows for an estimate of projected copper usage. The discussion of the Sweetwater installation showed that with respect to cabling, according to the three categories, approximately 88 tons of copper was used for the 91-MW facility. Thus, about 1 ton of copper for every MW is required (see Fig.7.) The Buffalo wind farm data was specific about copper wiring in the turbine and at other locations. When scaled for the amount of power produced, it turns out that such wiring contributes about 1 ton of copper per MW. Thus, it appears that about 2 tons of copper is required per MW of wind energy

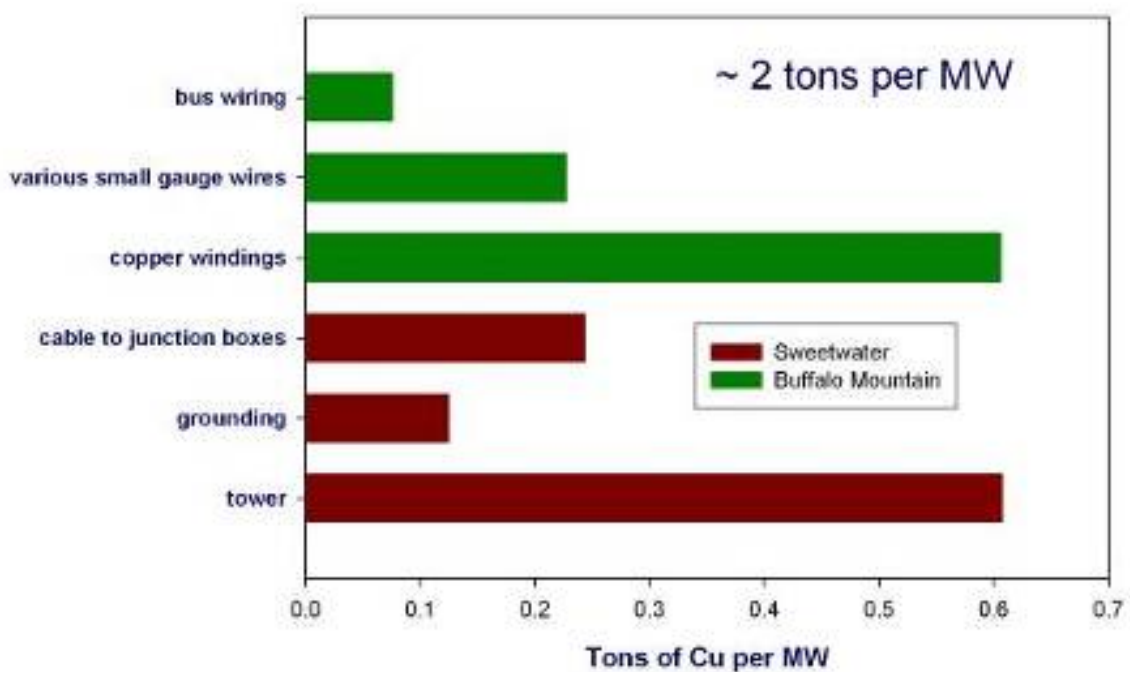

Figure 7. Copper cable tonnage distribution. production based upon these two installations. 
Near-term growth is about $2 \mathrm{GW}$ per year. This would require, under the present assumptions, 4000 tons per year. Thus, depending on how typical these two wind farms are with respect to copper, thousands of tons could be needed in future years. NREL recently published a $20 \%$ wind energy scenario (Fig. 8) that geographically depicts wind energy generation.

\subsection{GEOTHERMAL}

Geothermal energy technologies are based on the extraction of heat from thermal reservoirs in the Earth. These thermal reservoirs range in location from the uppermost 3 meters of the Earth's surface to the hot water and hot rock present a few kilometers below the Earth's surface to the extremely hot, molten rock (magma) that flows deep in the Earth's crust. In the U.S., most geothermal reservoirs of hot water are in the western states, Alaska, and Hawaii. This section on geothermal energy is divided into two parts. The first is a discussion of making use of the earth's thermal reservoir for heat pump and direct heating. In this case, no electricity is generated as the energy is directly used. The second discussion is of geothermal power generation.

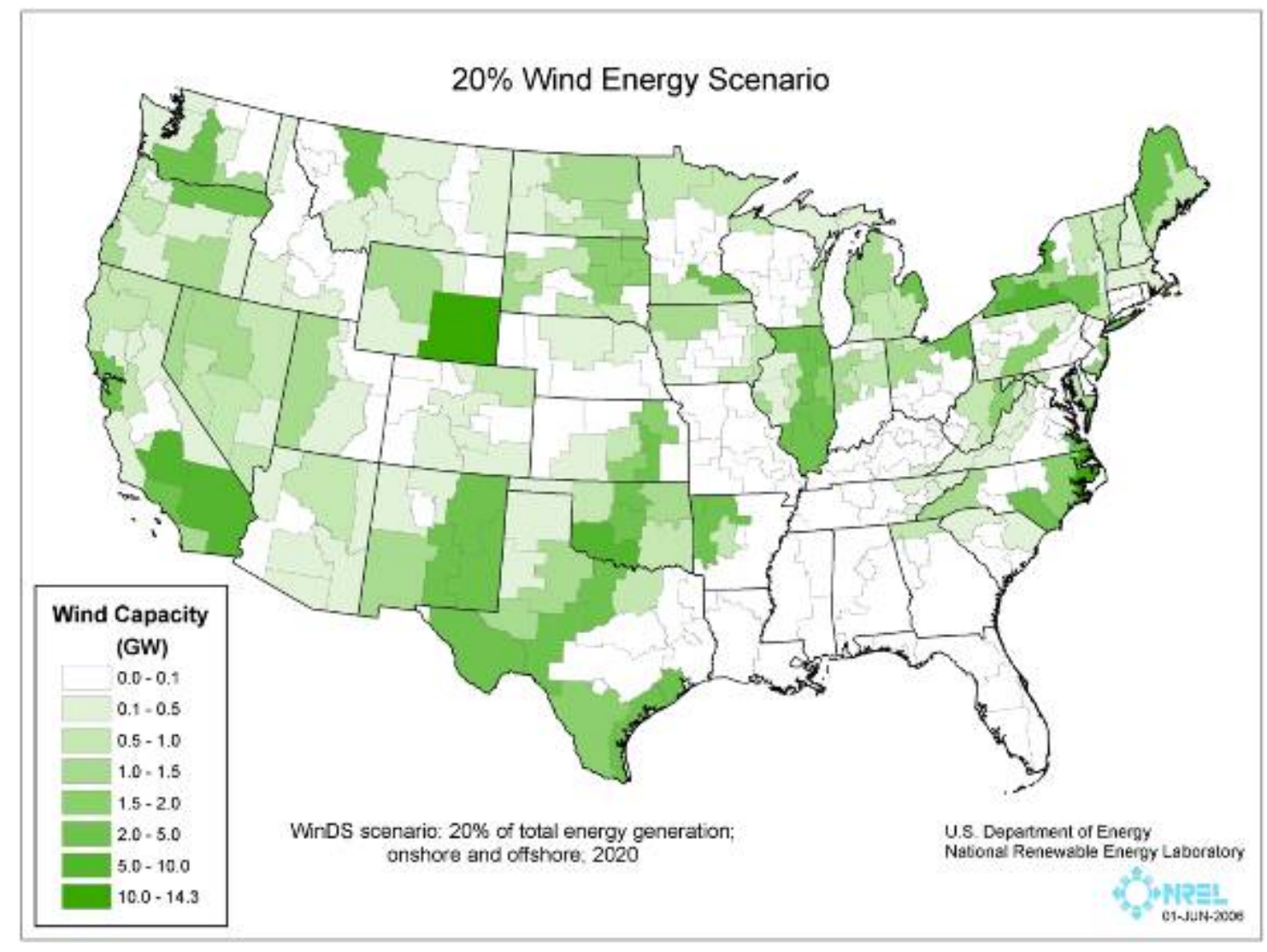

Fig. 8. Twenty percent wind energy scenario.

\subsubsection{Geothermal Heat Pump Technologies ${ }^{5}$}

The ground 3 meters beneath the surface maintains a nearly constant 10 to $15{ }^{\circ} \mathrm{C}$ temperature, yearround. Geothermal heat pump systems can extract heat from this reservoir-or dump heat into it— to heat

5 The discussion at http://www.eere.doe.gov/RE/geothermal.html is a good source of additional information. 
and cool buildings. " ${ }^{6}$ "A geothermal heat pump system consists of pipes buried in the shallow ground near the building, a heat exchanger, and ductwork into the building. In winter, heat from the relatively warmer ground goes through the heat exchanger into the house. In summer, hot air from the house is pulled through the heat exchanger into the relatively cooler ground. Heat removed during the summer can be used as no-cost energy to heat water.",

Another variation is called geothermal direct-use. For this, hot water extracted from just below the surface is useful for heating buildings and greenhouses, providing moderate heat for drying crops and performing industrial processes, and supplying warm water for fisheries. The hot water is pumped into large holding tanks or ponds for distribution of hot water to boilers, for heat transfer to closed-loop systems via plate heat exchangers, or for pre-heating domestic hot water (DHW). In the case of DHW, the water is stored in and flows through copper pipes that are immersed in the tanks or ponds. If the preheating does not raise the DHW to the desired temperature, then a conventional boiler can be used to attain the final heating. Resorts/spas and fish farming are the fastest growing sectors for this.

Hot dry rock resources occur at depths of 3 to 5 miles everywhere beneath the Earth's surface and at lesser depths in certain areas. Access to these resources involves injecting cold water down one well, circulating it through hot fractured rock, and drawing off the heated water from another well. Currently, there are no commercial applications of this technology. Existing technology also does not yet allow recovery of heat directly from magma, the very deep and most powerful resource of geothermal energy (Fig. 9). Figure 10 shows temperature data across the U. S. at a depth of $6 \mathrm{~km}$; these data indicate that the western region is more advantageous for accessing higher temperatures.

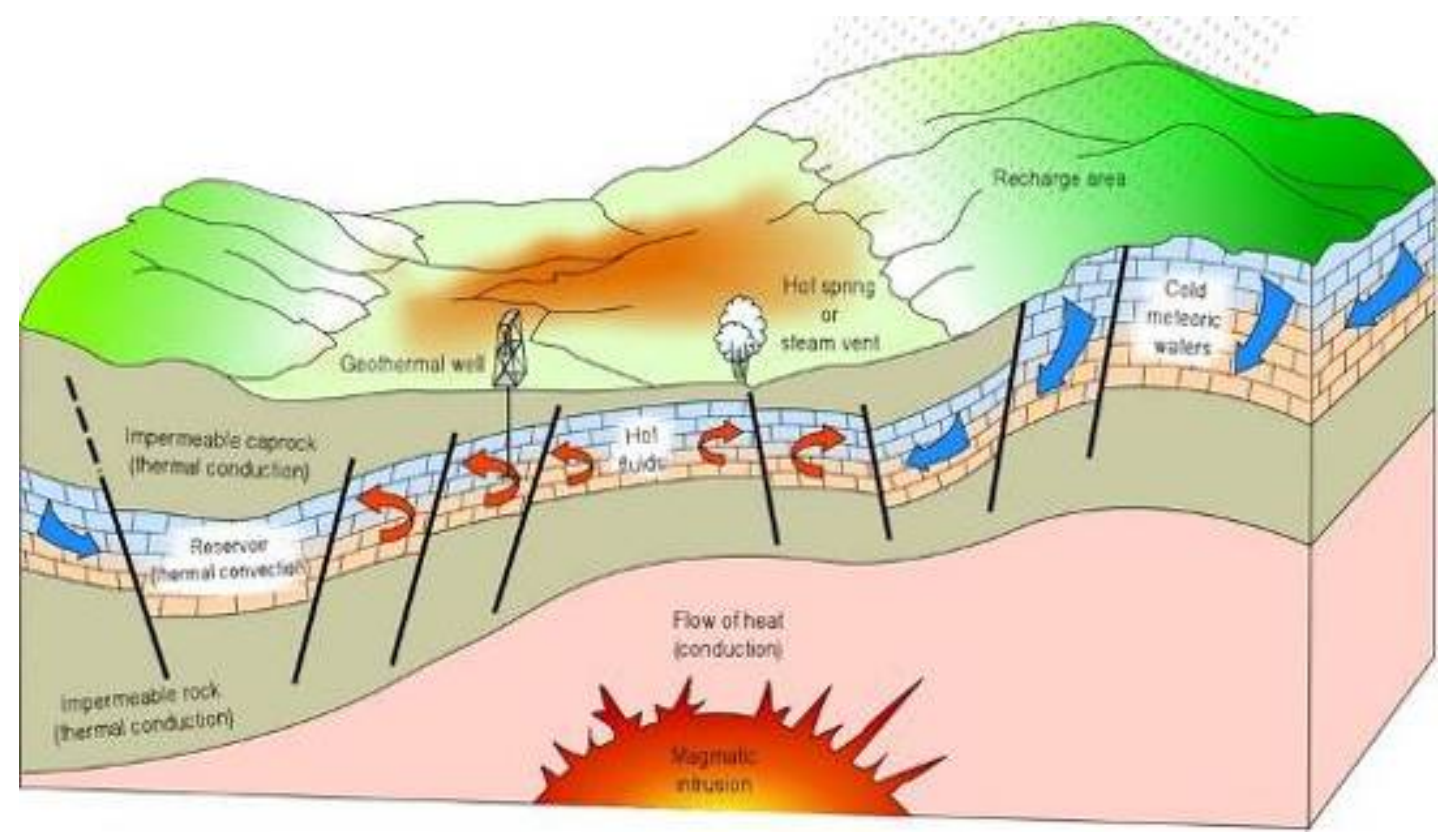

Fig. 9. Hot dry rock technology.

\subsubsection{Uses of Copper in Geothermal Energy Heat Pump Technologies}

Conventional closed-loop geothermal heat pump systems extract or eliminate heat through a heat-

6 See discussion on geothermal heat pumps at http://www.energystar.gov/.

7 http://www1.eere.energy.gov/geothermal/overview.html\#heat_pump 
exchanger that is in thermal contact with a water-based solution. A pump circulates the solution through an underground loop of HDPE piping. In an improved geothermal heat pump system design, termed the direct exchange (DX) method, ${ }^{8}$ the HDPE piping is replaced by one or more loops of copper piping and the water-based solution is replaced by a liquid refrigerant. The copper piping enables very efficient heat transfer between the refrigerant and the ground, and the heat pump operation is consequently more efficient in the copper-piping system than it is in the HDPE-piping system. The increased efficiency of this design results in an energy savings of about 50\% over that of an air-source heat pump system.

DX heat pumps use significant amounts of copper piping and are an alternative to water-source heat pumps. There are currently two U. S. manufacturers. DX heat pumps require neither water/antifreeze solution nor an extra pump with its associated heat exchanger; they tend to be more efficient and use less piping; and the piping is smaller bore (a possible advantage where space is limited).

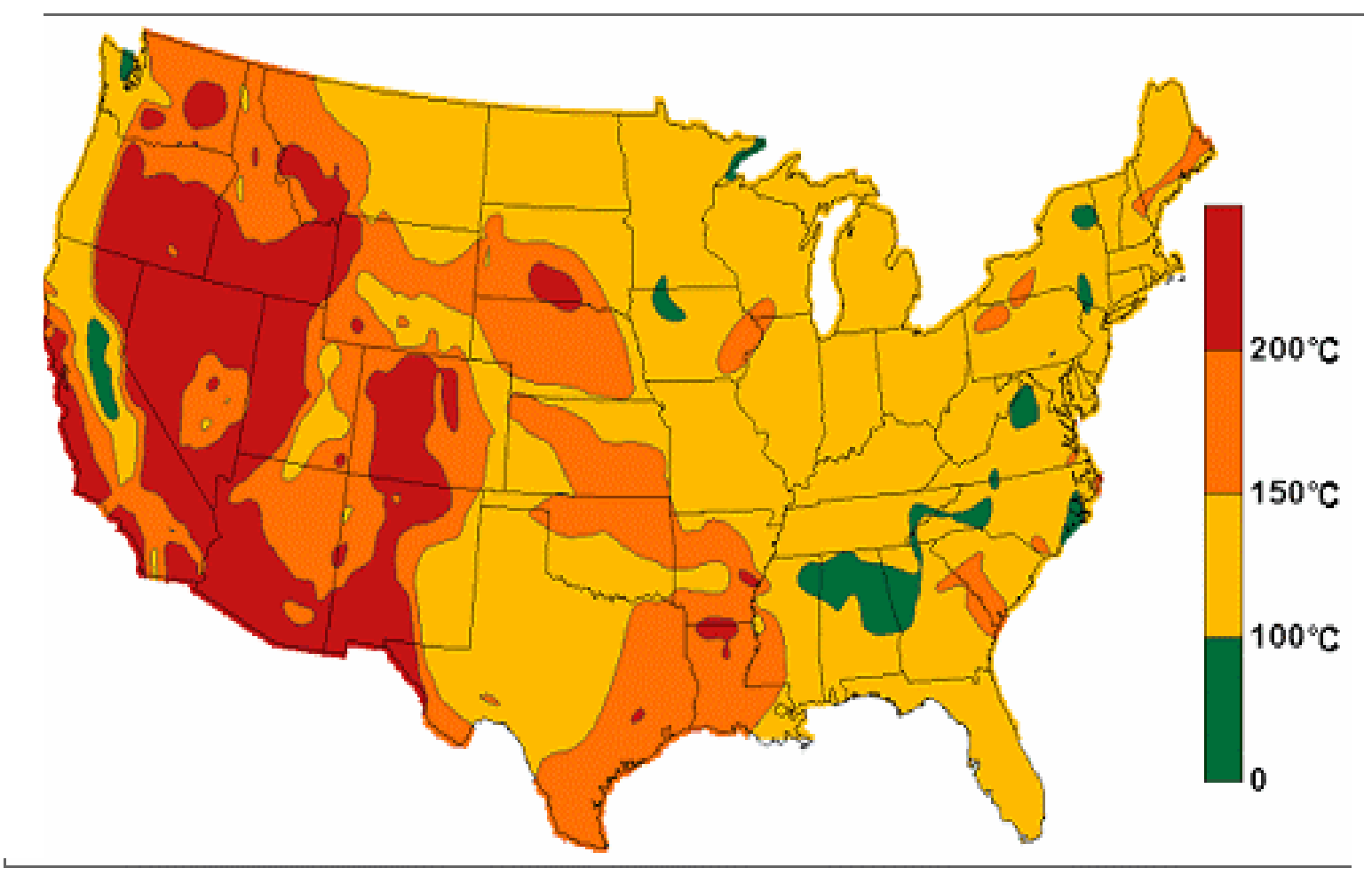

Fig. 10. Temperatures at 6-km below ground surface.

In one design, three loops of copper tubing are used per ton of capacity. A loop consists of a pair of copper pipes, $1 / 4$ in. and 3/8 in., extending $100 \mathrm{ft}$ into the ground and back for a total of $200 \mathrm{ft}$. Other designs use more loops but of shorter length. The number of tons for an installation can vary. In Tennessee, a 5000 sq. ft. home may be sized with a three ton system and would therefore have 9 loops totaling $1800 \mathrm{ft}$ of each size piping. In addition, there is about $16 \mathrm{ft}$ each of copper tubing in the two manifolds to which the loops connect. A different example obtained from TecHomebuilder magazine ${ }^{9}$ described a three-ton system for a 3200 sq. $\mathrm{ft}$. house. A $3800 \mathrm{ft}^{2}$ residence in California was fitted with 3-

8 Direct Exchange Geoexchange Systems Making Inroads in California, GHPC \#CS-096, Geothermal Heat Pump Consortium, Columbia, MD, February 2004.

${ }^{9}$ http://www.techomebuilder.com/article/4466.html Oct/Nov 2005. 
ton and 3.5- ton systems. ${ }^{10}$ To determine the right size of a system for a given facility, the proper calculations must be performed. ${ }^{11}$

A perceived disadvantage of

DX systems relates to the durability of the copper in some soil types. In some early systems, galvanic action in high $\mathrm{pH}$ soils caused corrosion of the metal. This is solved by some manufacturers by applying a thin coating to the copper. Another approach is to use a sacrificial rod inserted into the soil. The rod can be replaced every 5 or 10 years, if needed. It turns out that ECR typically drills a hole of about 3” diameter. The space surrounding the much smaller pair of copper pipes is then filled with sand or grout. The thermal properties of these materials are advantageous to the process and it eliminates the corrosion problem. Another impediment to DX has

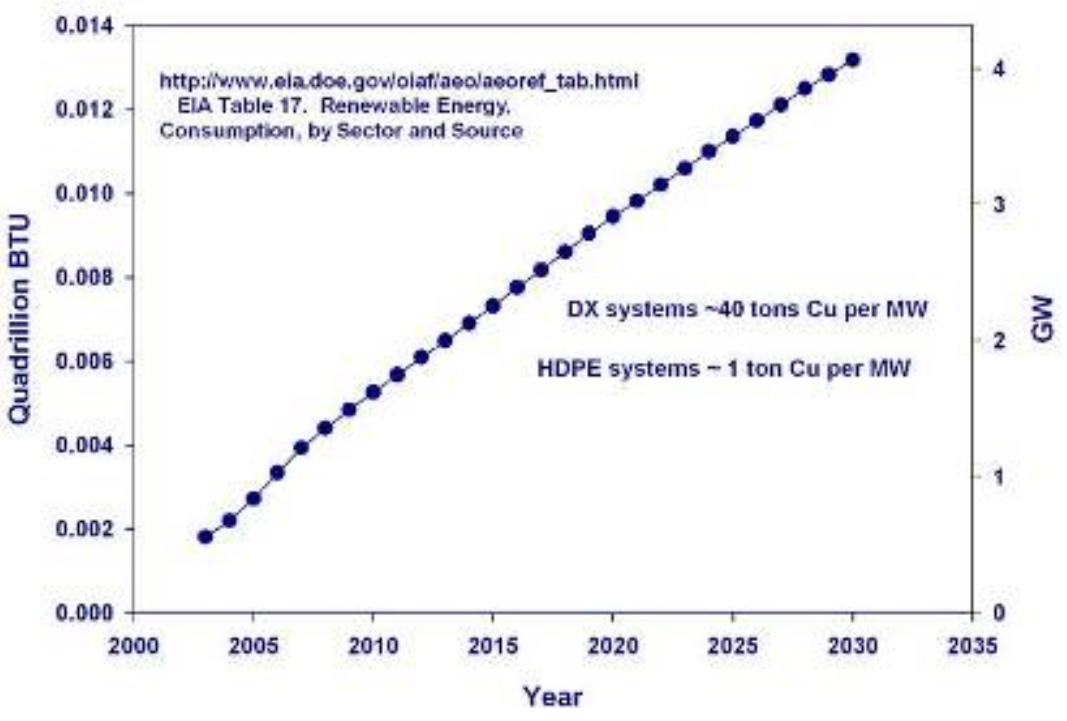

Fig. 11. Geothermal heat pump projections. been lack of experience and knowledge on the part of HVAC installers. For instance, how to effect the drilling has not been a part of their usual skill set. This is readily addressed by direct-exchange system representatives.

The section on ground source heat pumps (GSHPs) gave an example system consisting of $600 \mathrm{ft}$ each of 1/4- and 3/8-in. copper tubing per ton of heat pump capacity for a DX system. This corresponds to about $250 \mathrm{lb}$ of copper. If it is assumed that the average installation is 3 tons (more or less), then such a DX system will involve $750 \mathrm{lb}$ (0.38 tons). It was also stated that approximately 80,000 GSHP units were sold in the most recent year. If the number of DX units ranges from $2 \%$ to $5 \%$, then the corresponding amount of copper necessary would range from 600 to 1500 tons.

Non-DX units also contain some copper. One estimate we received was $20 \mathrm{lb}$. If $95 \%$ of the non-DX units contain this amount of copper, the total is 750 tons. As depicted in Fig. 11, the Energy Outlook projection is for a $7 \%$ per year growth.

In closing, it may be noted that President George W. Bush has had a geothermal heat pump installed on his Texas ranch. It is a vertical closed loop system that reportedly cuts his costs for heating and cooling by $40 \% .^{12}$

\footnotetext{
${ }^{10} \underline{\text { http://www.ecrtech.com/content/interior.asp?section=news\&body=bland_NEWS_article.htm }}$

${ }^{11}$ http://www.hvacwebtech.com/sizing.htm

${ }^{12}$ Geothermal (Ground-Source) Heat Pumps-A World Overview. GHC Bulletin Sept 2004. J. Lund, et al Geo-Heat Center, Oregon Institute of Technology, Klamath Falls, Oregon, USA
} 


\subsubsection{GSHPs in the U.S ${ }^{13}$}

The following relevant points concerning GSHPs come from a presentation by M. Ally to the International Energy Agency:

- Geothermal heat pump market growth (from 0 terrajoule/year in 1975 to almost 20,000 TJ/year in 2005)

- Geothermal direct-use sectors and growth (highest for resorts/spas and fish farming)

- Recent annual sales information (vertical systems: 36,800; horizontal systems: 30,400)

- Barriers to technology (cost, contractor performance, lack of certification programs)

- Incentive programs in various states (22 states offer GSHP incentive programs)

- Current field studies are ongoing at the ORNL Habitat for Humanity site in Lenoir City, Tennessee

- Geothermal energy represents $\sim 0.32 \%$ of total energy consumption by all energy sources in the United States.

- The largest use of geothermal energy is in electric power production ( 2500 MWe).

- Direct-use/electricity generation projects are primarily in the western United States.

- Geothermal heat pumps extend the utilization of geothermal energy to all 50 states.

- There are 30 geothermal equipment manufacturers in the United States.

- Yearly sales of geothermal heat pumps are 80,000 units (46\% vertical closed loop systems; 38\% horizontal closed loop systems; $15 \%$ open loop systems).

- The main barrier to use of geothermal heat pump technology is the installation cost.

- $\quad$ About 22 states offer incentive programs.

In contrast to Europe and Japan, where residential GSHP for a 250-m2 home would typically cost US $\$ 14,000$, the United States is trying to develop technologies for which the installed cost would be marginally greater than the cost of an existing air-to-air heat pump. The goal of R\&D in the United States is to develop a SWS-GSHP that would cost approximately $20 \%$ more than an air-to-air heat pump sized for an affordable home. Such a system would be very different from and more economical than the current horizontal or vertical loop systems being used in Europe and Japan.

\subsubsection{ARI310 Systems}

ARI 310 systems use a tremendous amount of copper in the condenser and evaporator of the heat exchanger. The copper tubing is something like 3/8" in diameter and $100 \mathrm{ft}$ long. There are about 2 million units sold to date and about $10 \%$ of existing units are being replaced (8 year lifespan depending on location) every year owing to the fact of their incessant usage in commercial applications such as motels.

\subsubsection{Geothermal Energy Power Generation}

Geothermal power plants utilize wells that penetrate geothermal reservoirs and pipe closed-loop water to the reservoirs to manufacture steam for turbines or, if the water temperature is below the boiling point, to exchange heat with a lower-boiling-point fluid that vaporizes and drives a turbine. Although

\footnotetext{
${ }^{13}$ From a presentation made by ORNL staff member M. Ally to International Energy Agency Annex 29 Workshop in Linz, Austria, May 2006.
} 
substantial growth is predicted for geothermal energy electricity production, it is predicted to be gradual for the next five years, Fig. 12. The average to 2030 is $4.5 \%$ growth. However, recent conversations with EIA indicate these projections may be revised considerably downward. The growth may be as little as $1 \frac{1 / 2}{2}$ GW over this period. An announcement on this near the end of calendar year 2006 is expected. The resources for this type of energy are limited to the western United States and no new plants are projected.

\subsection{BIOMASS}

Biomass energy technologies are based on the use of organic matter such as vegetation, microbiological organisms, and animal remains for energy production and utilization. Mankind has used wood for thousands of years to provide bioenergy in the form of heat. Today, cultivated plants, agricultural and forestry product residues, and the organic portions of municipal and industrial wastes are providing heat for power and are being synthesized to produce chemicals and fuels for transportation. In the future a large fraction of our biomass resources may be obtained through the cultivation of energy crops such as fast-growing trees and grasses. Cultivated biomass is generally referred to

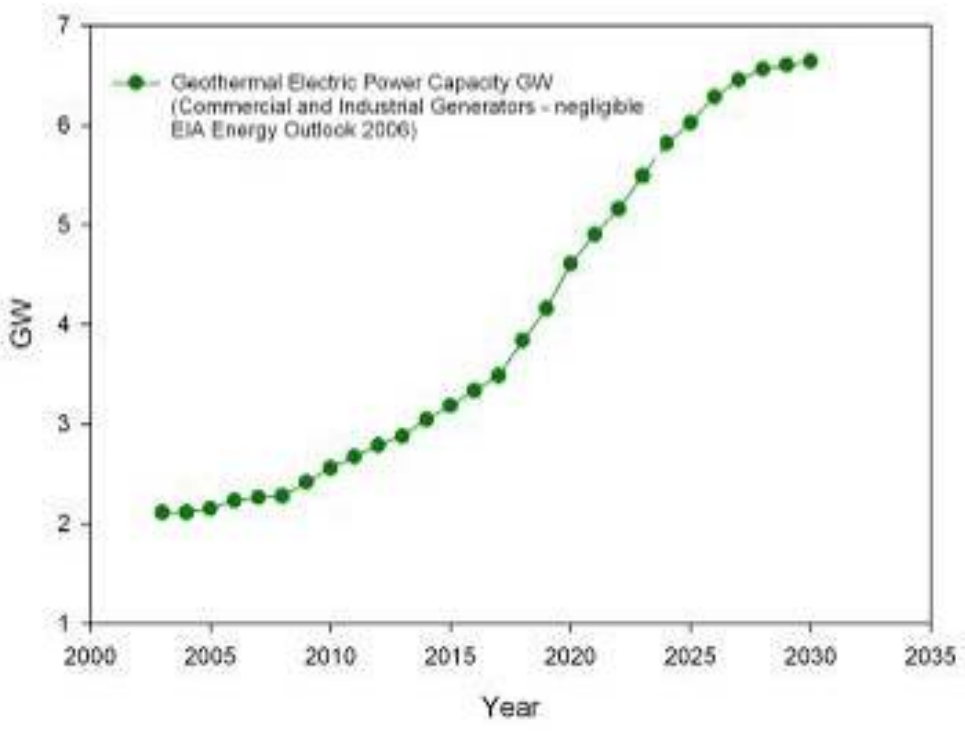

Fig. 12. Electricity from renewable sources: geothermal. Source: EIA Energy Outlook 2006.

as a feedstock. Biomass energy sources are second to hydropower sources in renewable energy production in the U.S., accounting for approximately three percent of our primary energy production.

\subsubsection{Biomass Technologies ${ }^{14}$}

Biomass can be burned to produce steam for electricity generating turbines or to heat boilers used in manufacturing processes. Biomass-based direct-combustion electricity generation technologies are wellestablished in the U.S., with a power capacity of 10 gigawatts at present.

Biomass can be converted to fuel oil by the application of heat, and this oil can be substituted for petroleum-based fuel oils. Methane gas (natural gas) is produced by decaying biomass in sanitary landfills, and it can be captured for use in electricity generation or for industrial processes.

Biomass is a unique among the renewable energy sources because it can be converted into liquid fuels for transportation, ethanol and biodiesel being the two most common and commercially viable biofuels. Ethanol (ethyl alcohol) is produced through the fermentation of a carbohydrate-rich biomass such as corn. Biodiesel is an ester refined from vegetable oils, animal fats, algae, or even recycled cooking greases. Biodiesel can be blended with petroleum-based diesel (the so-called B20 diesel) and used in conventional diesel engines or it can be used undiluted in specially modified engines. In both cases, the use of biodiesel results in fewer noxious vehicle emissions.

For the production of electricity by biomass systems, DOE divides the technology into four primary classes: ${ }^{15}$

\footnotetext{
${ }^{14}$ The discussion at http://www.eere.doe.gov/RE/biomass.html is a good source for additional information.

${ }^{15}$ http://www1.eere.energy.gov/biomass/electrical_power.html
} 
- $\quad$ direct-fired - similar to fossil-fuel power plants usually smaller

- co-fired - substitutes biomass for coal in existing plants

- gasification - involves heating biomass to make flammable gas

- modular systems - employ some of the same technologies mentioned above, but on a smaller scale that is more applicable to villages, farms, and small industry.

\subsubsection{Uses of Copper in Biomass Energy Technologies}

Direct combustion and co-firing use the existing power generation infrastructure. However, two growth areas that use copper fall under the categories of gasification and small modular systems. Both areas require turbines to generate electricity, and of course, copper wiring and windings are important components in these turbines.

Case Study: Modular Biomass Systems. Biomass electrical energy/thermal production, also known as cogeneration (the production of electricity and thermal energy simultaneously from a common fuel source). Modular power plants can improve power quality on weak transmission lines located far from central transmission plants. Potential opportunities for modular biomass power plants would be sawmills with kilns or food processing plants with high-energy crops and stockpiles of offal (cornhusks, rice hulls, etc.). Biomass combustion is considered $\mathrm{CO}_{2}$ neutral and therefore not a major producer of greenhouse gas linked to climate change. Neither is it a major contributor of acid rain due to negligible sulphuric outputs.

Economics of wood waste energy generation become more attractive as traditional fuel prices increase. Generated locally, biomass-generated money stays in the local economy. A value-added product is realized by the collection, processing, and transporting of woody biomass. This is more labor intensive than fossil fuel delivery, thus creating a direct economic impact on local employment and having an indirect economic impact throughout the local economy. Biomass cogeneration systems, and in particular small (less than $5 \mathrm{~mW}$ ) modular biomass cogeneration systems, can fit in nicely and very efficiently within the energy makeup of many communities, small or large, rural or urban. They can make a serious difference in the costs of electrical power, "clean” waste disposal, and thermal energy (steam, hot water, absorption chilling, etc.) when properly designed, installed, and maintained.

The following represent typical future commercial customers of biomass.

- U.S. Army

- Small wood-working companies

- Nut and tree fruit processing companies

- Buildings/greenhouses with gas-fired boilers

- Lumber processing/drying companies currently using natural gas/propane

- Off-grid homeowners

- Utilities

- Farms and farmer cooperatives

- Biofuels research organizations

- Most of the future customers listed have the potential to accumulate biomass residues on-site, thereby eliminating collection and transportation costs.

Stirling Power, LLC. The generator portion of the STM PowerUnit is a standard GE product. The copper used in installation would be for the conductors tying into the building or utility circuit and is the same as with any other generator of comparable size (and is often aluminum instead) and depends on 
distances. The specifications shown are for a 55-kW Model 260 PowerUnit burning low-BTU biogas (400-650 BTU/scf) in a CHP configuration.

A Stirling engine and induction generator set. This is a 55-kW (electrical) generator set for combined heat and power applications. The total enclosure length is about 2.5 meters, and this assembly has a mass of about $1300 \mathrm{~kg}$ (Fig. 13).

At the right side is the combustion chamber and heat exchanger. The fourcylinder regenerative Stirling engine is adjacent to the combustor, with the swash-plate drive housing obscured by the center post of the enclosure. At the left of the picture is a 55-kW induction motor used as a generator and to start the Stirling engine.

Below the induction generator terminal box (black cable going to left) is an electrolyzer used to replenish the

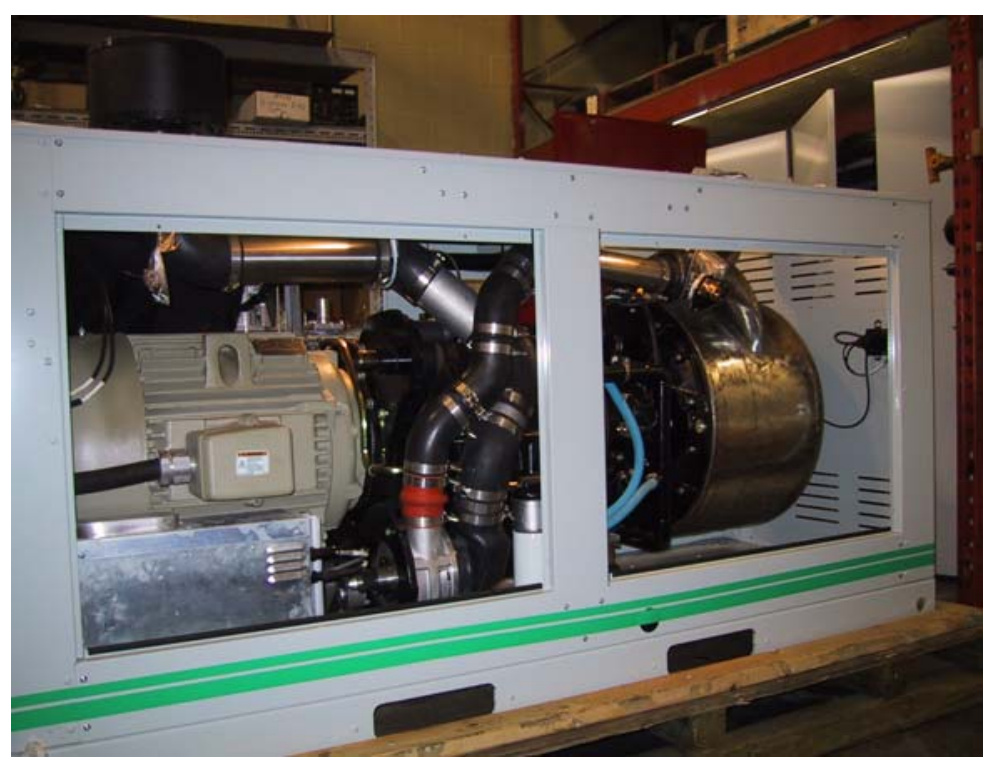

Fig. 13. Modular Stirling engine biomass system. hydrogen gas working fluid of the engine. To the right of the electrolyzer is a small blower to force combustion air into the burner assembly. The blue hoses circulate cooling water through the cool-side heat exchanger - a hose connection point for cooling water is just above at the right end of the induction generator.

The Stirling engine/generator set shown here is made by STM Power Inc. and is intended for auxiliary power and heat production at large farms, or for plants that produce waste flammable oils. This engine can be adapted to run on low-heat-value landfill gas or biofuel digester gas.

Small modular systems are a part of DOE research. ${ }^{16}$ Such systems "fulfill the great market potential for distributed, on site, electric power and heat generation throughout the world."17

Lastly, an exciting development in biomass conversion technologies is the use of copper-based and copper-activated catalysts for improved conversion reactions. ${ }^{18}$ There are numerous patented formulations of copper-stabilized metal catalysts for improved methane and hydrogen gasification from wet biomass. The production of hydrogen from biomass-derived methanol is of intense research interest, and copper-based catalysts are showing promise in producing hydrogen at lower temperatures in a variety of pathways. Copper-containing catalysts have shown excellent conversion efficiencies in decomposing methanol to hydrogen. ${ }^{19}$ A fixed-bed reactor with nickel-copper-chromium activated $\alpha-\mathrm{Al}_{2} \mathrm{O}_{3}$ has been shown to steam-reform ethanol. ${ }^{20}$ A nickel-promoted copper-zinc-cement catalyst was highly active in

\footnotetext{
${ }^{16}$ Small Modular Biomass Systems, DOE-GO-102000-1057.

${ }^{17}$ http://www1.eere.energy.gov/biomass/small_modular_gasification.html

${ }^{18}$ T. A. Milne, C. C. Elam, and R. J. Evans, Hydrogen from Biomass: State of the Art and Research Challenges, IEA/H2/TR-02/001, pp. 20-22, National Renewable Energy Laboratory, Golden, CO.

${ }^{19}$ Ibid, p. 20.

${ }^{20}$ Ibid, p. 22.
} 
the thermal decomposition of methanol in a water-methanol equimolar mixture. ${ }^{21}$

\subsubsection{Forecast for Biomass}

Future efficiency improvements will include co-firing of biomass in existing coal fired boilers and the introduction of high-efficiency gasification combined-cycle systems, fuel cell systems, and modular systems. Already, biomass ranks second to hydropower in energy production. The EIA tracks biomass for electricity generation in 3 categories:

Municipal Solid Waste (MSW): There are four components: recycling, composting, landfilling, and waste-to-energy via incineration. Waste-to-energy combustion and landfill gas are byproducts of municipal solid waste. ${ }^{22}$

Wood/Wood Waste: Wood comes primarily from U.S. forestland, as well as private land clearing and landscaping. Waste wood comes from manufacturing and wood process wastes and construction/ demolition. $^{23}$

Landfill Gas: Municipal solid waste contains significant portions of organic materials that produce a variety of gaseous products when dumped, compacted, and covered in landfills. Anaerobic bacteria thrive in the oxygen-free environment, resulting in the decomposition of the organic materials and the production of primarily carbon dioxide and methane. Landfill gas energy facilities capture the methane (the principal component of natural gas) and combust it for energy. ${ }^{24}$

Figure 14 is a map of U. S. Biomass resources. Figure 15 shows the growth in using wood, landfill gas, and the use of small modular biomass burning systems. It appears that this segment of the biomass market could in the future promote the market for electricity generating turbines, which in turn require copper in their manufacture. This category involves producing electricity with turbines and engine-based generators that will incorporate copper. The development of new biomass technologies will pave the way for the production of biochemicals and biomaterials currently being produced from petroleum.

\footnotetext{
${ }^{21}$ Ibid, p. 20.

${ }^{22}$ http://www.eia.doe.gov/cneaf/solar.renewables/page/mswaste/msw.html

${ }^{23}$ http://www.eia.doe.gov/cneaf/solar.renewables/page/wood/wood.html

${ }^{24}$ http://www.eia.doe.gov/cneaf/solar.renewables/page/landfillgas/landfillgas.html
} 


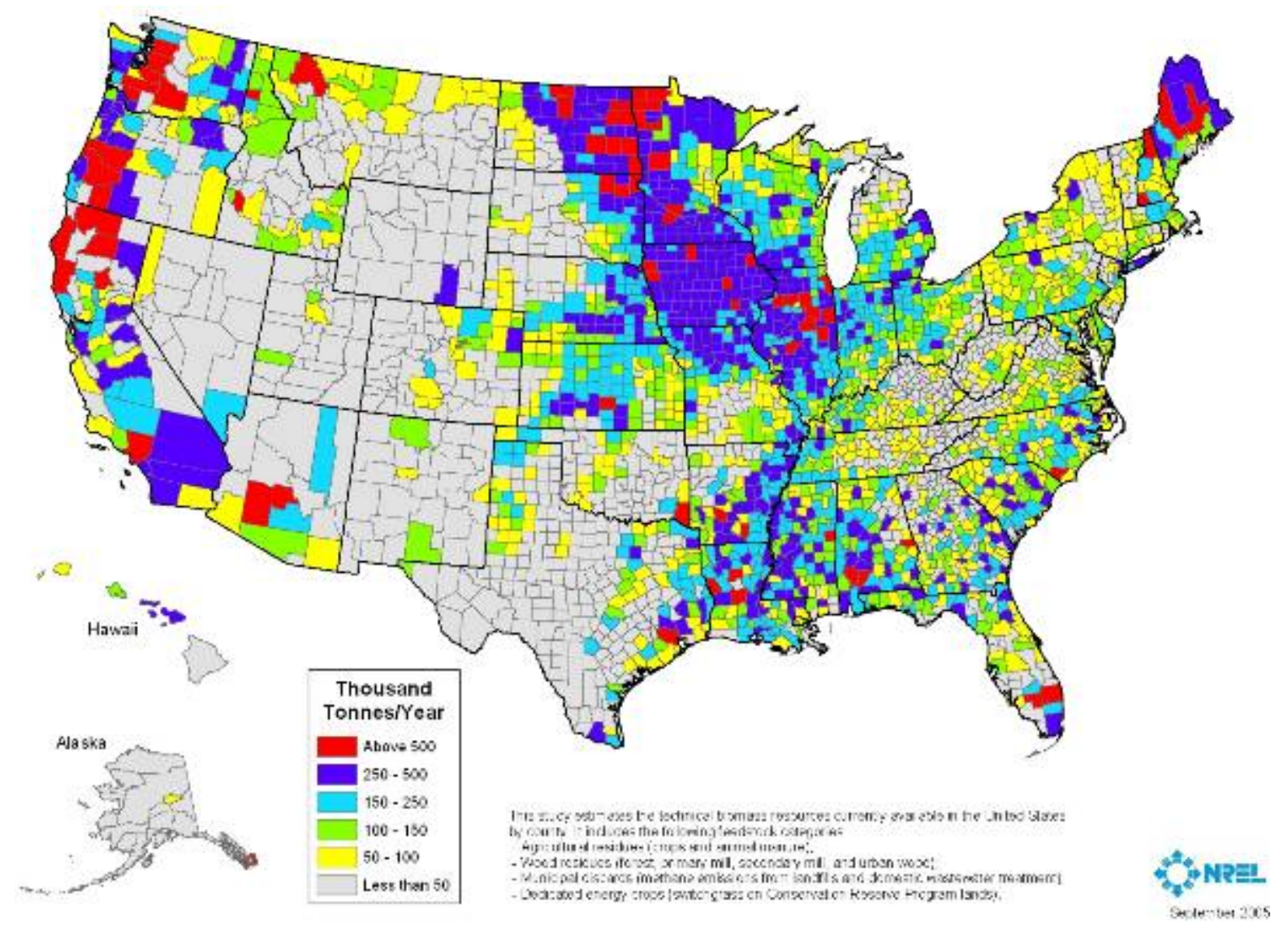

Fig. 14. U. S. Biomass resources.

The term biomass covers a wide variety of activities. Some activities appear not to use significant copper, for instance ethanol production. Sometimes biomass merely substitutes for coal in an existing plant. However, the category cited by the Energy Outlook report under the term "Wood and Other Biomass" refers to situations that will call for small generator systems to convert landfill gas and other biomass into electricity. Various techniques and equipment can be used to accomplish this. Currently, there are no estimates for the amount of copper used in turbines associated with biomass electricity production. For a rough estimate, we can use the $660-\mathrm{kW}$ generator at TVA's Buffalo Mountain Wind farm, which employs 800 lbs of copper. If used to represent all turbines, then approximately 0.6 tons of copper is required per MW of power generated. However, to our knowledge, hard data on the ratio of added capacity using new generators to cogeneration, which does

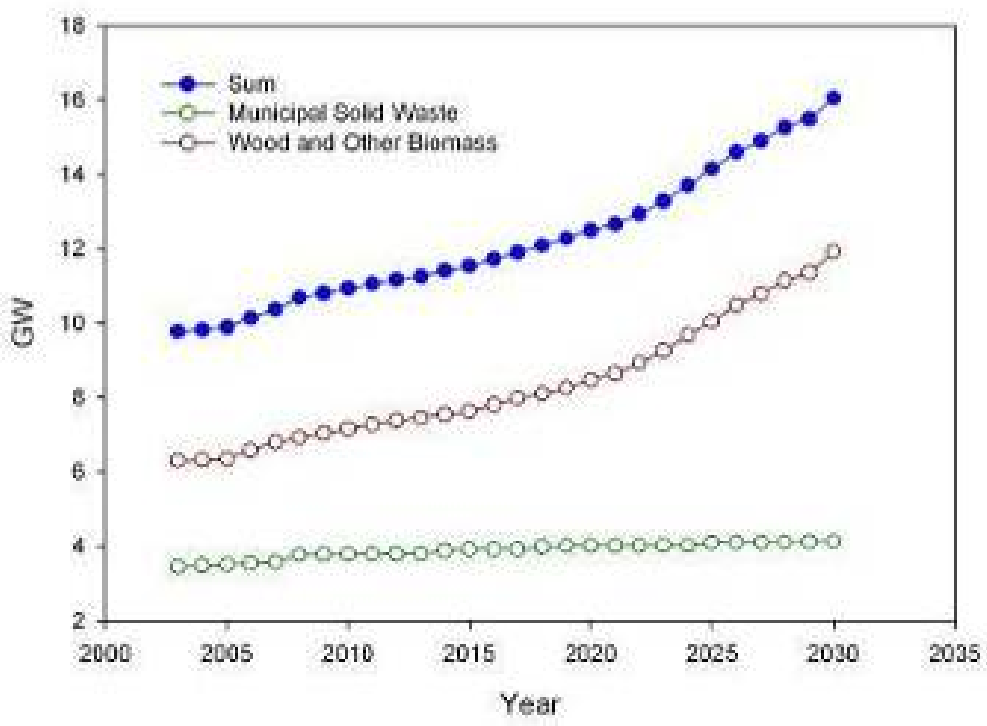

Fig. 15. Biomass projections. not use added copper, is unavailable. 


\subsection{SOLAR}

Solar energy is the oldest renewable energy source from both a cosmological and historical context. Solar energy utilization has benefited building methods for centuries, but it has become of increasing interest in developed countries as the environmental costs and limited supply of fossil-fuel energy sources become more critical. The rate at which solar radiation reaches a unit of area in space in the region of the Earth's orbit is $1366 \mathrm{~W} / \mathrm{m}^{2}$. Of the energy incident on the Earth, approximately $19 \%$ is absorbed by the atmosphere, and clouds reflect approximately 35\%. The generally accepted value of the normal solar radiation at sea level about $1000 \mathrm{~W} / \mathrm{m}^{2}$, but the average irradiance is lower. In North America the average power of the solar radiation lies somewhere between 125 and $375 \mathrm{~W} / \mathrm{m}^{2}$, with solar power between 3 and $9-\mathrm{kWh} / \mathrm{m}^{2} /$ day. Figure 16 shows a map of the solar flux across the United States; Fig. 17 is a close up of the Southwest where the solar flux tends to be the highest.

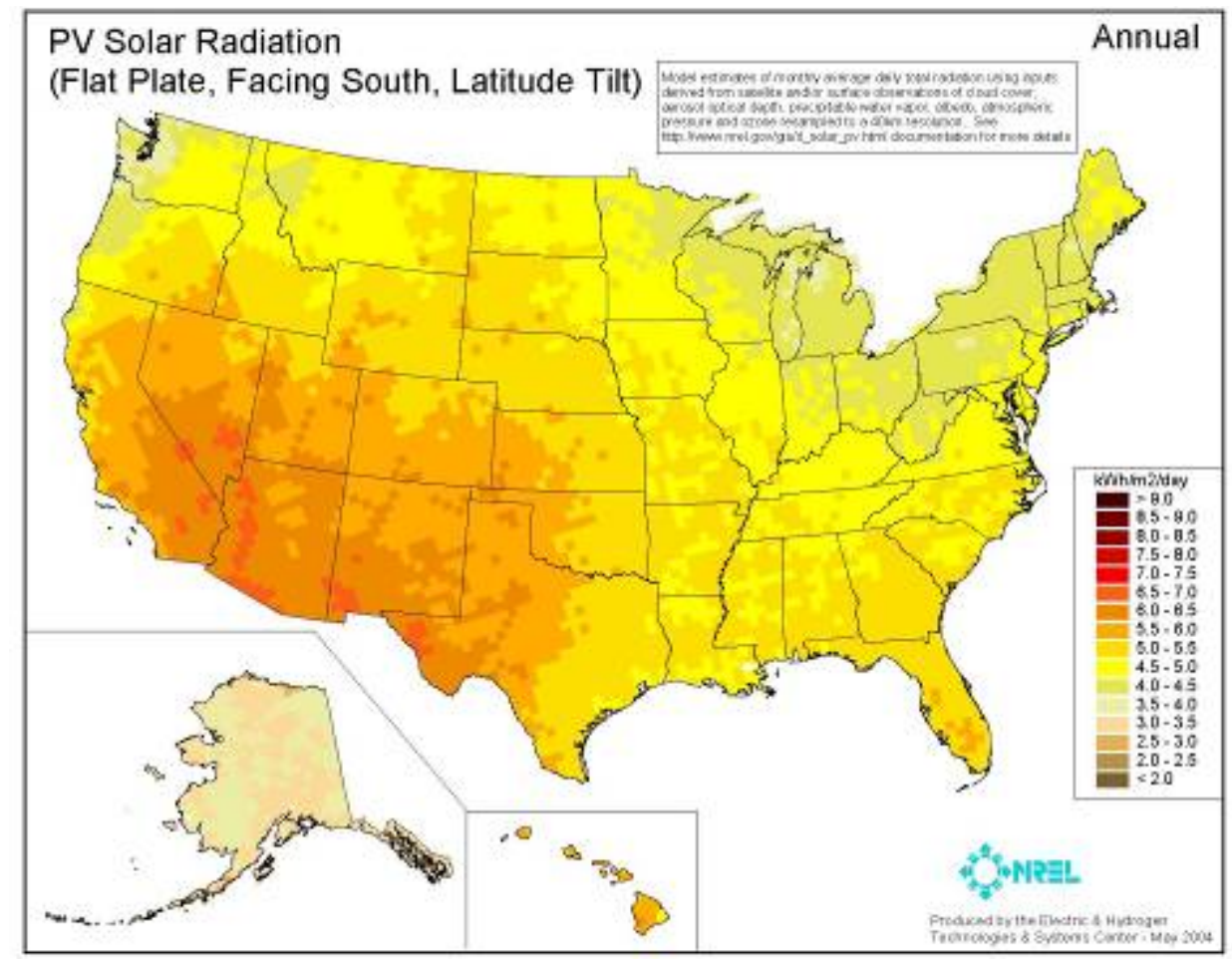

Fig. 16. Solar map of the United States.

\subsubsection{Solar Energy Technologies ${ }^{25}$}

There is a wide range of technologies that use solar energy. Commercial applications concentrate solar power, photovoltaics, solar heating, and solar lighting. Concentrated solar power (CSP) plants generate electric power by using mirrors to concentrate the solar energy and create high temperatures in materials. A CSP generation plant consists of two systems: one to collect solar energy and convert it to heat energy and one to convert the heat energy to electricity. In the United States, the CSP electrical generation capacity is about $350 \mathrm{~mW}$. One plant went on-line recently in Arizona $(1 \mathrm{~mW})$ and ground has been broken for a new plant in Nevada $(64 \mathrm{~mW})$. The others have been in operation for more than 15

\footnotetext{
${ }^{25}$ The discussion at http://www.eere.doe.gov/RE/solar.html is a good source of additional information.
} 


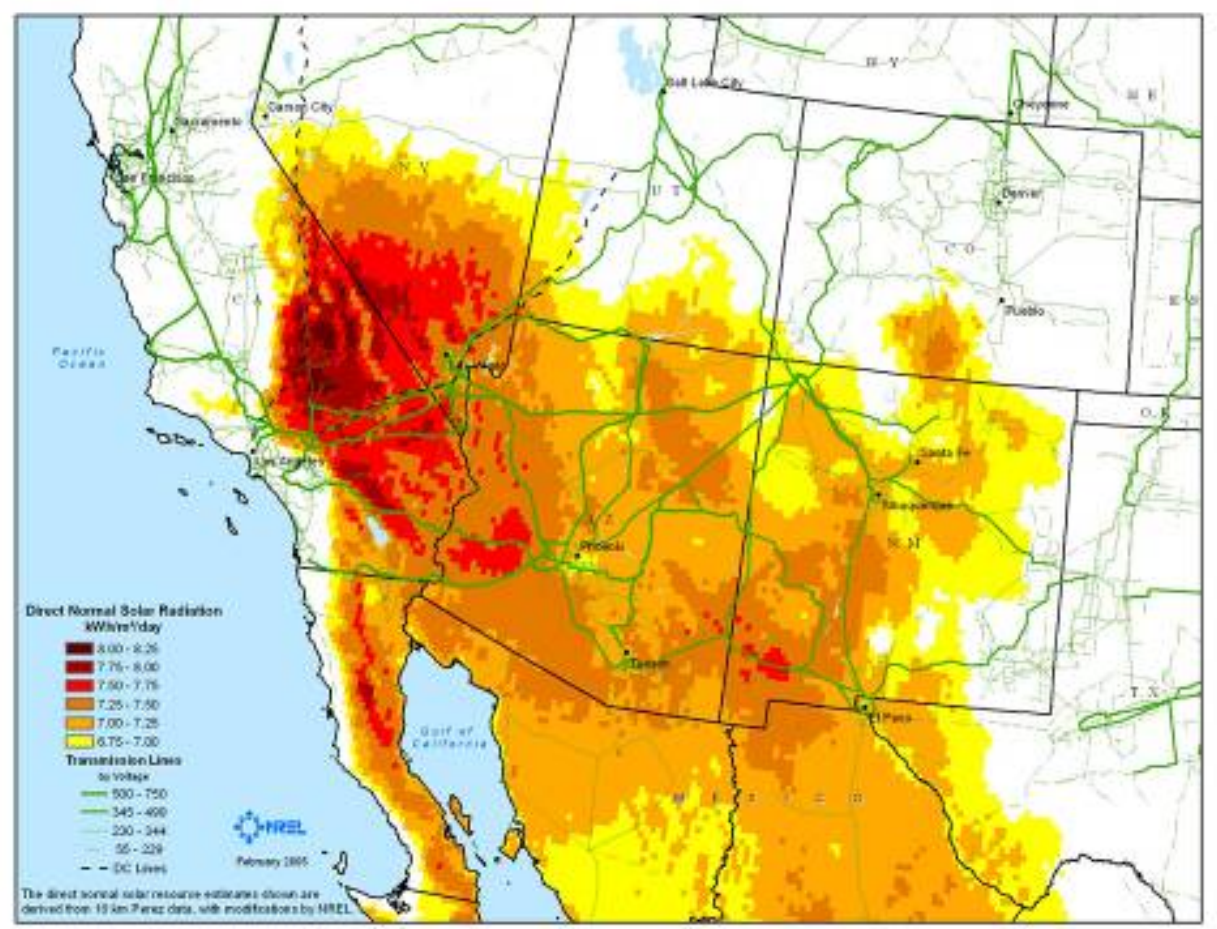

Fig. 17. Southwestern Solar Resources.

years. CSP generation systems can be small — some CSP systems pump heat into a thermal reservoir to allow power generation at night or during times when the solar radiation is insufficiently intense.

Photovoltaic (PV or solar cell) systems convert sunlight directly into electricity. A PV cell consists of a semiconducting material that absorbs photons at certain wavelengths of sunlight. The energy in the absorbed photons releases electrons within the semiconductor, and when the semiconductor is configured to allow the electrons to flow it, the solar energy is converted to electrical energy. To make a useful electrical power generating system, PV cells must be combined into modules that hold about 40 cells, and these modules are then mounted in arrays. These PV arrays can generate electricity for a single building or, if combined in very large numbers, for a power plant.

Solar lighting is simply the use of natural sunlight to light a building or supplement its artificial lighting system. Passive solar lighting, where buildings are designed to utilize available sunlight, has been around for a long time. Hybrid solar lighting is a recent technological advancement where sunlight is concentrated and piped through large diameter optical fibers into buildings where it is combined with electric light in "hybrid" light fixtures. Sensors keep the room at a steady lighting level sensing the brightness and adjusting the intensity of artificial lighting as necessary. Hybrid solar lighting pipes sunlight directly to the light fixture and no energy conversions are necessary, making the system one the most efficient solar energy technologies.

Solar hot water heaters use the sun to heat either water or a heat-transfer fluid in collectors. A typical system will might reduce the need for conventional water heating by about two-thirds. High-temperature solar water heaters can provide energy-efficient hot water and hot water heat for large commercial and industrial facilities. 


\subsubsection{Use of copper in solar energy technologies - Photovoltaics}

There are several types of solar collectors. Most consist of a flat copper plate, painted black that has water tubes attached to the absorber plate. As solar energy falls on the copper plate and is absorbed, the energy is transferred to water flowing in the tubes. The absorber plate is mounted in a casing that has a clear covering and insulation to protect the absorber plate from heat loss.

To meet growing demand for PV systems, an estimated $250 \mathrm{~mW}$ of new manufacturing capacity is being installed in the United States, Japan, and Germany. ${ }^{26}$ This new capacity will make devices that are based new thin film materials, such as copper indium diselenide (CIS). The current world-record thin-film solar cell efficiency of $17.7 \%$ is held by a device based on copper indium diselenide. Breaking the \$2-per-watt manufacturing cost barrier for PV modules within the decade will require additional advancements in high-efficiency thin films (e.g., CIS) and the construction of "next generation" production volume manufacturing facilities. ${ }^{27}$

\subsubsection{Use of copper in solar energy technologies-photothermal}

There are numerous small businesses in the solar thermal industry segment with widely varying approaches. Two such companies, for example, that use significant amounts of copper are Schuco and Sunenergy.

Schuco is a retailer of solar thermal collectors (Figs. 18 and 19) that contain a copper absorber plate with copper serpentine piping behind the plate. Pre-insulated piping connects the thermal collectors (placed on a roof) to a hot water tank. However, copper is used only in the wiring and the concentrated PC container base and tracker motors for a total of $1.5 \mathrm{~kg}$ of copper per $125-\mathrm{W}$ unit.

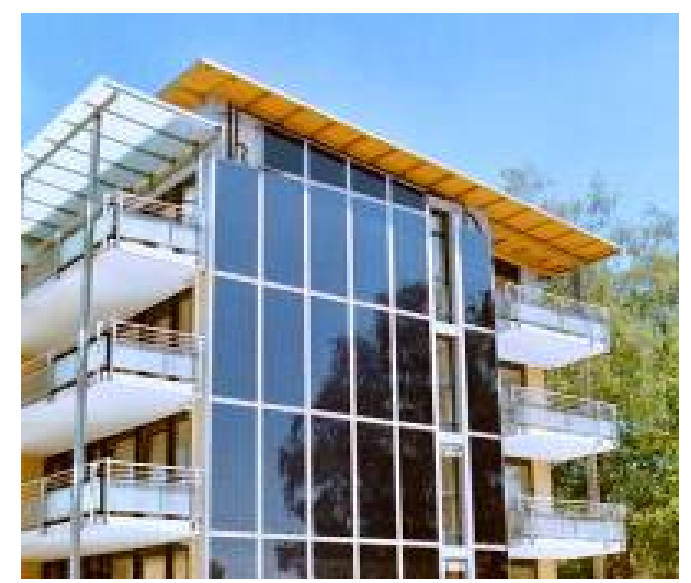

Fig. 18. Large-scale installation.

Source: Schuco Solar Thermal.

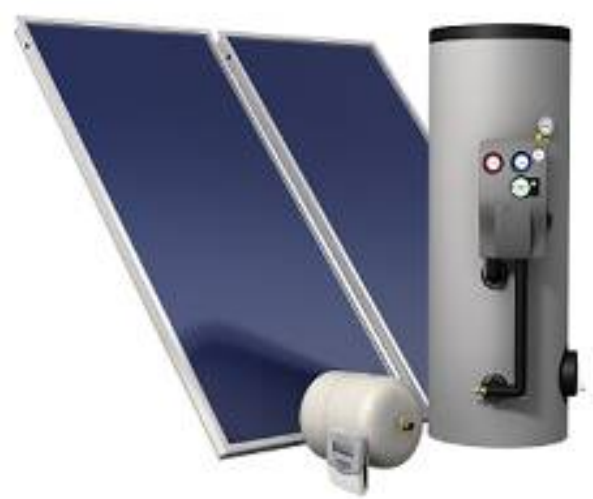

Fig. 19. Schuco unit.

${ }^{26}$ Renewable Energy 2000: Issues and Trends, DOE/EIA-0628, p. 22, Energy Information Administration, Office of Coal, Nuclear, Electric and Alternate Fuels, U.S. Department of Energy, Washington, DC, http://www.eia.doe.gov/cneaf/solar.renewables/rea_issues/rea_issues_sum.html

${ }^{27}$ Ibid, p. 25. 


\subsubsection{Types of Solar Thermal Collectors}

Solar collectors heat a fluid, either air or liquid. The different types of collectors are below:

Flat-Plate Collectors. Flat-plate collectors are the most common collector for residential waterheating and space-heating installations. A typical flat-plate collector is an insulated metal box with a glass or plastic cover — called the glazing — and a dark-colored absorber plate. The glazing can be transparent or translucent. Translucent, low-iron glass is a common glazing material for flat-plate collectors because low-iron glass transmits a high percentage of the total available solar energy. The glazing allows the light to strike the absorber plate but reduces the amount of heat that can escape. The sides and bottom of the collector are usually insulated, further minimizing heat loss. The absorber plate is usually black because dark colors absorb more solar energy than light colors. Sunlight passes through the glazing and strikes the absorber plate, which heats up, changing solar radiation into heat energy. The heat is transferred to the air or liquid passing through the collector. Absorber plates are commonly covered with "selective coatings," which retain the absorbed sunlight better and are more durable than ordinary black paint. Absorber plates are often made of metal - usually copper or aluminum - because they are both good heat conductors. Copper is more expensive, but is a better conductor and is less prone to corrosion than aluminum. Flatplate collectors fall into two basic categories: liquid and air, and both types can be either glazed or unglazed.

Liquid collectors. In a liquid collector, solar energy heats a liquid as it flows through tubes in or adjacent to the absorber plate. For this type of collector, the flow tubes are attached to the absorber plate so the heat absorbed by the absorber plate is readily conducted to the liquid. The flow tubes can be routed in parallel, using inlet and outlet headers, or in a serpentine pattern. A serpentine pattern eliminates the possibility of header leaks and ensures uniform flow. A serpentine pattern is not appropriate, however, for systems that must drain for freeze protection because the curved flow passages will not drain completely. The simplest liquid systems use potable household water, which is heated as it passes directly through the collector and then flows to the house to be used for bathing, laundry, etc. This design is known as an "open-loop" (or "direct") system. In areas where freezing temperatures are common, however, liquid collectors must drain the water either when the temperature drops or use an antifreeze type of heattransfer fluid. In systems with heat-transfer fluids, the transfer fluid absorbs heat from the collector and then passes through a heat exchanger. The heat exchanger, which generally is in the water storage tank inside the house, transfers heat to the water. Such designs are called "closed loop" (or "indirect") systems. Glazed liquid collectors are used for heating household water and sometimes for space heating. Unglazed liquid collectors are commonly used to heat water for swimming pools. Because these collectors need not withstand high temperatures, they can use less expensive materials such as plastic or rubber. They also do not require freeze proofing because swimming pools are generally used only in warm weather.

Air Collectors. Air collectors are simple, flat-plate collectors used primarily for space heating. The absorber plates in air collectors can be metal sheets, layers of screen, or nonmetallic materials. The air flows past the absorber by natural convection or when forced by a fan. Because air conducts heat much less readily than liquid does, less heat is transferred between the air and the absorber than in a liquid collector. In some solar air-heating systems, fins or corrugations on the absorber are used to increase air turbulence and improve heat transfer. The disadvantage of this strategy is that it can also increase the amount of power needed for fans and, thus, increase the costs of operating the system. In colder climates, the air is routed between the absorber plate and the back insulation to reduce heat loss through the glazing. However, if the air will not be heated more than $30^{\circ} \mathrm{F}\left(17^{\circ} \mathrm{C}\right)$ above the outdoor temperature, the air can flow on both sides of the absorber plate without sacrificing efficiency. Air systems have the advantage of eliminating the freezing and boiling problems associated with liquid systems. Although leaks are harder to detect and plug in an air system, they are also less troublesome than leaks in a liquid system. Air systems can often use less expensive materials, such as plastic glazing, because their operating temperatures are usually lower than those of liquid collectors. 
Evacuated-Tube Collectors. Evacuated-tube collectors heat water in residential applications that require higher temperatures. In an evacuated-tube collector, sunlight enters through the outer glass tube, strikes the absorber tube, and changes to heat. The heat is transferred to the liquid flowing through the absorber tube. The collector consists of rows of parallel transparent glass tubes, each of which contains an absorber tube (in place of the absorber plate in a flat-plate collector) covered with a selective coating. Evacuated-tube collectors are modular - tubes can be added or removed as hot-water needs change. When evacuated tubes are manufactured, air is evacuated from the space between the two tubes, forming a vacuum. Conductive and convective heat losses are eliminated because there is no air to conduct heat or to circulate and cause convective losses. There can still be some radiant heat loss (heat energy will move through space from a warmer to a cooler surface, even across a vacuum). However, this loss is small and of little consequence compared with the amount of heat transferred to the liquid in the absorber tube. Evacuated-tube collectors are available in a number of designs. Some use a third glass tube inside the absorber tube or other configurations of heat-transfer fins and fluid tubes. One commercially available evacuated-tube collector stores 5 gallons (19 liters) of water in each tube, eliminating the need for a separate solar storage tank. Reflectors placed behind the evacuated tubes can help to focus additional sunlight on the collector. These collectors are more efficient than flat-plate collectors for a couple of reasons. First, they perform well in both direct and diffuse solar radiation. This characteristic, combined with the fact that the vacuum minimizes heat losses to the outdoors, makes these collectors particularly useful in areas with cold, cloudy winters. Second, because of the circular shape of the evacuated tube, sunlight is perpendicular to the absorber for most of the day. For comparison, in a flat-plate collector that is in a fixed position, the sun is only perpendicular to the collector at noon. While evacuated-tube collectors achieve both higher temperatures and higher efficiencies than flat-plate collectors, they are also more expensive.

Low-Temperature Collectors. Low temperature solar collectors are typically unglazed flat-plate collectors, intended to operate at temperatures only 5 to 30 degrees above ambient temperature. Low temperature liquid collectors are used for swimming pool heating. With light glazing and enclosure, they are used as air collectors for agricultural low-temperature applications such as crop drying.

Unglazed collectors with aluminum absorber plates and copper water passages appear to be most cost effective over the typical metal collector lifetime of 20 years or more. All-copper collectors for swimming pool heating also work well, but are generally more expensive for the same performance characteristics. Copper is preferred over any other metal for water passages because of its high conductivity and compatibility with water. Almost all other metals must be separated from direct contact with the water being heated by a heat exchanger, which seriously reduces the collector efficiency.

Unglazed metal collectors for swimming pools almost always have copper in contact with the water flowing through them. Many of them use aluminum for the absorber plate or fins, because of its lower cost relative to copper or other effective materials. Some are all copper, with very thin absorber plate or fins to reduce cost, but at the sacrifice of some efficiency. Water tubes may be soldered, brazed, snapped into grooves or inserted into spring-loaded extrusions.

\subsubsection{Integral collector storage (ICS) used for solar water heating}

The ICS combines thermal collection and storage in a single unit and is designed to meet the international demand for a simple, durable and inexpensive domestic water heating system. An ICS typically serves as a solar preheater to an existing electric or gas water heater, but may be used as the primary water heater in certain climates. ICS units are excellent choices for residential new construction in the U.S. Sunbelt or other mild climates that do not experience hard freeze conditions. Appendix A describes one ICS unit, the CopperHeart, in detail. Figures 20 and 21 show additional solar collector components and supplies that use copper. 
COUECTORS

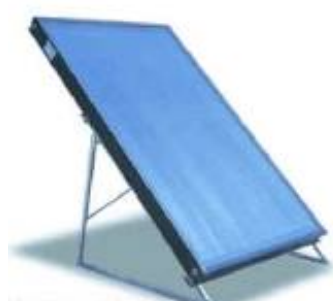

ENVIROSC2,5

Dimension $2006 \times 1236 \times 105 \mathrm{~mm}$

Absorber:BlackChromo costed copper

Low-iton, tempered glass

Stuttgart Uniwersity test report
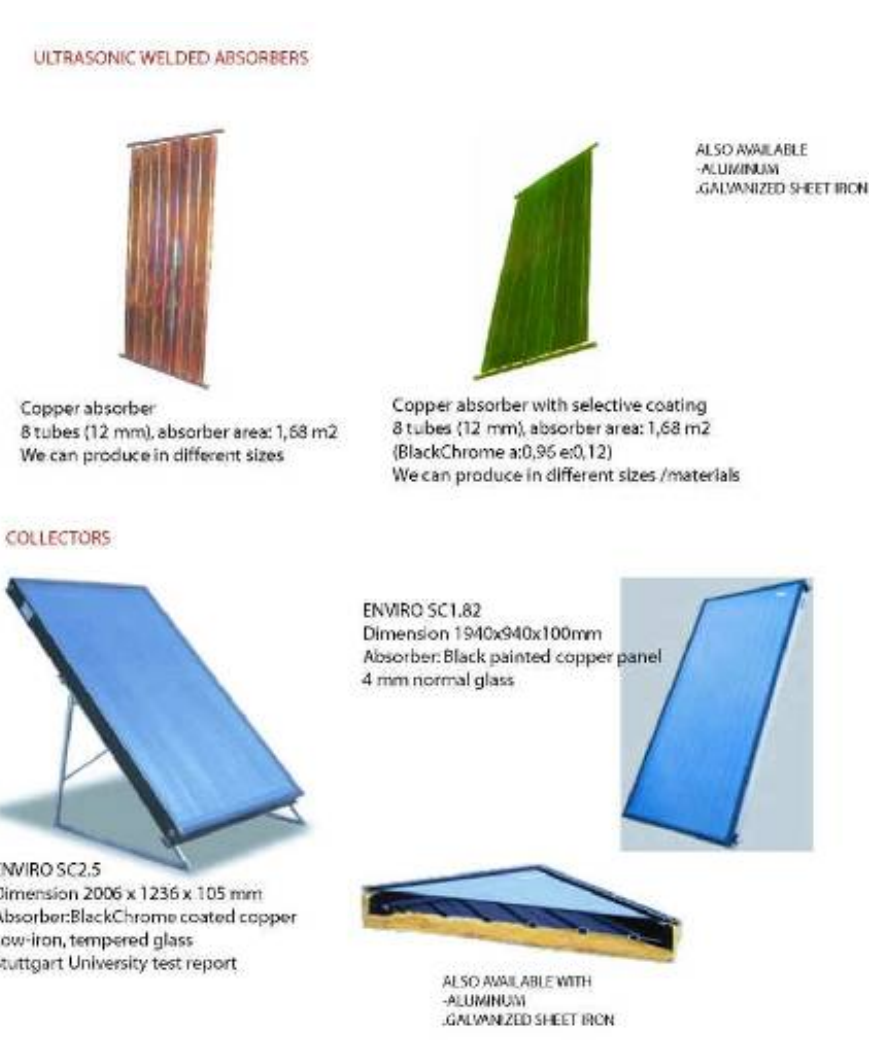

Fig. 20. Solar collector components incorporating

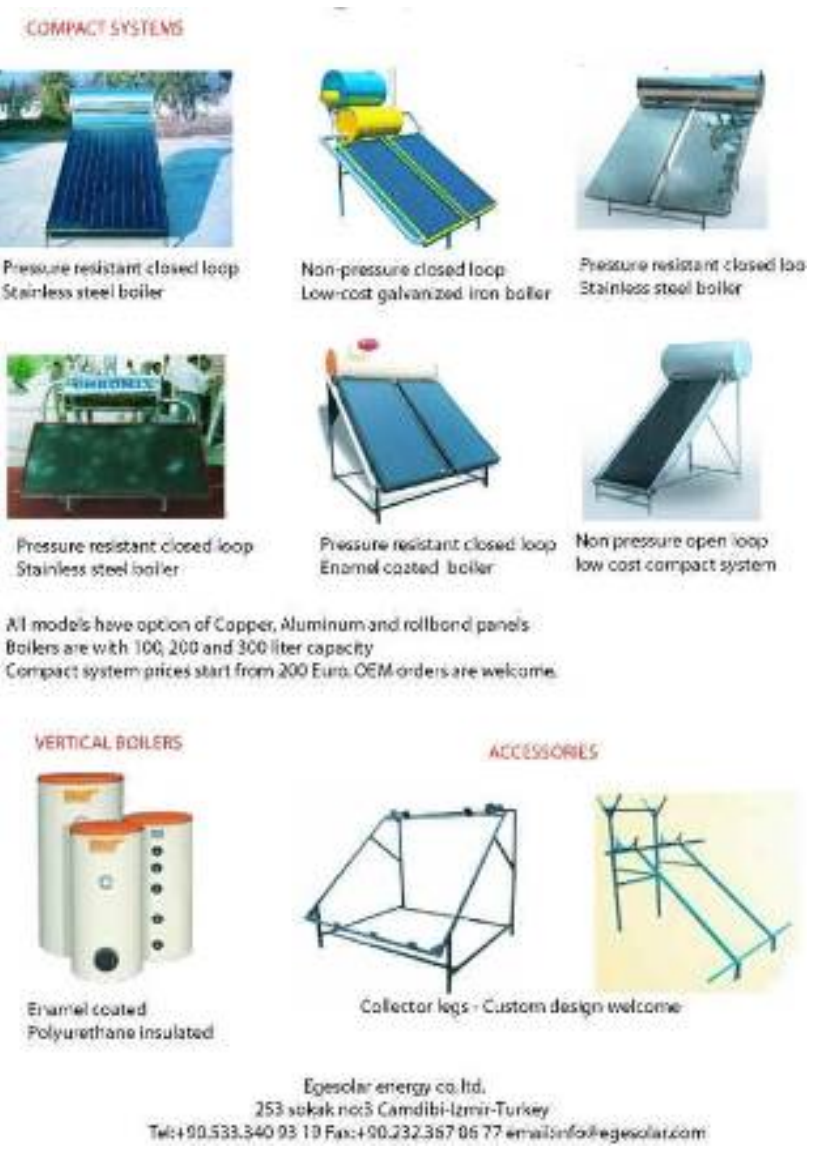

Fig. 21. Additional copper-bearing solar supplies. copper.

\subsubsection{Forecast for Solar Energy}

Solar electric energy demand has grown consistently by $20-25 \%$ per annum over the past 20 years. This has been against a backdrop of rapidly declining costs and prices. This decline has been driven by a) increasing efficiency of solar cells b) manufacturing technology improvements, and c) economies of scale. The PV solar industry now globally generates over US\$3-4bn revenues. This includes the sale of solar modules, its associated equipment and the installation of those systems. In 2001, just less than 350 $\mathrm{mW}$ of solar equipment were sold to add to the solar equipment already generating clean energy.

In 2004, 1,086 Megawatts of PV were installed. This increased to 1460 Megawatts in 2005. Rapid growth of on-grid sales in 2003 led them to be almost double those to off-grid customers, including both industrial (including telecommunications) and habitational applications (mainly in developing countries). In both these off-grid markets, solar power is the 'fuel of choice', and is usually fully justified by its own economics. The majority of on-grid applications are "distributed" — in other words, solar is installed at the point of use (e.g. residential and commercial buildings).

The largest on-grid market by far to date has been Japan, where demand has been stimulated by large government funding programs. This is followed by Germany, where grid-connected applications are also stimulated by major market incentive programs. (See Fig. 22 for solar PV in MW per capita among 18 nations, including the United States, Germany, and Japan.) 
Centralized on-grid applications are those of utilities for inclusion with their portfolio of primary energy sources. The best examples of these installations are in Italy, USA and Spain. However, they are rare and are generally heavily subsidized pilot facilities.

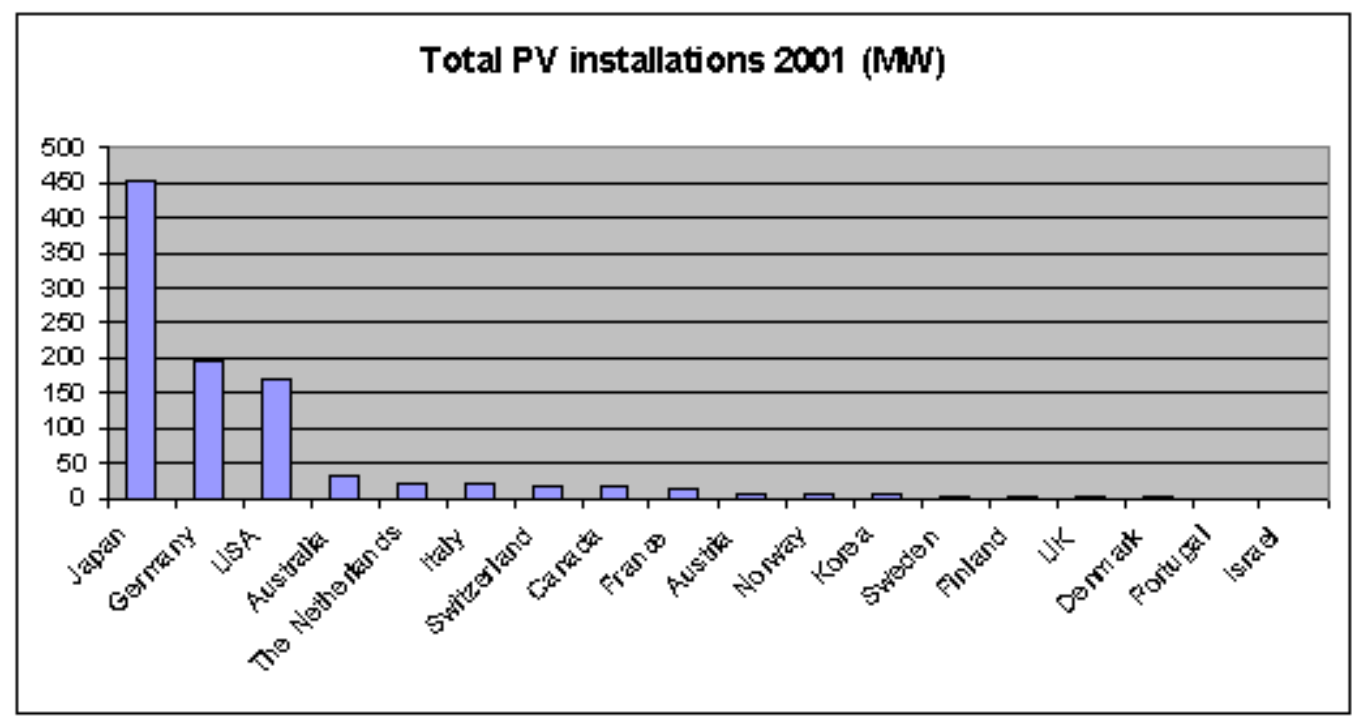

Figure 22. Solar PV by nation (MW per capita).

The European Photovoltaic Industries Association (EPIA) represents the PV industry in Europe. Its latest views on the future, the European PV Road Map may be found at http://www.epia.org/04events/events_ParisConference.htm

There are four major manufacturers of solar modules: Sharp, Kyocera, BP Solar, and Shell Solar (Fig. 23 illustrates market share for the top 10). Together, these companies represent over $50 \%$ of solar electric module production. Sharp and Kyocera have major cell manufacturing facilities in Japan. BP Solar has cell manufacturing facilities in Australia, India, Spain and the U.S. Shell Solar's main cell manufacturing facilities are in the U.S. and Germany. The fastest growing of the major manufacturers in recent years has been Sharp Electronics. The pie chart (Fig. 23) below is measured in megawatts manufactured in 2003. The annual world PV market review, Marketbuzz 2006 addresses this matter and updates the data to 2005 in detail.

The most significant country markets for solar PV are Japan, the USA and Germany. In recent years, the major national market incentive programs have further boosted installations in both Japan and Germany. One result is that Germany has now overtaken the USA. Most of the Japanese and German sales have been to grid-tied applications, mainly for residential roof mounted systems and building integrated PV. US demand has a higher proportion of

\section{Top 10 Solar Cell Manufacturer Production (2003) In Megawatts}

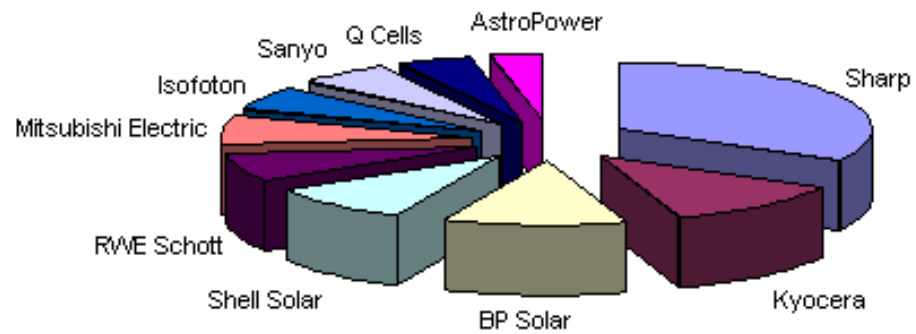

Source: Solarbuzz Inc

Figure 23. Solar cell (PV) manufacturers. 
rural off-grid demand than these other two markets. The following graphs show data for the IEA reporting countries. On a watts-per-capita basis (Fig. 23), Japan overtook Switzerland in 2000 with the most PV installed per person. Germany is poised to overtake Switzerland in 2002. Australia and other European countries demonstrate high levels of use of solar PV systems. The strong position of Switzerland arises mainly from the application by utilities of innovative "solar energy exchanges" to provide a market mechanism matching the aggregated demand of customers willing to pay premium prices for solar electricity with solar power generators on long term supply contracts. These data are brought up to date in our most recent Annual World PV Market report, Marketbuzz 2006.

\subsubsection{Driving Forces of Growth in Country Markets}

Among the industrialized countries, the Japanese and German governments have led the way in legislating for the use of high subsidies to stimulate development of their domestic solar markets. This has caused evolution of the industry structure in each country and led to strong distributor and dealer networks with well-trained installers and good customer support capabilities. Underlying government policy has been the desire both to reduce CO2 emissions via solar deployment and to develop a strong national solar industry creating high technology jobs. Japan in particular now has a much stronger PV manufacturing base, developed in response to domestic demand. In the USA, utilities have played a stronger role in market development. Table 1 shows the annual budgets for R\&D, simulation, and market demonstration for solar technologies for Japan, Germany, and the United States.

Overall, the drivers of regional solar energy demand in applications where the solar energy is connected to the electricity grid are:

- regional programs led by national or state governments and the extent of subsidies within these

- the enthusiasm of customers for green energy especially solar

- local electricity tariffs (high electricity rates encourage alternative sources of energy)

- $\quad$ solar (sunlight) conditions (solar electricity prices fall as sunlight levels increase)

- marketing strategies by solar companies

- the extent of the "delivery infrastructure” (the number of local suppliers and qualified installers)

Table 1. Breakdown of annual budgets 2001

Source: IEA PVPS

\begin{tabular}{|l|r|c|c|}
\hline & Japan & USA & Germany \\
\hline Research and development & 51.0 & 35.0 & 26.7 \\
\hline Demonstration & 16.5 & 0.0 & 5.5 \\
\hline Market stimulation & 188.4 & 84.6 & 29.6 \\
\hline
\end{tabular}

There is evidence that corporations may install solar for "brand value" and some premium may be available from residential users to access a clean energy source. However, during the period that solar costs more than fossil fuel, some fiscal stimulation is required to secure on grid sales. The quid pro quo from the solar industry is a continuation on the path to a self sustaining industry. Most forecasts suggest that such an outcome will be realized within the next decade. 
In developing countries, markets have benefited from the steady decline in solar PV prices but they have also been stimulated by continued multi-lateral and bi-lateral development aid. This has meant that solar has been employed increasingly as an enabling technology behind developmental programs for education, water supply and healthcare. There is an increasing focus on micro-finance to improve the affordability of solar PV systems that may be economical over their life but have high initial costs. Such credit schemes have been effective at a small scale, but a culture of credit does not exist yet in many developing countries. The notable country that has a strong commercial (un-subsidized) market is Kenya, where customers opt for low power (10-20W) entry level modules.

The gap between solar and fossil fuel sourced electricity, means that short term on grid market demand is driven by the extent of government or utility funding programs.

\subsubsection{World solar market growth}

According to a recent Reuters article, the world solar market jumped 70 percent in 2004. Figure 25 shows solar PV growth from 1999-2003. Last year, world solar cell production reached $1,256 \mathrm{~mW}$ or about enough to power more than 1.2 million average American

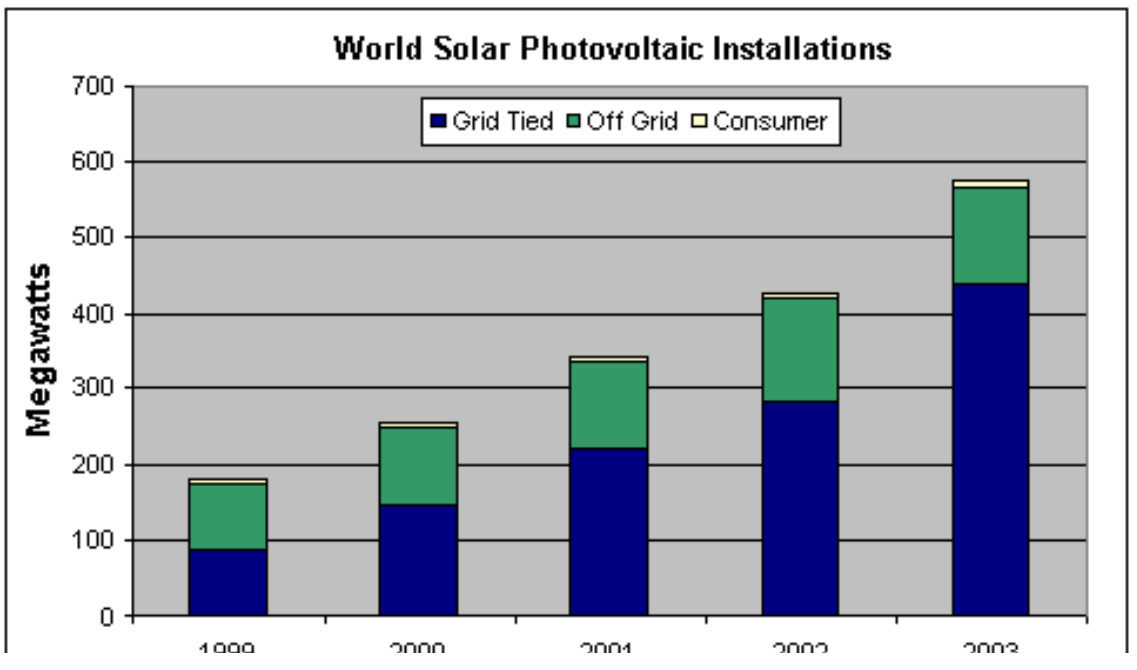

Fig. 24. World solar PV installations. homes during daytime.

Governments that have supported budgets have done so for the environmental and economic benefits. This funding can bring forward the point the solar becomes economic in on-grid markets, since a key success factor for the industry is the lower costs that will come through high volume manufacturing.

Researchers are studying routes for developing processes suitable for manufacturing to facilitate the deployment of copper indium diselenide technology. This work focuses on processes that are inexpensive and high performance. Four primary processes are being studied, and the most promising will be chosen for further development. This research concentrates on the following four areas:

- Developing deposition methods suitable

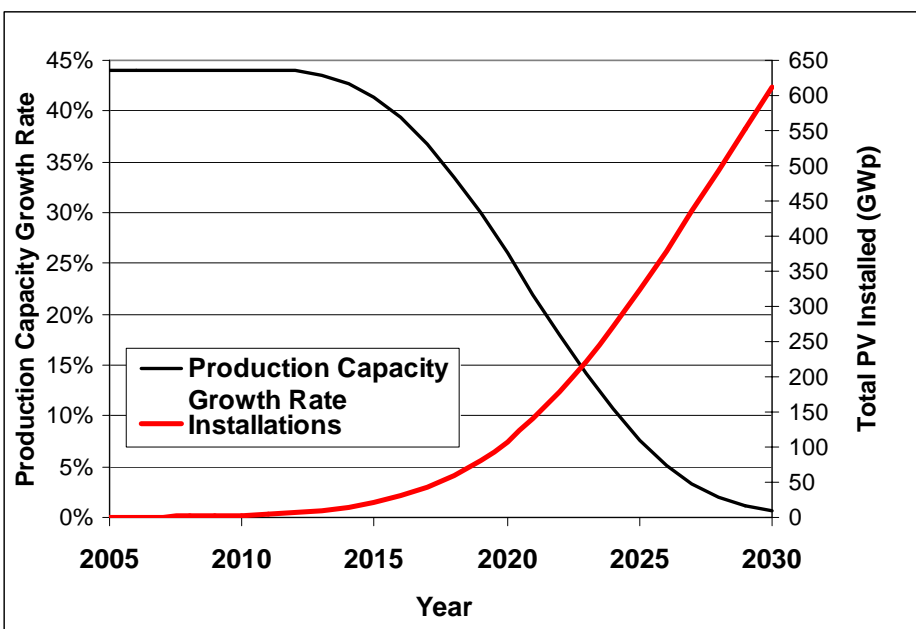

Fig. 25. Expected solar PV deployment. for commercializing the CIS technology.

- Developing methods for forming of an in situ junction into the absorber fabrication process that does not use cadmium sulfide. 
- Studying the effect of the glass substrate and molybdenum contact on CIS-based solar cells as well as alternatives to glass/Mo designs.

- Developing a more reliable molybdenum deposition system and a direct-current reactive zinc oxide process amenable to scale-up and fast deposition rates. Such a system is essential for advancing CIS technology from the fundamental to pre-commercialization stage.

\section{Outlook for Solar in the U.S.} Figure 28 shows the Energy Outlook projection for solar thermal, solar PV, and the sum of two. This figure (data taken from Table 17 of the reference case tables for Energy Outlook 2006 of the Energy Information Administration website, http://www.eia.doe.gov/oiaf/aeo/excel/aeo tab 17.xls) does indicate an overall increase of $2.8 \%$ per year for solar hot water heating. At present, the copperintensive solar thermal industry has greater electricity capacity but will eventually be overtaken by PVs. It may be observed that the solar PV industry has a more optimistic view and assumes an average of a $30 \%$ increase per year. Recent years have achieved this. Nevertheless, even if this growth does happen, it will not become significant in comparison to other renewable energies until the year 2015 .

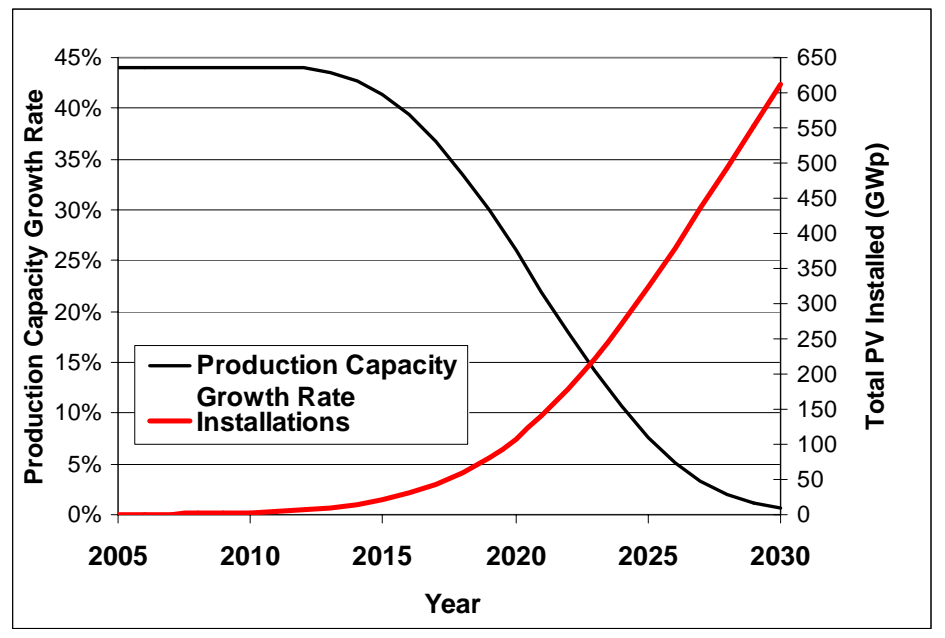

Fig. 26. Expected solar PV deployment.

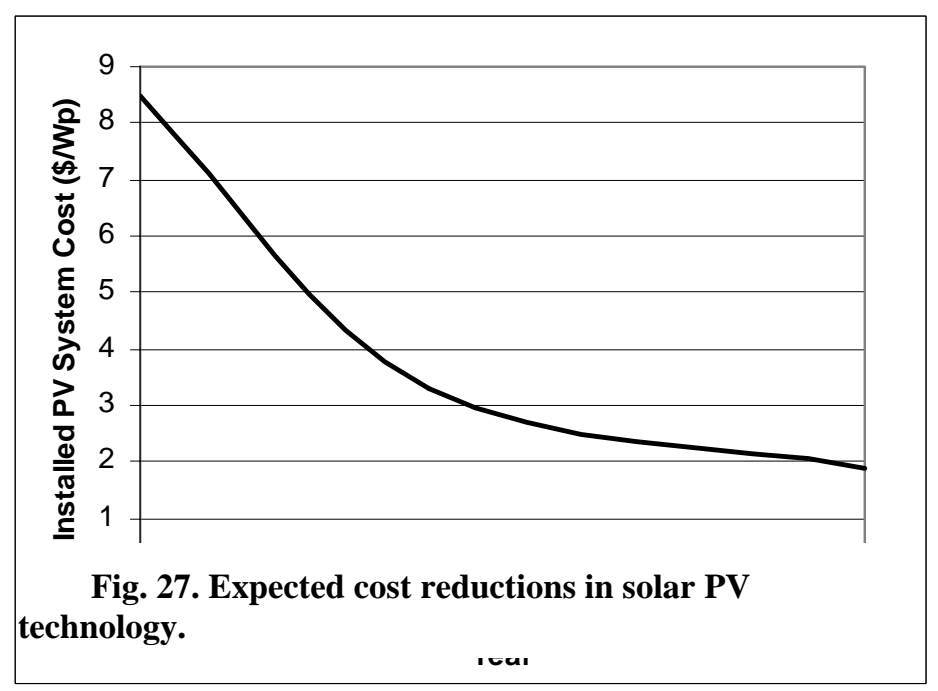

It is important to note that the solar thermal power generation plotted in Fig. 28 is due to about a dozen concentrated solar power (CSP) plants. Sales of CSP thermal power account for less than one per cent of the total solar thermal market. ${ }^{28}$ Overall, solar energy electricity generation will increase by a factor of four over the 28-year period. However, it will remain a small percentage within the renewable energy subset. Even with an additional cost reduction of $10 \%$ on a site-specific basis, there is no significant change.

There are a large number of niche applications for solar energy and it is difficult to combine the many disparate situations and products for a solid quantitative analysis. Solar energy is divided into two major categories, solar PV and solar thermal. One aspect of solar thermal is solar hot water heating. It presently makes up about $1 \%$ of the water heating business and dozens of companies serve that market. Some of the products in this area utilize prodigious amounts of copper in comparison to other energy producing technologies. Table 2, based on information from the Solar Rating and Certification website, conveys this. Example A was determined by noting that some flat collectors use as much as $35 \mathrm{lb}$ for an 
area of approximately $6 \mathrm{~m}^{2}$. According to the Solar Rating and Certification Corporation, a typical $6 \mathrm{~m} 2$ solar collector will deliver $4 \mathrm{~kW}$ of equivalent thermal power. This assumes full sun and no temperature difference between the water and ambient temperature. Based on this hypothetical situation, this corresponds to $4 \frac{1}{2}$ tons of copper per MW.

Example B is based on a product currently under development that utilizes an estimated $3 \mathrm{lb}$ of copper in a unit specified as 125 Watts. This corresponds to 12 tons of copper for generating $1 \mathrm{MW}$. Projections in terms of megawatts are not presented in the Energy Outlook report. A value of 4.5 and 12 tons of copper per MW is determined. These are only two examples; some products use less copper. Currently, there are many different types of solar thermal units on the market. This renders a determination of average tons of copper per MW.

Table 2. Estimates of Solar Thermal Copper Usage Rates

\begin{tabular}{|l|l|l|l|l|}
\hline & Area $\mathbf{m}^{2}$ & Copper & $\begin{array}{c}\text { At sun's peak: } \\
\text { equiv. elec. power }\end{array}$ & $\begin{array}{c}\text { Tons } \\
\text { copper/MW }\end{array}$ \\
\hline Example A & $6 \mathrm{~m}^{2}$ & $35 \mathrm{lb}$ & $4 \mathrm{~kW}$ & $4 \frac{1 / 2}{2}$ \\
\hline Example B & unknown & $3 \mathrm{lb}$ & $125 \mathrm{~W}$ & 12 \\
\hline
\end{tabular}

Source: Solar Rating and Certification Corporation website: http://www.solarrating.org/solarfacts/solarfacts.htm

Solar PV technology is predicted to grow rapidly. However, it is starting at such a low level that it will not be significant for at least ten years. The amounts of copper can vary depending on many details and even which formulations for the PV cells will be fielded.

Solar PV technology is predicted to grow rapidly. However, it is starting at such a low level that it will not be significant for at least ten years. The amounts of copper can vary depending on many details and even which formulations for the PV cells will be fielded.

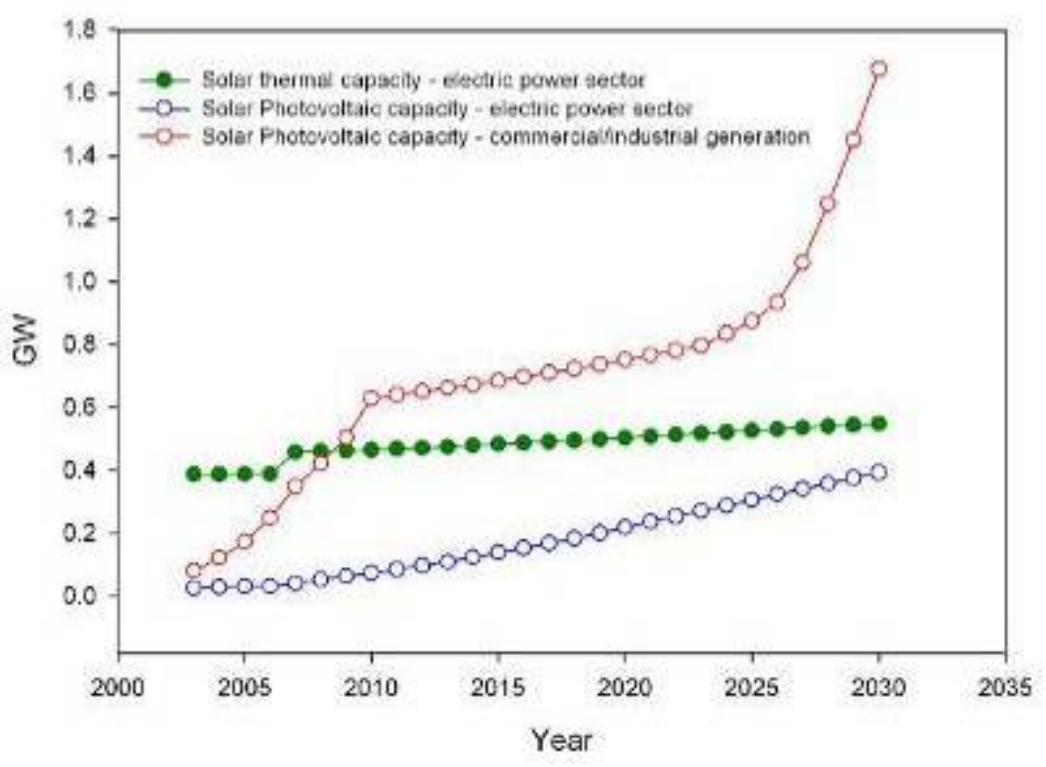

Fig. 28. Energy outlook for solar technology. 


\subsection{HYDROPOWER}

Hydropower refers to the production of power from moving or falling water. The most common hydropower energy sources are water stored in a reservoir behind a dam and water flowing through a river channel. Hydropower constitutes the largest portion of renewable energy-based electrical power generation in the U.S. It provides about $10 \%$ of our electrical power requirements.

\subsubsection{Hydropower Technologies ${ }^{29}$}

The most common use of hydropower energy is to generate electricity. Water released from an impoundment facility (a reservoir formed by a dam) flows through a turbine, forcing the turbine to spin, and the spinning turbine drives a generator that produces electricity. An alternate method of using hydropower to generate electricity is to divert a portion of a river into an adjoining channel where the water current drives a turbine and generator.

In some instances a hydropower facility is designed to use its turbines to pump water into the reservoir. This hydropower facility — called a pumped storage plant—makes use of excess electrical power, typically that generated by a nuclear power plant during periods of low demand. The pumped storage plant then generates power during periods of peak demand.

\subsubsection{Uses of copper in hydropower technologies}

The primary use of copper in hydropower technologies is in the coil windings in the stator and rotor portions of the generator and in the conductors in high-voltage power cables.

\subsubsection{Forecast for Hydropower}

As seen in Fig. 29, hydropower is expected to remain essentially the same.

"While wind and solar power are the fastest growing renewable energy sources, hydropower is the most established renewable energy technology, representing more than 75 percent of the electricity generated by renewable sources in the United States and supplying about 10 percent of the nation's total electricity capacity. ${ }^{30}$

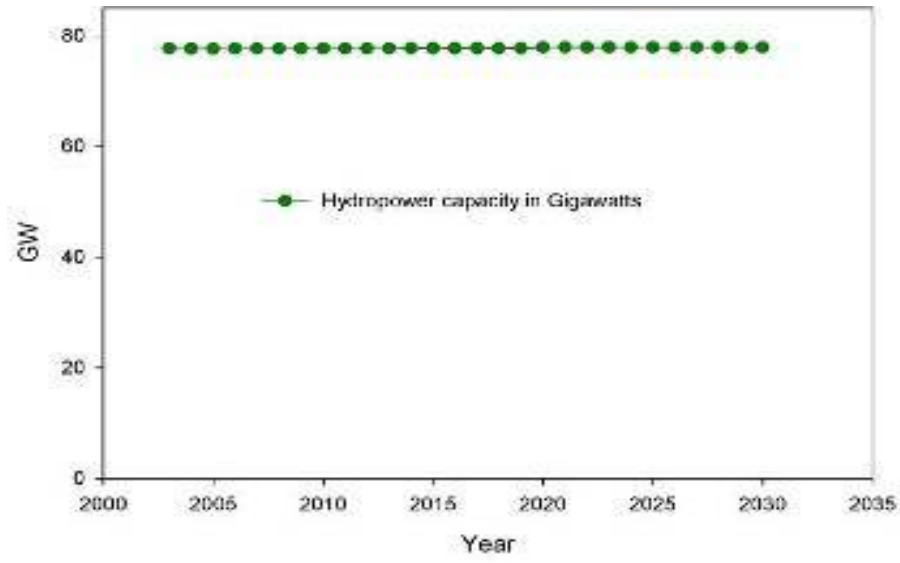

Fig. 29. Electricity from renewable resources: hydropower.
The main trend in the hydro industry today is refurbishing and upgrading existing hydro plants as a cost-efficient, economically sound use of a wellestablished renewable energy technology, according to Kate Brass, Marketing \& Communications manager for GE Energy.

For more than a decade, GE has been working with customers to develop new hydro turbine technologies that resolve environmental issues, such as the recent development of a turbine blade designed to reduce fish injury and mortality. GE also has successfully

\footnotetext{
${ }^{29}$ The discussion at http://www.eere.doe.gov/RE/hydropower.html is a good source of additional information.

${ }^{30}$ Blankinship, S. 2005. Power Engineering International. January.
} 
developed and implemented designs to minimize or eliminate the use of oil in the hubs of Kaplan hydro turbines, preventing possible oil seepage into waterways.

DOE estimates that as much as 21,000 MW of hydropower capacity sits unused at existing hydropower facilities and non-hydropower dams. Of that amount, the National Hydropower Association (NHA) estimates that 4,300 MW of additional hydropower could be gained from upgrading existing hydropower facilities through increasing project efficiencies or adding capacity using new technology, such as the Advanced Hydropower Turbine (AHT) being developed by DOE and the hydro industry to improve fish passage and increase efficiency and power output. Such an expansion of existing sites would avoid 42 million metric tons of $\mathrm{CO}_{2}$, along with substantial amounts of $\mathrm{NO}_{x}, \mathrm{SO}_{2}$, mercury and fine particulate matter.

The first AHT was installed this past fall on the Columbia River's Wanapum Dam, and testing, which begins this spring, could pave the way for other projects with fish migration issues. "The AHT could practically eliminate the impact of dams from a fish passage standpoint," says Mark Stover, director of government affairs and media relations for NHA. "This is potentially a huge turning point for the hydropower industry."

The quoted text above, taken from an article from the trade journal Power Engineering International, reveals the extent and importance of hydropower. Hydropower is expected to remain level in terms of output. This is reflected by Energy Outlook 2006 data that is plotted in Figure 29. However, the journal article does indicate that the hydro industry is refurbishing and upgrading present hydro facilities. This reference also refers to efforts by a turbine manufacturer to develop new turbine technology for reducing harm to fish and also to decreasing or eliminating the use of oil in turbine equipment. The article mentions but does not reference a DOE suggestion that as much as 21 GW hydropower capacity is unused.

Hydropower uses turbine generator technology and significant amounts of copper. However, this technology will remain stable in terms of power production for the near future according to the EIA. Some equipment upgrades and refurbishment are to be expected.

\subsection{OCEAN}

Ocean energy technologies are based on the extraction of thermal energy provided by solar heating of the water and on the use of the mechanical energy of tides and waves. Oceans are the Earth's largest solar collectors - they cover more than two-thirds of its surface. Each day the solar energy absorbed by the oceans results in water heating equivalent to the thermal energy stored in 250 billion barrels of oil.

Tides and waves are the two sources of mechanical energy from the ocean. The gravitational attraction of the moon produces tides while surface winds produce waves. The power of waves breaking on the earth's coastlines has been estimated at 2 to 3 million $\mathrm{mW}$. In some locations, the wave power averages $65 \mathrm{~mW}$ per mile of coastline.

\subsubsection{Ocean Energy Technologies ${ }^{31}$}

The solar energy absorbed at the surface of the oceans produces a rise in water temperature in the surface layer. The energy stored in this thermal reservoir can be used to generate electricity. There are three Ocean Thermal Energy Conversion (OTEC) technologies that utilize this thermal reservoir: closedcycle, open-cycle, and hybrid systems. A closed-cycle system uses the warmed surface water to vaporize a low-boiling point fluid such as ammonia. The vaporized fluid then drives a turbine and generator. An open-cycle system vaporizes the warmed seawater by lowering the pressure in the boiler, producing steam

\footnotetext{
${ }^{31}$ The discussion at http://www.eere.doe.gov/RE/ocean.html is a good source of additional information.
} 
that drives the turbine and generator. A hybrid electricity-generating system combines aspects of the closed-cycle and open-cycle systems. An added benefit of some OTEC technologies is that they are capable of producing desalinated water while generating electrical power.

Using tidal energy usually requires the construction of a dam across the opening to a tidal basin. When the tide is rising, the sluice gate in the tidal dam is opened to allow water to flow into the basin. The gate is then closed when the tide begins to fall. When the difference in water levels between the basin and open sea is sufficiently great, hydropower technology is used to provide the energy to drive turbines and generators.

Some progress is being made on technologies that extract energy from tidal flows without the use of a dam. Power generation turbines are being tested in the East River near New York City. ${ }^{32}$ The turbines are submerged safely below the river's surface, and they are powered the rapid river currents that are caused by rising and falling tides.

There are three methods for using wave energy to generate electricity: channeling waves into reservoirs, using float systems to impel hydraulic pumps, and using an oscillating water column to compress air for work. Each method provides energy to drive turbines and generators. Figure 30 shows a new concept by Oregon State University that depends on the rising and falling of water level.

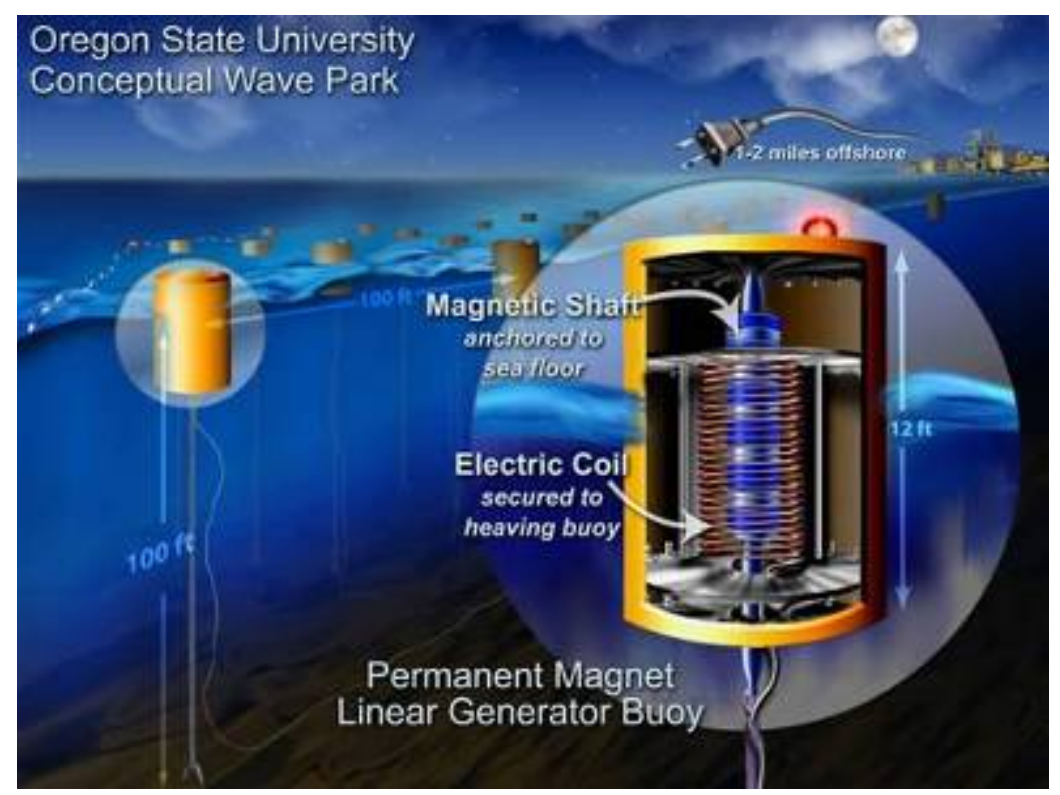

Fig. 30. Ocean energy vision.

\subsubsection{Offshore Platforms}

Many offshore oil fields no longer have enough gas to run the offshore platform generators to keep the platforms operating and burn diesel is too costly. So oil platforms are getting abandoned leaving 80 to $90 \%$ of the oil in the ground. When a platform is no longer in operation, the United States requires it be totally removed to $15 \mathrm{ft}$ below the mud line eliminating almost all economic methods of recovery this oil in the future.

\footnotetext{
32 “In Search of New Power Source, City Looks Underwater,” The New York Times, July 10, 2004, p. B-3.
} 
DOE is interested in the concept of powering offshore platforms with alternative energy. This electric power would be used to run pumps down the hole in the oil wells that would pump out the rest of the oil out at high rates. These same pumps could greatly increase all the flow rates of all the offshore oil wells on platforms not even planned to be abandoned. Platform owners would profit; and these platforms would generate revenue for the U.S. government, which would help balance the trade deficit.

\subsubsection{Copper Findings for Ocean Energy}

This section highlights two companies that use copper in ocean-generated energy.

Offshore Islands Limited. This company has several patents that enable ocean currents, waves, and winds to be collected and converted into significant electric power for both offshore and onshore use. These patents provide the lowest cost option for major renewable alternative energy power farms. The patents have been developed by one of the most experienced high tech U.S.-based offshore structural engineers. This engineer was instrumental in the design of the first tension leg platform (TLP), first Spar, first mini TLPs, and now the latest generation of ultra-deep-water/ultra-low-cost floating offshore platform, the tension leg counter-weight platform (TLCWP). This engineer has been designing platforms for the oil industry for more than 30 years. ${ }^{33}$ It uses copper in the generators, the electrical bearings, and the power cables that transfer the electrical power generators to the end users.

Offshore Islands' plans to hub all its generators on central offshore platforms with above-water control systems, switchgears, and transformers. To further reduce cable lengths and cost, the company plans to also raise the voltage to the most efficient transmission levels to minimize the size of the power cables to the beach and the length of power cables between each generator, between each generator support frame, and to the beach. For example, cable bridges will be installed between each generator support frame, rather than taking the cables to the seabed and back up again; also, cables could be hubbed into subsea junction boxes to minimize the number of individual cables and design/size all cables for the individual branches of the system. Fiber-optic cables and/or underwater acoustic devices not requiring copper will probably be used for subsea instrumentation and monitoring. ${ }^{34}$

Gulfstream Technologies. ${ }^{35}$ Gulfstream Technologies is a sub-sea power generating company that uses oceanic currents to create massive amounts of electricity as well as large quantities of public drinking water. Gulfstream Technologies proprietary patented technology can be deployed in numerous world-wide locations.

\subsubsection{Forecast for Ocean Energy Technologies}

According to the AEO pp.47-49 there are some wave energy technologies under development and there are a handful of tidal power stations around the world operating commercially. The scarcity of data concerning these is so low that the Energy Information Administration could not make a reasonable

\footnotetext{
${ }^{33}$ Offshore Islands Limited offers ocean energy systems, wind power plants, hydro energy system components (large), ocean current power generation stations, ocean wave power generation stations, ocean wind power generation stations, and ocean fresh water supply stations. The company also provides offshore structural engineering and alternative ocean power generation. (http://www.offshoreislandslimited.com)

${ }^{34}$ From email communications with Don Gehring of Offshore Islands Limited.

${ }^{35}$ Gulfstream Technologies manufactures ocean energy systems and water filtering and purification systems. http://gulfstreamtechnologies.com. View online technology presentation by invitation only (pending patent). Contact Phillip P. Janca, pjanca@gulfstreamtechnologies.com, (940) 564-5682.
} 
market assessment for the 2006 publication. Ocean thermal technologies have restrictive technical and topographic requirements that limit them to certain near tropical locales. Virtually the entire United States continent does not fulfill these requirements. Nonetheless, there is interest in ocean tidal technologies as the existence of the two private companies above attests.

Like hydropower ocean energy using the movement of water has potential for significant copper usage. There are a variety of technologies that come under this heading. Not enough activity is occurring at present for reliable projections to be made.

\subsection{HYDROGEN}

Hydrogen is an energy carrier and is not itself a source of energy. In its pure elemental form hydrogen can be combusted with oxygen to produce thermal energy or processed with oxygen in a fuel cell to yield electrical energy.

Hydrogen can be produced by separating it from hydrocarbons, carbohydrates, and hydrides or hydrates through processes known as "reforming." At present, methane (natural gas) is the hydrocarbon compound used most often in reforming saleable hydrogen. Electric current and high temperatures can be used to separate water into hydrogen and oxygen. Certain species of algae and bacteria can produce hydrogen or hydrogen compounds metabolically under particular conditions. In the some cases, the algae can use sunlight and photosynthesis as its energy source. The technologies for bioproduction of hydrogen are in the early stages of development.

The concept of a "Hydrogen Economy," where hydrogen-based energy technologies comprise the basic energy infrastructure and replace a large portion of the fossil fuel-based energy infrastructure, is a promising one, although many energy experts believe that the realization of this idea-if it is realized at all-is decades in the future.

\subsubsection{Hydrogen Technologies ${ }^{36}$}

Most of the current interest in hydrogen as a renewable energy source is related to its potential use in fuel cells. The technologies for fuel cell-powered electric vehicles are an especially active area of research and development in the U.S.

There are many diverse technological initiatives for producing hydrogen. The U.S. Department of Energy funds research and development in hydrogen production with the goal of doing so in economically and in environmentally friendly ways. These production initiatives are largely in hydrogen reforming and in renewable energy technologies such as biomass, wind, solar, geothermal, and hydroelectric power.

Once hydrogen is being produced, it is necessary to have a delivery infrastructure to deliver it from where it is produced to its point of end-use, such as a dispenser at a refueling station or stationary power site. Infrastructure includes the pipelines, trucks, storage facilities, compressors, and dispensers involved in the process of delivering fuel.

DOE is working closely with the national laboratories, universities, and industry partners to overcome critical technical challenges to fuel cell commercialization. Cost and durability are the major challenges to fuel cell commercialization. Other challenges are size, weight, and thermal and water management. In stationary power applications, where cogeneration of heat and power is desired, use of PEM fuel cells would benefit from raising operating temperatures to increase performance.

\footnotetext{
${ }^{36}$ The discussion at http://www.eere.doe.gov/RE/hydrogen.html is a good source of additional information.
} 


\subsubsection{Uses of copper in hydrogen energy technologies}

Copper is contributing to many aspects of hydrogen fuel cell advancement and fuel cell-powered vehicle development. In the area of hydrogen storage technology, copper has been shown to be useful for fabricating nanopores in materials that provide hydrogen absorption. Dense metallic membranes, such as alloys of palladium and copper, are useful for hydrogen separation and purification, as these membranes have very good tolerances to sulfur poisoning. Semiconductor materials such as copper-indium-diselenide and copper seleno-antimonate compounds have electronic and photonic properties that are enabling solar conversion (water splitting) efficiencies that are nearing $20 \%$.

There are a number of perceived advantages for moving to a hydrogen economy. Hydrogen fuel cells could be a significant application for copper. However, it does not appear that adequate advances in the technology will occur in the next fifteen years for this to be of significance.

\subsubsection{Forecast for Hydrogen Technologies}

"Many technologies for producing hydrogen are commercially available today, but they are expensive. Without significant technological progress, it seems unlikely that substantial incremental amounts of hydrogen will be produced before 2030.” (AEO, p. 48) 


\section{RENEWABLE PORTFOLIO STANDARDS}

\subsection{GOVERNMENT INCENTIVES}

A variety of government incentives continue to promote the use of renewable energy in the United States. A greater understanding of these incentives is instrumental for estimating what type of support renewable energy technologies will receive from the government in the future, as well as what types of opportunities currently exist for consumers and companies to take advantage of.

Largely as a result of the "energy crisis" of the 1970s, federal and state governments have instituted a variety of policies for encouraging renewable energy technologies. Presidents Nixon and Ford hoped that concerted efforts would yield “energy independence," which generally meant the end of reliance on unstable foreign supplies of energy (largely oil). Going beyond rhetoric and some modest legislation, President Carter proposed an aggressive energy policy that included incentives for increased domestic production of energy (including the use of renewables) and energy efficiency. Seriously watered down by Congress, his policy nevertheless provided several valuable incentives for renewables. President Reagan allowed provisions of many of the energy laws to expire, along with them incentives for renewable energy and energy efficiency. Market forces, which he encouraged, and the collapse of OPEC discipline, led to more than a decade of relatively low energy prices, which diminished interest in alternative energy technologies. In contrast, the recent rise in energy prices may serve as an incentive to entrepreneurs and homeowners to pursue renewable energy and energy efficiency.

Policies supportive of renewable energy consisted of legislative mandates—one in particular-that enabled novel technologies to be used within the formerly regulated electric utility industry. More commonly, legislation offers financial incentives (such as tax credits) to encourage development and installation of renewable technologies.

\subsection{LEGISLATIVE MANDATE}

The major legislative mandate spurring work on renewable energy technologies consisted of the Public Utility Regulatory Policies Act (PURPA) of 1978 (P.L. 95-617). Passed as one of five diluted measures of President Carter's national energy plan, the law primarily encouraged electric utility companies to reform rate structures so customers would reduce wasteful consumption of power. However, one part of the law also had wide-ranging effects on companies and individuals that sought to use nontraditional sources of energy to produce electricity: it required power companies to purchase electricity produced by non-utilities if generated from highly efficient cogeneration plants and from renewable energy facilities. Previously, utilities could decline to purchase such power created by these small-scale, decentralized producers, or they could offer low prices. PURPA, on the other hand, mandated that utilities purchase this power at rates that equaled their own cost of producing electricity.

In some states, regulators set these rates at high levels as a way to encourage production from renewable and cogenerating plants. By doing so, they motivated large research and development efforts on the technology, which contributed to huge declines in the cost of producing power. Largely because of the stimulation of PURPA, for example, entrepreneurs developed small wind turbines (between 0.05 to $0.5 \mathrm{MW}$ ) for use in clusters, with the amassed electricity sold to utilities. Costs dropped throughout the 1980s and into the 1990s such that wind turbines now produce larger amounts of power (up to 3 MW per turbine) at costs comparable to fossil fuel (including natural gas) in some parts of the country, and cheaper than other non-hydro renewable resource. Solar cell technologies also saw major improvements under the impetus of PURPA: costs per kWh dropped from about 90 cents in 1980 to about 20 cents in 1995.

PURPA's effect has been limited by subsequent legislation. While the law remains in force (despite 
efforts to repeal it by those who believe it encourages expensive and unneeded power), the Energy Policy Act of 1992 has created a new class of independent generators (known as exempt wholesale generators) that sell power into an open wholesale (and sometimes retail) market. Moreover, some states have seriously weakened the incentives offered to generators that took advantage of PURPA's provisions. The Energy Policy Act of 2005 further amended PURPA and limits the ability of some non-utility generators to sell power to the grid.

\subsection{FINANCIAL INCENTIVES}

Many pieces of legislation provided direct and indirect support of renewable resources over the years. For example:

Energy Tax Act of 1978 (P.L.95-618). The law offered income tax credits (30 percent of the first $\$ 2,000$ and 20 percent of the next $\$ 8,000$ ) to residential users of solar and wind-powered technologies. Businesses earned a 10 percent tax credit in addition to a 10 percent investment tax credit on solar, wind, geothermal, and ocean thermal technologies. Many of the law's credits were allowed to expire between 1982 and 1985, during the Reagan administration.

Crude Oil Windfall Profits Tax Act of 1980 (P.L.96-223). Augmenting the terms of the Energy Tax Act of 1978, this legislation boosted the residential tax credit for solar, wind, and geothermal energy technologies to 40 percent for the initial $\$ 10,000$ in costs. Businesses also saw their tax credit for renewable energy technologies grow from 10 to 15 percent, while extending the credits until the end of 1985. Other terms allowed for tax-exempt interest to be paid on industrial development bonds for wasteto-energy, hydroelectric, and renewable energy facilities.

Economic Recovery Tax Act of 1981 (P.L.97-34). An early piece of legislation during the Reagan administration, this law permitted accelerated depreciation of capital for renewable energy equipment. It also offered a 25 percent tax credit for spending on research and development.

Tax Equity and Fiscal Responsibility Act of 1982 (P.L.97-248). This law ended further acceleration in the depreciation formula created by the 1981 Economic Recovery Tax Act.

Tax Reform Act of 1986 (P.L.99-514). Though it repealed the 10 percent investment tax credit that benefited investors of renewable (and nonrenewable) energy technologies as well as the tax-free status of some industrial development bonds and other credits, it extended the business tax credits for some renewable technologies. For the first time, renewable energy technologies owned by public utilities could be depreciated on an accelerated basis. However, the business energy tax credit for wind-powered systems was not extended; it expired at the end of 1985.

Energy Policy Act of 1992 (P.L.102-486). A major piece of legislation that sought to employ market forces to spur energy production and energy efficiency, the Energy Policy Act contained several provisions for renewable energy technologies. It gave a 10 percent business tax credit for purchases of solar and geothermal equipment. Perhaps most importantly, it offered a 10-year production tax credit of 1.5 cents per kWh for wind projects and biomass plants installed before mid-1999. The law also provided some tax credits for business investments in solar and geothermal facilities. The production tax credits were extended by Congress annually until the end of 2003. Congress did not re-extend the credit until October 2004, with another expiration set for the end of 2005. (See Energy Policy Act of 2005, below, for more information on the production tax credits.)

Tax Relief Extension Act of 1999 (P.L. 106-170). As some of the terms of the Energy Policy Act of 1992 were about to expire, Congress passed this legislation, which extended and modified the production tax credit for wind turbine projects and some biomass facilities. Installations of these facilities needed to be completed before the end of 2001.

Energy Policy Act of 2005 (P.L. 109-58). Passed by Congress after years of debate, the law provides several incentives for renewable energy, partly in return for extensive incentives for fossil and 
nuclear fuel technologies. Wind power entrepreneurs celebrate the fact that the law extends the production tax credit (at a rate of 1.9 cents per kWh) until the end of 2007. Previously, Congress allowed the tax credit to expire before renewing it. By providing continuity, the boom and bust cycle of investment in wind turbine technology will likely diminish. The law also requires purchase of power produced by ocean (current, tidal, or wave) technologies. Moreover, the new act provides federal tax credits for solar energy homes. According to the Department of Energy, homeowners and businesses will receive a credit of up to thirty percent of the cost of installing a solar power, solar hot water, or solar thermal system. The solar energy tax credit is capped at $\$ 2,000$ for each type of system and applies to systems installed during 2006 and 2007. Finally, the energy bill reauthorizes the Energy Savings Performance Contract Program, which allows private contractors to help federal agencies improve the energy efficiency of their facilities by installing more efficient technologies such as renewable energy systems.

\subsection{A CLOSER LOOK AT RECENT TAX CREDITS AND LOAN GUARANTEES FOR RENEWABLE ENERGY}

\subsubsection{Major Production Tax Credit Provisions in the Energy Policy Act of 2005 (EPACT)}

The federal government has a Renewable Energy Production Incentive that provides financial incentives for electricity sold by new qualifying renewable energy. The Energy Policy Act of 2005 (EPACT) offers consumers and businesses federal tax credits beginning January, 2006. Eligible electric production facilities are those owned by state and local government entities (such as municipal utilities) and not-for-profit electric cooperatives. Qualifying facilities are eligible for annual incentive payments of 1.5 cents per $\mathrm{kWh}$ for the first 10 -year period of their operation. This incentive is not considered bankable since it must be appropriated each year by Congress. A tax credit is generally more valuable than an equivalent tax deduction because a tax credit reduces tax dollar-for-dollar, while a deduction only covers a percentage of the tax that is owned. Beginning in tax year 2006, consumers will be able to itemize qualified purchases on their federal income tax returns (see Table 3).

Table 3. Major Tax Credits from EPACT

\begin{tabular}{|l|c|l|}
\hline \multicolumn{1}{|c|}{ Resource } & $\begin{array}{l}\text { Credit } \\
\text { Size* }\end{array}$ & \multicolumn{1}{|c|}{ Special Considerations } \\
\hline Wind & Full & None \\
\hline Biomass & Full & Crops grown specifically for energy \\
\hline Closed-Loop & Full & $\begin{array}{l}\text { Only specific coal power plants; based on \% of biomass heat } \\
\text { input }\end{array}$ \\
\hline Closed-Loop Co-Firing & Half & Does not include co-firing \\
\hline Open-Loop & Half & $>150$ kW; Does not include co-firing \\
\hline Livestock Waste & Full & $\begin{array}{l}\text { Incorporated with "livestock waste” with the American Jobs } \\
\text { Creation Act of 2004 }\end{array}$ \\
\hline Poultry Waste & Full & $\begin{array}{l}\text { Exclusion from investment tax credit (eligibility expired } \\
12 / 31 / 05)\end{array}$ \\
\hline Geothermal &
\end{tabular}


Table 3. Major Tax Credits from EPACT

\begin{tabular}{|l|c|l|}
\hline \multicolumn{1}{|c|}{ Resource } & $\begin{array}{l}\text { Credit } \\
\text { Size* }\end{array}$ & \multicolumn{1}{|c|}{ Special Considerations } \\
\hline Solar & Full & $\begin{array}{l}\text { Exclusion from investment tax credit; eligibility expired } \\
12 / 31 / 05\end{array}$ \\
\hline Small Irrigation Hydro & Half & No dams or impoundments; $150 \mathrm{~kW}-5 \mathrm{MW}$ \\
\hline Incremental Hydro & Half & Increased generation from existing sites \\
\hline Landfill Gas & Half & Exclusion from Sect. 29 tax credit \\
\hline Municipal Solid Waste & Half & Includes new units added at existing plants. \\
\hline
\end{tabular}

\subsubsection{Solar Tax Credits}

EPACT attempts to provide tax credits that cover 30 percent of the costs of installing PV systems for businesses and residences. The credits are available for systems that are placed in service or activated between January 1, 2006 and December 31, 2007. Systems that have already been installed area not eligible (see Table 4).

Table 4. A Detailed Look at EPACT Business and Residential Credits for Solar Energy

\begin{tabular}{|c|c|c|c|c|c|}
\hline & $\begin{array}{c}\text { Old } \\
\text { Incentive }\end{array}$ & $\begin{array}{c}\text { New } \\
\text { Incentive }\end{array}$ & $\begin{array}{l}\text { Credit } \\
\text { window }\end{array}$ & Cap & $\begin{array}{c}\text { Eligible } \\
\text { technologies }\end{array}$ \\
\hline $\begin{array}{l}\text { Business } \\
\text { credit }\end{array}$ & $10 \%$ & $30 \%$ & $\begin{array}{l}1 / 1 / 06 \\
12 / 31 / 07 \text { at } \\
30 \% ; \\
\text { reverts to } \\
\text { permanent } \\
10 \% \\
\text { thereafter }\end{array}$ & No cap & $\begin{array}{l}\text { PV, CSP, solar } \\
\text { hybrid lighting, } \\
\text { solar domestic } \\
\text { water heating } \\
\text { (excluding pool } \\
\text { heating) }\end{array}$ \\
\hline $\begin{array}{l}\text { Residential } \\
\text { credit }\end{array}$ & None & $30 \%$ & $\begin{array}{l}1 / 1 / 06- \\
12 / 31 / 07\end{array}$ & $\begin{array}{l}\$ 2,000 \text { per } \\
\text { system/ for } \\
\text { each solar } \\
\text { technology }\end{array}$ & $\begin{array}{c}\text { PV, solar } \\
\text { domestic water } \\
\text { heating } \\
\text { (excluding pool } \\
\text { heating) }\end{array}$ \\
\hline
\end{tabular}

\subsubsection{Wind Tax Credits}

EPACT also extended the wind production tax credit that provides a 1.9-cent-per-kWh (adjusted for inflation) tax credit for electricity generated from wind turbines over the first 10 years of a project's operations, as long as such systems are brought into service or activated between January 1, 2006, and December 31, 2007. Unlike the solar tax credits discussed above, EPACT does not include an incentive for small wind systems for homeowners and small businesses (see Table 5). The electricity must be produced by the tax payer and sold by the tax payer during the taxable year. To be eligible, producers must have tax liability and cannot use behind the meter production. 
Table 5. A Detailed Look at EPACT Credits for Wind Energy

\begin{tabular}{|l|c|c|l|c|c|}
\hline & $\begin{array}{c}\text { Old } \\
\text { Incentive }\end{array}$ & $\begin{array}{c}\text { New } \\
\text { Incentive }\end{array}$ & $\begin{array}{l}\text { Credit } \\
\text { window }\end{array}$ & Cap & $\begin{array}{c}\text { Eligible } \\
\text { technologies }\end{array}$ \\
\hline $\begin{array}{l}\text { No Distinction } \\
\text { Between Business } \\
\text { and Residential } \\
\text { Credits }\end{array}$ & $\begin{array}{c}1.9 \text { cents } \\
\text { per kWh, } \\
\text { expires } \\
\text { December } \\
31,2005\end{array}$ & $\begin{array}{c}1.9 \text { cents } \\
\text { per kWh, } \\
\text { expires } \\
\text { December } \\
31,2007\end{array}$ & $\begin{array}{l}1 / 1 / 06 \text { to } \\
12 / 31 / 07 \text { at } \\
30 \% \text {; credit } \\
\text { good for 10 } \\
\text { years after } \\
\text { installation }\end{array}$ & No cap & $\begin{array}{c}\text { Corporate, rural, } \\
\text { individual, } \\
\text { school, } \\
\text { municipal, and } \\
\text { utility wind } \\
\text { turbines }\end{array}$ \\
\hline
\end{tabular}

\subsubsection{Federal Loan Guarantee Program}

As a final incentive, the U.S. Department of Energy (DOE) announced a \$2 billion Federal Loan Guarantee Program in August, 2006 to spur investment in new energy technologies. DOE is authorized to issue loan guarantees to eligible projects that "avoid, reduce, or sequester air pollutants or anthropogenic emissions of greenhouse gases" and "employ new or significantly improved technologies as compared to technologies in service in the United States at the time the guarantee is issued.” With the initial solicitation intended for "early commercial products," DOE staff emphasized that eligible technologies needed to have passed the research and development stage yet not have widespread commercial use. For wind energy, examples of eligible technologies and projects might include advanced wind power plants, wind- or renewables-specific transmission lines, turbine or component manufacturing, testing facilities for commercial wind turbine components, and some community wind power systems. More on the program can be found by visiting http://www.energy.gov/news/3897.htm.

\subsection{OTHER FEDERAL INCENTIVES}

Beyond the incentives discussed above that generally subsidize the cost of producing electricity with renewable energy facilities, the federal government established programs that sought to encourage technologies by eliminating market barriers and by offering incentives to create markets for them. These included:

- Residential Energy Conservation Subsidy Exclusion (for businesses)

- Renewable Energy Systems and Energy Efficiency Improvements Program

- Tribal Energy Program Grant

- Value-Added Producer Grant Program

- Energy Efficient Mortgage

- Energy Star Financing and Mortgages

- Residential Energy Conservation Subsidy Exclusion (Personal)

- Conservation Security Program Production Incentive

- U.S. Department of Energy's Alternative Fuels Data Center

- Federal Government’s Green Power Purchasing Goal

In addition to providing incentives via legislative mandate and tax credits, the United States federal government also manages a number of related energy programs. A recent 2005 Government Accountability Office (GAO) report charged with "identifying major federal energy related energy efforts" and determining "the extent to which resources associated with federal energy-related efforts have changed" found more than 150 energy program activities and 11 tax preferences. The GAO grouped these incentives into eight major energy activity areas: energy supply, energy's impact on environment 
and health, low income energy consumer assistance, basic energy science research, energy delivery infrastructure, energy conservation, energy assurance and physical security, and energy market competition and education. These programs are managed by 18 federal agencies, including the Department of Energy, Department of Agriculture, and Department of Health and Human Services. Incentives that directly affect renewable energy come from two of these areas: energy supply, and basic energy science research.

According to the GAO, energy supply programs and related income tax preferences accounted for more than $\$ 6$ billion of the federal resources devoted to energy programs. Energy supply measures are managed by six different federal agencies that conduct in excess of sixty-five program activities. The estimated budget authority for those programs addressing renewable energy tended to emphasize research and development, which consumed \$349 million in fiscal year 2003. In addition, two income tax preferences - a new technology credit and exclusion of interest on facility bonds - support renewable energy at an estimated outlay of \$510 million.

The second program area - basic energy science - consists of general energy related research within the Department of Energy's Basic Office of Science. While the Office of Science's Basic Energy Science Program for fiscal year 2003 had more than $\$ 1$ billion allocated to it, most of its research focused on advancing hydrogen production, high-power batteries, and nuclear fuel purification and reprocessing efforts. Some of it - the GAO does not quantify exactly how much-went to improving existing models for solar energy conversion and for "other energy sources.”

\subsection{TECHNOLOGY-SPECIFIC INCENTIVES FROM THE FEDERAL GOVERNMENT}

The incentives mentioned above (and a few highly specific measures) can be re-categorized (and supplemented) according to the technologies they support.

\subsubsection{Wind Energy Incentives}

- $\quad$ Public Utility Regulatory Policies Act of 1978

- $\quad$ Economic Recovery Tax Act of 1981. This law allows renewable energy systems to be depreciated within five years, which is a great benefit for wind energy developers. However, many restrictions exist that often diminish the value of the rapid depreciation. ${ }^{37}$

- $\quad$ Energy Policy Act of 1992

- Energy Policy Act of 2005

- Farm Security and Rural Investment Act of 2002 (P.L. 107-171). The law offers funding assistance to farmers, ranchers, and small rural businesses that purchase renewable energy systems. Approximately \$23 million was made available annually for fiscal years 2003 through 2005 as grants and loan guarantees.

- Wind Powering America program. Managed by the Department of Energy, this initiative provides information for installing wind turbine facilities in rural areas and on Native American lands.

- Environmental Protection Agency's Green Partnership Program. Established in 1992, the program provides free technical assistance and training for those homeowners and small businesses who wish to employ renewable resources in their community.

\footnotetext{
${ }^{37}$ A Study of Increased Use of Renewable Energy Resources in Virginia. The Virginia Center for Coal and Energy Research. Performed by Virginia Polytechnic Institute and State University. Prepared for The Virginia Commission on Electrical Utility Restructuring. November 11, 2005.

http://www.energy.vt.edu/Publications/Incr_Use_Renew_Energy_VA_rev1.pdf
} 


\subsubsection{PV System (Solar Panel) Incentives}

- $\quad$ Renewable energy production tax credit, provision of Energy Policy Act of 1992, and renewed, most recently, to expire at the end of 2005.

- Million Solar Roof Initiative. This Department of Energy program supports efforts between private companies and government bodies to install PV cells on one million roofs by 2010. The program offers workshops, information, and other resources for helping to overcome market barriers and to increase the market for solar energy.

\subsubsection{Biomass and Waste-to-Energy Incentives}

- 1992 Energy Policy Act tax incentives.

- Executive Order 13134, 12 August 1999. Issued by President Clinton, the order seeks to promote biobased energy products through a comprehensive strategy of research, development, and incentives.

- Agricultural Risk Protection Act of 2000 (P.L.106-224). Included in this law are provisions for grants for research and development on biomass. Title III of the law is entitled the Biomass Research and Development Act of 2002.17

- Farm Security and Rural Investment Act of 2002 gives discount loans and grants for closed loop biomass electricity.

- Alcohol fuels tax credit. The federal tax code contains several incentives benefiting alcohol fuels derived from biomass. Among them is a partial exemption of the excise tax paid on gasoline, a credit of $\$ 0.51$ cents per gallon for converting biomass to ethanol and $\$ 0.60$ per gallon for fuel other than ethanol.

- 2005 “Billion Tons of Biomass” program from the United States Department of Agriculture. This program provides low interest loans, technical assistance, and public workshops for those wishing to generate bioelectricity or combined bio-fuel and bioelectricity.

\subsection{INCENTIVES IN OTHER STATES FOR RENEWABLE ENERGY}

Elsewhere, policy makers have created at least two major mechanisms to encourage development and use of renewable energy technologies. These mechanisms were often established (or promised to be established) during legislative negotiations that led to the partial deregulation of the states' electric utility networks. Advocates of environmentally preferable technologies sometimes played major roles in the restructuring legislation, enabling them to win concessions for support of renewable technologies after state regulation ended. They argued that, in the absence of state regulation, nothing would encourage power companies to stimulate use of energy-efficiency and renewable energy technologies.

The most common mechanisms for increasing renewable energy production consist of the public benefit fund (PBF) to support development of new technologies, the renewable portfolio standard (RPS), and energy efficiency portfolio standards (EEPS).

\subsubsection{Public Benefits Funds}

Public benefit funds (also called system benefit funds) originated in the 1990s, at a time when state policy makers considered electric utility restructuring legislation. Afraid that gains made in pursuing research, development, and implementation of environmentally preferable renewable energy technologies would end after regulators lost their sway, advocates of the novel technologies in some states won concessions for a new funding mechanism for high risk or long-term projects. The funds' income came from a small addition to the price of electricity paid by customers of companies that distributed power to them. It could not be avoided simply because customers bought power from a non-utility company in a 
deregulated system. First implemented in Washington State in 1994, the charges were endorsed by the Federal Energy Regulatory Commission in 1995 as a way to fund services that had previously been included in customers' bills of regulated utility companies. As part of the negotiations for California's restructuring law, environmental advocates won a provision for a public benefit fund that would expend at least \$872 million on energy-efficiency work from 1998 to the end of 2001. For renewable energy programs, the fund would allocate \$540 million. To develop renewable energy technologies and other programs that would likely wither after deregulation, the California Energy Commission created its Public Interest Energy Research program, which initially drew about $\$ 62$ million annually from the state’s PBF.

By mid-2003, 12 states had created PBFs. The 17 organizations that administer the funds (scheduled to total $\$ 3.5$ billion by 2017) collaborate through a nonprofit organization, the Clean Energy States Alliance. Seeking to expand the use of clean energy technologies (with special emphasis on solar, wind, and fuel cells), the organization sponsors original research and collects information and analyses. It seeks to increase the efficiency of the research of state organizations by eliminating duplication of efforts and by providing forums for the states to share knowledge and insights.

Virginia, it should be noted, is not one of these twelve states. It currently has no means for setting aside funds for research and development on new and renewable technologies. These technologies may benefit the public interest, but they may not immediately provide financial benefits to utility companies or independent generators.

\subsubsection{Renewable Portfolio Standards}

Along with public benefit funds in some cases, 18 states and the District of Columbia have established "Renewable Portfolio Standards" (also known as renewable electricity standards) that seek to increase the amount of environmentally friendly generation capacity. ${ }^{38}$ Simply put, the RPS is a legislative mandate that requires all state power producers to employ renewable energy technologies to produce a certain percentage of capacity by a fixed date. Generating companies have the option of either building renewable facilities themselves or buying credits from other companies that own them. By giving companies this choice, the RPS creates a market for credits in a way similar to the federal trading of emissions credits under the Clean Air Act amendments of 1990. It therefore blends the benefits of "command and control" with the free market approach.

Advocates of the RPS approach argue that the mechanism creates a market for renewable energy technologies and therefore spurs research, development, and implementation of the facilities. It also demonstrates to policy makers the practicality, cost-effectiveness, and non-financial benefits (such as lower pollution) that these technologies provide. As the market for renewable energy technologies grows, manufacturers gain experience and further drive down the cost of clean electricity production.

Each state that has developed an RPS defines renewable energy slightly differently. Moreover, states have chosen different amounts of renewable capacity to be used by various dates. Iowa, for example, set a goal of $2 \%$ of capacity to be implemented by 2011. New York and California, by contrast, have set goals of 24\% and 20\% by 2013 and 2017 respectively. Since these states have large established bases of power, these percentages would yield huge amounts of renewable power. The Texas RPS has often been cited as a huge success. Governor George W. Bush signed legislation establishing the RPS in 1999, requiring 2,000 MW of renewable energy to be constructed by 2009. However, because of the good renewable resources in the state (largely wind) and improving technology, producers had already installed 1,293 MW by the end of 2004, most of it consisting of wind turbines. 


\subsubsection{Energy Efficiency Portfolio Standards}

Perhaps one of the most innovative techniques for promoting more efficient electricity generators comes from new legislature requirements enacted in Texas. Texas is the first state to promulgate energy efficiency portfolio standards (EEPS) for its distribution utilities, thereby mandating reductions in load growth. While similar to systems benefit funds, EEPS establish small funds set in terms of tenths of a cent, or mills per $\mathrm{kWh}$, that are assessed as a charge that cannot be bypassed on the utility's transmission and distribution service. All customers in an affected area or class pay the same charge, with the fines collected then distributed to cover a variety of resources (from financial assistance for low-income residents to mandatory renewable generators). In contrast to systems benefits funds, EEPS set an energy savings target rather than a distinct systems-benefit charge level. An independent study undertaken by the American Council for an Energy Efficient Economy estimated that EEPS could save the country 74.2 TBtu by the year 2020 .

In 1999, the Texas Legislature restructured the state's electric utility industry and in the same bill required that its distribution utilities meet $10 \%$ of its projected load growth through a portfolio of energy efficiency programs. The projects are self selected based on Standard Offer and Market Transformation programs approved by the Public Utility Commission. In the deregulated sector of Texas, which is about $70 \%$ of total load, the distribution/wires companies can choose to implement Standard Offer Contracts with an Energy Efficiency Service Provider (EESP). The EESP receives a standard payment based on the amount of energy and peak demand savings attributed to end-use customer sites where the measures are implemented. The Standard Offer or incentive payment is $50 \%$ of the avoided cost (for the next gas-fired power plant and associated energy costs) for residential and 35\% of the avoided cost for commercial energy efficiency measures. Funds for achieving the energy efficiency goal will be included in each service area's transmission and distribution rates. 


\section{DISTRICT ENERGY}

\subsection{DEFINITION}

The University of Rochester defines district energy ${ }^{39}$ as follows:

District Energy refers to the production and distribution of energy using one or more of the following technologies: Cogeneration or Combined Heat and Power, District Heating, District Cooling, or Energy Storage.

The International District Energy Association ${ }^{40}$ notes that:

District energy systems produce steam, hot water or chilled water at a central plant and then pipe that energy out to buildings in the district for space heating, domestic hot water heating and air conditioning. Individual buildings don't need their own boilers or furnaces, chillers or air conditioners.

The concept behind district energy involves using waste energy in the form of heat that is normally produced in an electricity-generating installation and utilizing it. It may involve water that is efficiently cooled by electrical chiller or water obtained from local natural reservoirs such as a lake. Hot gas or cold may be directly piped to neighboring buildings/facilities. District cooling, effected by centralized cooling of water in a dedicated installation, is considered to be more environmentally friendly and cost-effective than having many separate, distributed cooling systems. Centralization aids operational reliability.

\subsection{SCOPE}

To provide the scope of this type of energy, Table 6 lists all the International District Energy Association (IDEA) member system locations.

Table 6. IDEA member system locations

\begin{tabular}{lllll}
\hline Alaska & Florida & Michigan & Nevada & Tennessee \\
\hline Mairbanks (2) & Orlando & Ann Arbor & Las Vegas (2) & Nashville \\
\hline Nome & & Detroit & & \\
\hline \multicolumn{1}{l}{ Alabama } & Georgia & East Lansing & New York & Texas \\
\hline Auburn & Athens & Grand Rapids & & \\
\hline & & Ginnesota & Ithaca & College Station \\
\hline Arkansas & lowa & & Jamaica & Dallas \\
\hline & & Duluth (2) & Kings Point & El Paso \\
\hline Fayetteville & Cedar Falls & Minneapolis (3) & Rochester (2) & San Antonio \\
\hline
\end{tabular}

39 http://www.energy.rochester.edu/

${ }^{40}$ http://www.districtenergy.org/what_is.htm 
Table 6. IDEA member system locations

\begin{tabular}{|c|c|c|c|c|}
\hline & lowa City & New Ulm & Stony Brook & \\
\hline \multirow[t]{2}{*}{ Arizona } & & Rochester & Syracuse & Virginia \\
\hline & Idaho & St. Paul (2) & Upton & \\
\hline \multirow[t]{2}{*}{ Phoenix (2) } & & & & Blacksburg \\
\hline & Boise & Missouri & Ohio & Burke \\
\hline \multirow[t]{2}{*}{ California } & Moscow & & & Charlottesville \\
\hline & & Columbia & Akron & \\
\hline Anaheim & Illinois & Kansas City & Athens & Washington \\
\hline Berkeley & & St. Louis & Cincinnati & \\
\hline Irvine & Chicago (3) & & Cleveland (3) & Seattle \\
\hline Long Beach & Decatur & North Carolina & Columbus & \\
\hline $\begin{array}{l}\text { Los Angeles } \\
\text { (2) }\end{array}$ & & & Dayton & Wisconsin \\
\hline Malibu & Indiana & Chapel Hill & Kent & \\
\hline Oakland & & Charlotte & Wooster & La Crosse \\
\hline Palos Verdes & Bloomington & Greensboro & Youngstown & Madison \\
\hline Riverside & Indianapolis (2) & Raleigh & & Milwaukee \\
\hline San Diego & & & Oklahoma & \\
\hline San Francisco & Kentucky & Nebraska & & $\begin{array}{l}\text { Washington } \\
\text { DC }\end{array}$ \\
\hline \multicolumn{4}{|l|}{ San Luis } & \\
\hline Obispo & Louisville & Lincoln & Oklahoma City & $\begin{array}{l}\text { General } \\
\text { Services } \\
\text { Admin. }\end{array}$ \\
\hline Stanford & & Omaha & Tulsa & $\begin{array}{l}\text { Howard } \\
\text { University }\end{array}$ \\
\hline \multirow[t]{2}{*}{$\begin{array}{l}\text { Thousand } \\
\text { Oaks }\end{array}$} & Louisiana & & & $\begin{array}{l}\text { Georgetown } \\
\text { University }\end{array}$ \\
\hline & & New Hampshire & Oregon & Capitol System \\
\hline \multirow[t]{2}{*}{ Colorado } & New Orleans & & & $\begin{array}{l}\text { Gallaudet } \\
\text { University }\end{array}$ \\
\hline & & Concord & Eugene & \\
\hline Boulder & Massachusetts & Hanover & Portland & \\
\hline \multicolumn{5}{|l|}{ Denver } \\
\hline \multirow[t]{2}{*}{ Fort Collins } & Allston & New Jersey & Pennsylvania & \\
\hline & Boston (2) & & & \\
\hline Connecticut & Cambridge (2) & Atlantic City & Harrisburg & \\
\hline
\end{tabular}


Table 6. IDEA member system locations

\begin{tabular}{llll}
\hline & Williamstown & Piscataway & Philadelphia (2) \\
\hline Hartford & & Princeton & Pittsburgh (3) \\
\hline New Haven & Maryland & & Scranton \\
\hline Storrs & & New Mexico & State College \\
\hline Delaware & Baltimore (4) & & \\
\hline College Park & Albuquerque & South Dakota \\
\hline Dover & Rockville & Las Cruces & \\
\hline Newark & Towson & & Vermillion \\
\hline
\end{tabular}

Although not an IDEA member state, Hawaii does have District Energy systems and the state does consider District Energy to be a renewable form of energy; and, it is also considered to be a form of energy conservation. The only mention of District Energy in the Energy Outlook 2006 document concerns this and is on page 24 in a discussion of State Renewable Energy Requirements.

“Qualifying renewables under Hawaii's RPS (Renewable Portfolio Standard) now include electricity conservation measures, such as district cooling systems using seawater air conditioning, solar and heat pump water heating, and ice storage, as well as reject heat in some instances."

The Energy Information Agency does not track District Energy. ${ }^{41}$

\subsection{DISTRICT ENERGY MARKETS}

There are three primary markets where district energy is most applicable:

- Colleges and universities

- Downtown in municipalities - high concentration of businesses

- Airports

What constitutes "primary markets"? To get an idea, this list from the IDEA website gives the new square footage reported for 2005. The numbers for 2006 will be reported in mid-2007. This list indicates by inference that commercial offices comprise the largest market followed by the government.

Table 7. 2005 Square Footage Reported (Source: IDEA)

\begin{tabular}{l|l}
\hline Commercial-0ffice & $10,021,005$ \\
\hline Commercial-0ther & 468,000 \\
\hline Commercial-retail/manufacturing & $2,083,545$ \\
\hline Entertainment, cultural or sporting center & 422,289 \\
\hline Government & $6,463,556$ \\
\hline
\end{tabular}

\footnotetext{
${ }^{41}$ Email from W. Horvath, EIA.
} 
Table 7. 2005 Square Footage Reported (Source: IDEA)

\begin{tabular}{l|l}
\hline Hotel & $3,526,033$ \\
\hline Other & 323,238 \\
\hline Residential & $3,706,620$ \\
\hline School, hospital or institution & $3,705,940$ \\
\hline Total 2005 reported in North America & $30,720,226$ \\
\hline Total 2005 reported beyond North America & $62,072,455$ \\
\hline Total 2005 reported in North America and Beyond & $92,792,681$ \\
\hline
\end{tabular}

IDEA makes no projections for future years. According to the report, total square footage for district energy is now 348,341,462. As seen above, the total increase for the past year was about 31 million square feet. It may be noted that there is considerable expansion of district energy taking place in the Middle East.

Several case studies on colleges and universities have been completed for the IDEA. The schools involved were Cornell, Massachusetts Institute of Technology, Princeton, University of Pennsylvania, University of North Carolina (Chapel Hill), University of Texas (Austin) (see Appendix B), University of California (Los Angeles), and Stanford. All of the schools needed to develop new sources of energy or repair existing equipment but they all wanted their systems to operate in an environmentally-friendly manner. Since District Energy is capable of producing energy with most renewable energies, each school was able to design their system around the renewable energy abundant in their community.

A case study was also performed on District Energy St. Paul, Inc., a private, non-profit, communitybased corporation located in downtown St. Paul, Minnesota. St. Paul's existing steam district heating system was converted into a hot water district heating system in 1982 and is the largest hot water district heating system in North America today. District Energy St. Paul also added a district cooling system and construction is now complete on their new Combined Heat and Power (CHP) plant. The CHP system will burn urban wood waste to produce electricity while simultaneously generating energy for St. Paul's district heating and cooling needs. ${ }^{42}$ The majority of the wood waste will come from downed trees, tree trimmings and branches from around the Twin Cities area.

\subsection{WHAT CONSTITUTES A DISTRICT COOLING SYSTEM?}

District cooling involves a central plant with chilled water that is distributed to multiple buildings. It may be as few as 2 or 3 buildings or it may be a few hundred. There will be a supply and a return. The water sent out will be 40 to $42 \mathrm{~F}$ and it warms to $54 \mathrm{~F}$. There are a variety of configurations. Sometimes the cooled water flows directly through a building. Most of the time, however, it encounters a heat exchanger at the building to be cooled. Generally, 500 sq. $\mathrm{ft}$. may be cooled per one ton of cooling. A typical commercial plant may have a 10,000 ton cooling system for cooling 2 million sq. ft. Chillers will be installed in the initial phase of a project. Storage, sometimes in the form of ice, may be added later if not a part of the initial plan. Some district cooling systems are able to make use of lake or sea water as the chilled water source.

Chilling is typically accomplished by a combination of electric drive and steam drive. The latter refers to the case where steam spins a compressor that performs the cooling as opposed to purely electrical chilling. There is a 700,000 steam driven cooling system in Manhattan that displaces $500 \mathrm{~mW}$

\footnotetext{
${ }^{42} \mathrm{http}: / /$ www.cleanenergyresourceteams.org/
} 
of peak electric load. Below is a figure illustrating both district cooling and district heating and just some of the possible energy sources.

Regarding the Cornell study mentioned above, their chilled water system consists of two types of cooled water sources. They utilize two refrigeration machines with "a chilled water thermal storage tank and a deep lake water based non-contact cooling plant connected to a buried network of recirculated chilled water. The chilled water moves the heat entering the buildings to the central plants which then reject the heat to the environment. " 43 The web site makes the claim that they have one of the most efficient district cooling systems in the world. The St. Paul district cooling system is based on an electricdrive chiller and storage tank. ${ }^{44}$ It is important to note that they chill the water using off-peak electricity in the nighttime but for daytime distribution.

\subsection{WHO DESIGNS DISTRICT ENERGY SYSTEMS}

Generally engineering firms are contracted to design energy systems. The IDEA website has a buyer's guide $^{45}$ that lists resources for district energy systems. The link there to "Consulting and Engineering Services” is especially pertinent. There is no certification process for district energy engineering. If a firm has significant experience with district energy, they are likely to be on this list. ${ }^{46}$

A recent approach is to engage an Energy Service Company (ESCO). This is a business that provides energy management services to an energy user. Services provided by an ESCO can be contracted through an Energy Services Agreement (a document including definitions, purchase and sale of contracted capacity and energy (such as steam, hot water and/or chilled water in the case of cogeneration and trigeneration plants), operation of the planned site, financing of the site, guarantees of performance, penalties, payments, default and early termination, and miscellaneous) or through specific energy management solutions identified by the ESCO that provides the best return on investment for the customer. ESCOs provide the broadest range of services to energy users. They provide energy audits, engineering design, equipment installation, construction and project management, performance monitoring and verification, performance guarantees, commissioning and O\&M, financing, and integrator. The ESCO is the only type of energy services provider whose compensation depends upon energy savings. This is the "shared savings" or "performance-based" contract where the ESCO retains a portion of the value of the saved energy as compensation. ESCOs that concentrate their efforts within the industrial sector tend to differentiate themselves by focusing within specialized industries, such as textiles or petroleum refining.

ESCO projects often employ a variety of measures and technologies to achieve energy savings, including:

- High-efficiency lighting

- High-efficiency heating and air conditioning

- Efficient motors and variable speed drives

- Centralized energy management systems

ESCOs generally act as project developers and assume much of a project's risk. Typically, they offer these services:

\footnotetext{
${ }^{43}$ http://www.utilities.cornell.edu/utl_cooling.html

${ }^{44}$ http://www.districtenergy.com/SystemsAndServices/coolingfact.html

${ }^{45}$ http://www.districtenergy.org/BuyersGuide/BuyersGuide.htm

${ }^{46}$ http://www.cogeneration.net/
} 
- Develop, design, and finance energy efficiency projects

- Install and maintain energy-efficient equipment

- Measure, monitor, and verify the project's energy savings

- Assume the risk of guaranteed energy savings ${ }^{1}$

For manufacturing facilities with significant motor-related end uses, there are potentially large energy saving opportunities through motor system and pump system upgrades. However, resources such as time, expertise, and capital are often not available to facility management for energy efficiency projects. In addition, management may be more concerned with increasing productivity and reliability than reducing energy costs.

Energy consumers tend to look for comprehensive solutions to their operating situation instead of just energy savings. While the effort may concentrate on energy efficiency improvements, there are usually collateral improvements in reliability, process control, environmental compliance, and increased productivity associated with it.

Congress authorized Energy Savings Performance Contracts (ESPCs) to encourage federal agencies to become more energy-efficient and to reduce their energy costs. ${ }^{47}$ ESPCs enable agencies to improve energy efficiency—reducing energy use and costs - through private investments. An ESPC is an agreement between a federal facility and an Energy Services Company (ESCO). The ESCO designs a project to increase the energy efficiency at a facility. The ESCO then purchases and installs the necessary equipment, such as new energy-efficient windows, automated controls, and updated heating, ventilation, and air conditioning equipment. In exchange for not having to pay for the equipment, the federal agency promises to pay the company a share of the savings resulting from the energy efficiency improvements. The ESCO is responsible for maintaining the equipment, as well as measuring the energy consumption and savings.

EPA is pursuing ESPCs to finance the significant initial cost of comprehensive energy upgrades. The agency expects to achieve a greater than 50 percent reduction from current energy consumption levels for each facility undergoing a comprehensive upgrade financed through an ESPC. A\&E Design/Build Firms provide energy audits, engineering design, equipment installation, construction and project management, and commissioning and O\&M. An ESCO might hire an A\&E firm to perform certain functions. The biggest difference between the two is that $\mathrm{A} \& \mathrm{E}$ firms do not guarantee project performance or savings.

\subsection{DOE AND DISTRICT ENERGY}

Although no federal programs are designed solely to support district energy, the U.S. Department of Energy and U.S. Environmental Protection Agency support district energy through their cogeneration and steam programs. The U.S. Department of Energy Office of Power Technologies is currently leading programs, as of February 2001, to promote the development and installation of combined heat and power technologies for distributed energy resource (DER) applications in industry, buildings, federal facilities and district energy. The CHP challenge program works with federal and state agencies, private organizations, and trade groups to raise awareness of the energy, environmental, and economic benefits of combined heat and power, including its use in district energy systems. The goal of the CHP program is to double the capacity of CHP in the U.S to 92 GW by the year 2010 and create integrated mechanical equipment in overall building system design. The program will use the National CHP roadmap to guide their activities in order to achieve the CHP goal. In the category of "Developing CHP Markets and Technologies" the goal is to install 27 GW of additional industrial CHP capacity; install 8 GW of additional buildings cooling, heating and power capacity; install $8 \mathrm{GW}$ of additional district energy capacity; and install 5 GW of additional CHP capacity in federal facilities. The second initiative is DOE's

\footnotetext{
${ }^{47}$ http://www.epa.gov/oaintrnt/energy/espc.htm
} 
Steam Challenge program, a public-private effort developed in partnership with the Alliance to Save Energy and leading providers of energy-efficient steam technologies. The Steam Challenge program helps industrial customers retrofit, maintain and operate their steam systems (including district energy systems) more efficiently and more profitably. Many CHP projects are implemented by regional application centers that were established by DOE to facilitate the deployment of CHP technologies. The Distributed Energy Program also directly sponsors CHP applications projects such as CHP Outreach and Education where a project focused on raising CHP awareness has been established. This project is called "CHP Awareness and Barrier-Busting Technical Assistance to Facilitate Implementation of CHP in the District Energy Sector."

\subsection{RELATIONSHIP BETWEEN DISTRICT ENERGY AND CHP}

District energy is hardly a household term. For policy makers with some knowledge of the subject, district energy is usually considered equivalent to old-style urban district heating systems or campus steam distribution systems. ${ }^{48}$

Many district energy systems use combined heat and power (CHP) technology to capture the usually wasted heat produced by traditional combustion for electricity. By using CHP technology, combustion facilities that are usually $49 \%$ efficient can reach efficiency levels up to $75 \%$. District energy systems can also use multiple fuels (e.g. oil, natural gas, coal, and biomass), which allows the plant to use whichever source is the least expensive. ${ }^{49}$

\subsection{CHILLERS AND PUMPS}

According to the Energy Star web site, older chillers generally have efficiencies ranging from 0.8 to $1.0 \mathrm{~kW} /$ ton and often consume approximately twice the energy of newer, more efficient chillers. Today, centrifugal chillers have efficiencies as low as $0.45 \mathrm{~kW} /$ ton $^{.}{ }^{50}$ The Energy Star web site lists efficiency data for the primary types of chillers.

\begin{tabular}{lccc}
\multicolumn{1}{c}{$\begin{array}{c}\text { Chiller } \\
\text { Type }\end{array}$} & & $\begin{array}{c}\text { Size } \\
\text { Range }\end{array}$ & $\begin{array}{c}\text { Full-load } \\
\text { Efficiency } \\
\text { (tons) }\end{array}$ \\
Centrifugal & & $100-1,500+$ & $0.45-0.68$ \\
Screw & & $40-1,100$ & \\
& water-cooled & & $0.56-0.70$ \\
Reciprocating & & & $1.1-1.3$ \\
& air-cooled & & \\
& & $1-400$ & $0.8-1.0$ \\
& water-cooled & & $0.97-1.6$
\end{tabular}

This table helps determine size and type of chiller required once the power requirement in $\mathrm{kW}$ is known. For instance, if $500 \mathrm{~kW}$ of cooling were required, then a centrifugal pump of 1000 tons that operates at $0.5 \mathrm{~kW} /$ ton would suffice. With tons of cooling now established, the pumps required for directing the water through the system may be sized. According to the Energy Star web site:

\footnotetext{
${ }^{48}$ http://files.harc.edu/Sites/GulfcoastCHP/Publications/FuelingDistrictEnergyBiomass.pdf

${ }^{49}$ http://www.nycedc.com/Library/Newsletters/Energy\&Telecom/EnergyNews_Fall2006.htm

50
}

http://www.energystar.gov/index.cfm?c=tools_resources.bus_energy_management_tools_resources Heating and Cooling, p4. 
Generally, older chillers have efficiencies ranging from 0.8 to $1.0 \mathrm{~kW} / \mathrm{ton}$; they often consume approximately twice the energy of newer, more efficient chillers. Today, centrifugal chillers have efficiencies as low as $0.45 \mathrm{~kW} / \mathrm{ton} .{ }^{51}$

The Energy Star web site lists efficiency data as follows for the primary types of chillers.

\begin{tabular}{llc}
\multicolumn{1}{c}{ Chiller type } & Size range (tons) & $\begin{array}{c}\text { Full-load efficiency } \\
\text { (kW/ton) }\end{array}$ \\
Centrifugal & $100-1,500+$ & $0.45-0.68$ \\
Screw & $40-1,100$ & \\
-water-cooled & & $0.56-0.70$ \\
-air-cooled & & $1.1-1.3$ \\
Reciprocating & $1-400$ & \\
-water-cooled & & $0.8-1.0$ \\
-air-cooled & & $0.97-1.6$
\end{tabular}

This information helps determine size and type of chiller required once the power requirement in $\mathrm{kW}$ is known. For instance, if $500 \mathrm{~kW}$ of cooling were required, then a chiller of 1000 tons that operates at 0.5 $\mathrm{kW} /$ ton would suffice. With tons of cooling now established, the pumps required for directing the water through the system may be sized.

Chilled water is moved by centrifugal pumps that use centrifugal force to propel the water along the piping. The simplest centrifugal pump has an impeller on a shaft within a spiral casing. There are two types of horizontal centrifugal pumps, the end suction (ES) and the horizontal split case (HSC). ${ }^{52}$ The end suction is smaller and, considering all types of applications, more common, but the HSC is the primary choice for district cooling. The HSC is typically used for larger applications ( $<1000 \mathrm{gal} / \mathrm{min}) .{ }^{53} \mathrm{It}$ has several advantages over the ES: It is more efficient and easier to inspect and maintain without disturbing rotor, motor, or piping. Although less efficient, some system designers will choose an ES pump based on familiarity. A third type of pump is the vertical in-line (VI) pump, named so because it is designed with the inlet and the discharge in line. The VI design takes up less floor space than the horizontal pumps, it is easy to maintain, and it offers ease for seismic restraint. The relative advantage of an HSC or a VI pump varies depending on specific application details. Internet discussions can be found where design engineers trade information and experiences in attempting to determine the right approach for their particular situation.

The most common pumping scheme for district cooling is a primary-secondary pump arrangement. This scheme originated in the 1950s and involves dividing the chilled water system into two distinct loops. The flow loop through the chiller where the cooling is produced is the primary loop, and the pump for this function is called the primary. The pump that provides pumping action to distribute the chilled water through the secondary (or distribution) loop is called the secondary. ${ }^{54}$ The secondary will push greater volumes of water for greater distances and therefore will be larger. The first row of Table 8 indicates typical pump size for the primary and secondary flow loop in a district cooling system per 1000 tons of chiller cooling.

${ }^{51}$ http://www.energystar.gov/index.cfm?c=tools_resources.bus_energy_management_tools_resources Heating and Cooling, p4.

52 “Selecting the Proper Pump” by J. David Bankston, Jr., and Fred Eugene Baker, Regional Aquaculture Center Publication \#372, http://aquanic.org/publicat/usda_rac/fact.htm

${ }^{53}$ Energy Consumption Characteristics of Commercial Building HVAC Systems Volume II:

Thermal Distribution, Auxiliary Equipment, and Ventilation by D.Westphalen and S. Koszalinski http://www.eere.energy.gov/buildings/info/publications.html

54 “Chilled Water Plant Pumping Schemes"

www.districtenergy.org/06CampConfProceeding/Track_A/6A2_Nonnenmann.pdf 
Table 8. Typical pumps used in district cooling

\begin{tabular}{|l|l|l|l|l|}
\hline $\begin{array}{l}\text { Type of district cooling } \\
\text { system }\end{array}$ & $\begin{array}{l}\text { Pumps used- } \\
\text { primary }\end{array}$ & $\begin{array}{l}\text { Comments: Head vs. } \\
\text { flow \& pump type }\end{array}$ & $\begin{array}{l}\text { Pumps used- } \\
\text { secondary }\end{array}$ & $\begin{array}{l}\text { Comments: } \\
\text { Head vs. flow } \\
\text { \& pump type* }\end{array}$ \\
\hline $\begin{array}{l}\text { For every } 1000 \text { tons of } \\
\text { chiller cooling }\end{array}$ & $30 \mathrm{hp}$ & $\begin{array}{l}50 \mathrm{ft} \text { and } 1700 \mathrm{gpm} \\
\left(386 \mathrm{~m}^{3} / \mathrm{hr}\right) ; \text { horizontal } \\
\text { split case }(\mathrm{HSC})\end{array}$ & $\begin{array}{l}230 \mathrm{ft} \text { and } 1700 \mathrm{gpm} \\
\left(386 \mathrm{~m}^{3} / \mathrm{hr}\right) ; \mathrm{HSC}\end{array}$ & $150 \mathrm{hp} \mathrm{typical}$ \\
\hline $\begin{array}{l}\text { Deep sea/lake cooling (free } \\
\text { cooling; may be some extra } \\
\text { considerations for salt water } \\
\text { and lake water) }\end{array}$ & $30 \mathrm{hp}$ & $\begin{array}{l}50 \mathrm{ft} \mathrm{and} 1700 \mathrm{gpm} \\
\left(386 \mathrm{~m}^{3} / \mathrm{hr}\right) ; \mathrm{HSC}\end{array}$ & $\begin{array}{l}230 \mathrm{ft} \text { and } 1700 \mathrm{gpm} \\
\left(386 \mathrm{~m}^{3} / \mathrm{hr}\right) ; \mathrm{HSC}\end{array}$ & \\
\hline $\begin{array}{l}\text { Absorption chillers combined } \\
\text { with waste/heat or } \\
\text { cogeneration plant }\end{array}$ & $30 \mathrm{hp}$ & $\begin{array}{l}50 \mathrm{ft} \mathrm{and} 1700 \mathrm{gpm} \\
\left(386 \mathrm{~m}^{3} / \mathrm{hr}\right) ; \mathrm{HSC}\end{array}$ & $\begin{array}{l}230 \mathrm{ft} \text { and } 1700 \mathrm{gpm} \\
\left(386 \mathrm{~m}^{3} / \mathrm{hr}\right) ; \mathrm{HSC}\end{array}$ & \\
\hline $\begin{array}{l}\text { Centrifugal chillers, } \\
\text { combined with waste/heat or } \\
\text { cogeneration plant }\end{array}$ & $30 \mathrm{hp}$ & $\begin{array}{l}50 \mathrm{ft} \mathrm{and} 1700 \mathrm{gpm} \\
\left(386 \mathrm{~m}^{3} / \mathrm{hr}\right) ; \mathrm{HSC}\end{array}$ & $\begin{array}{l}230 \mathrm{ft} \mathrm{and} 1700 \mathrm{gpm} \\
\left(386 \mathrm{~m}^{3} / \mathrm{hr}\right) ; \mathrm{HSC}\end{array}$ & \\
\hline With district heating & $\begin{array}{l}\mathrm{NA}(\text { steam } \\
\text { pressure drives } \\
\text { flow) }\end{array}$ & & & \\
\hline
\end{tabular}

Regarding flow rate: The desired flow rate in gallons per minute per ton of cooling is:

flow_rate $=\frac{24}{\Delta T}$ where $\Delta \mathrm{T}=14$ degrees (the design engineer may increase or decrease a few degrees but this is typical)

The horsepower figures above were calculated from the equation below: ${ }^{55}$

$$
h p=\frac{\text { head }(\text { feet }) * \text { capacity }(\mathrm{gpm}) *\left(\frac{8.3 \mathrm{lbs}}{\mathrm{gal}}\right) * \text { specificgravity }}{33,000 \text { footpound } * \text { efficiency }}
$$

Assuming efficiency $=0.85$ Then, the value was rounded up.

\footnotetext{
${ }^{55}$ http://www.mcnallyinstitute.com/12-html/12-11.html
} 
Table 9. Trends in pumps used in district cooling systems

\begin{tabular}{|c|l|}
\hline Horizontal split case & More efficient, i.e. > 80\% than end suction, more durable \\
\hline In line & $\begin{array}{l}\text { Smaller and easy to install; can be wall- or ceiling- } \\
\text { mounted; usually too small for district cooling }\end{array}$ \\
\hline End suction & May be chosen for ease of installation \\
\hline
\end{tabular}

Table 10. Overview of typical sizes of pumps used, \% by volume (installed base)

\begin{tabular}{|c|c|c|c|c|c|}
\hline \multirow[t]{2}{*}{ By size } & \multicolumn{2}{|c|}{ Primary } & \multicolumn{2}{|c|}{ Secondary } & \multirow[b]{2}{*}{$\begin{array}{c}\text { Hp at } \\
\text { 1700gpm }\end{array}$} \\
\hline & $\begin{array}{l}\text { Flow } \\
\left(\mathbf{m}^{3} / \mathbf{h}\right)\end{array}$ & $\begin{array}{c}\text { Head } \\
(\mathrm{m})\end{array}$ & $\begin{array}{c}\text { Flow } \\
\left(\mathrm{m}^{3} / \mathbf{h} / \mathrm{gpm}\right)\end{array}$ & $\begin{array}{c}\text { Head } \\
(\mathbf{m})\end{array}$ & \\
\hline Gould 3409 & & & $2720 / 12000$ & Тo 260 & 365 \\
\hline Gould 3410* & & & $1800 / 8000$ & To 175 & 250 \\
\hline Gould 3420 & & & $14800 / 65,000$ & To 120 & 170 \\
\hline $\begin{array}{l}\text { Bell and Gossett (lg. HSC base) mounted, dbl. suction, } \\
1800 \mathrm{rpm}, 8 \times 12 \times 22 \text { L, HSCS Series }\end{array}$ & & & $1400 / 6100$ & To 190 & 270 \\
\hline B\&G 1200 rpm; $10 \times 14 \times 20$ S; HSCS Series & 500 & 10 & & & $25^{* *}$ \\
\hline Armstrong Series $4600^{* * *}$ HSC (no. 6, $5 \times 4 \times 12$ ) & & & 400 & 200 & 260 \\
\hline
\end{tabular}

* In one example this pump was sized to function at $150 \mathrm{hp}$, a typical size for a secondary flow loop.

${ }^{* *}$ This pump may range from 20 to $150 \mathrm{hp}$. However, for the low head typical of the primary flow loop and district cooling flow rate of 1700 gpm, a typical pump as specified may result in only requiring $25 \mathrm{hp}$.

${ }^{* * *}$ This series consists of 12 different pump sizes of 1200, 1800, and 3600 rpm. Impeller material: bronze alloy 844; wear ring: bronze alloy 936.

Pump technology is considered stable with no anticipated significant technological changes. Ease of maintenance and servicing may be the most important design change driver at this time. Note that the industry is moving to variable speed drive motors that drive chillers and pumps. Efficiency improvements are significant and economic payback can be achieved in only a year. ${ }^{56}$

ORNL, IDEA, and others participated in performing several instructive university case studies ${ }^{57}$ See Appendix B for a description of the system at the University of Texas at Austin, which serves 160 buildings, has a cooling capacity of 41,000 tons (30,000 driven by electricity and 11,000 by steam), and has four chilling stations and 1 chilled water loop.

Appendix C describes the steps taken by the City of Phoenix in implementing a district cooling system.

${ }^{56}$ B. Erpelding, Ultraefficient All-Variable Speed Chilled-Water Plants, HPAC Engineering, March 2006. Figure 2 of the reference has a detailed schematic of a district cooling system under consideration and the text describes how it may be improved with variable speed upgrade and change in connections.

${ }^{57}$ http://www.districtenergy.org/guidebook/EmergingDrivers.htm 
3.9 DISTRICT ENERGY AND DISTRICT COOLING

\subsubsection{District Cooling}

Table 11 gives four examples of recent (past 10 years) district cooling projects.

Table 11. U.S. District Cooling Projects

\begin{tabular}{|c|c|c|c|c|c|c|c|c|c|}
\hline $\begin{array}{l}\text { Project } \\
\text { name \& } \\
\text { location }\end{array}$ & Status & $\begin{array}{l}\text { Project } \\
\text { time } \\
\text { span }\end{array}$ & $\begin{array}{c}\text { Total } \\
\text { building } \\
\text { space }\end{array}$ & $\begin{array}{c}\text { Building } \\
\text { types }\end{array}$ & $\begin{array}{c}\text { Developer/ design } \\
\text { consultant/builder/ } \\
\text { operator }\end{array}$ & $\begin{array}{c}\text { Contract } \\
\text { type }\end{array}$ & $\begin{array}{c}\text { Instal- } \\
\text { lation } \\
\text { sum } \\
(\$ M)\end{array}$ & $\begin{array}{l}\text { Plant } \\
\text { Type }\end{array}$ & $\begin{array}{c}\text { Max. } \\
\text { cooling } \\
\text { capacity }\end{array}$ \\
\hline $\begin{array}{l}\text { District } \\
\text { cooling, St. } \\
\text { Paul, MN }\end{array}$ & $\begin{array}{l}\text { More than } 90 \\
\text { signed } \\
\text { customers in } \\
\text { Saint Paul }\end{array}$ & 2002-03 & $17.7 \mathrm{M} \mathrm{ft}^{2}$ & $\begin{array}{l}\text { Business, } \\
\text { residential, } \\
\text { government }\end{array}$ & $\begin{array}{l}\text { District Energy St. } \\
\text { Paul/BWBR Architects/ } \\
\text { Xcel Energy /District } \\
\text { Cooling St. Paul/ District } \\
\text { Energy St. Paul }\end{array}$ & $\begin{array}{l}\text { No-interest } \\
\text { loans; } \\
\text { improvement- } \\
\text { generated } \\
\text { savings pay } \\
\text { for } \\
\text { improvements } \\
\text { in 10 yr }\end{array}$ & 5 & $\begin{array}{l}\text { District } \\
\text { cooling } \\
\text { chilling } \\
\text { plant }\end{array}$ & $\begin{array}{l}25,000 \\
\text { tons }\end{array}$ \\
\hline $\begin{array}{l}\text { Metro } \\
\text { Nashville } \\
\text { District } \\
\text { Energy } \\
\text { System, } \\
\text { Nashville, } \\
\text { TN }\end{array}$ & $\begin{array}{l}\text { 3rd year of } \\
\text { operation }\end{array}$ & 2002-03 & $8.46 \mathrm{M} \mathrm{ft}^{2}$ & $\begin{array}{l}\text { Government, } \\
\text { sports } \\
\text { complexes, } \\
\text { entertainment, } \\
\text { hotel, } \\
\text { business }\end{array}$ & $\begin{array}{l}\text { Constellation Energy } \\
\text { Source, Inc. of Baltimore, } \\
\text { MD now called } \\
\text { Constellation Energy } \\
\text { Projects \& Services Group } \\
\text { (CEPS)/CEPS/CEPS/CEPS }\end{array}$ & $\begin{array}{l}\text { 15-year } \\
\text { contract with } \\
\text { option to } \\
\text { extend for } 3 \\
\text { additional 5- } \\
\text { year } \\
\text { extensions }\end{array}$ & 6 & $\begin{array}{l}23,400- \\
\text { ton } \\
\text { district } \\
\text { chiller } \\
\text { plant }\end{array}$ & $\begin{array}{l}23,400 \\
\text { tons of } \\
\text { chilled } \\
\text { water }\end{array}$ \\
\hline
\end{tabular}
chillers and 2 1,000ton steam-absorption chillers at main plant, a 2,000-ton elec chiller at another cooling plant and several 3,900-ton satellite chillers

Nine 2600-ton Trane centrifugal chillers

Steam and chilled water are pumped through $26,000 \mathrm{ft}$ of underground pipes. Plant uses 6 Goulds chiller water pump/motor sets and 5 Goulds

condenser water pumps/motor sets

$\begin{array}{ll}\begin{array}{ll}\text { Northwind } \\ \text { Phoenix, }\end{array} & \begin{array}{l}\text { Sold-out plant } \\ \text { capacity 2004; }\end{array} \\ \text { Phoenix, } & \text { add'l plant in } \\ \text { AZ } & \text { 2006 to double } \\ & \text { system } \\ & \text { potential to } \\ & 40,000 \text { tons } \\ & \text { peak capacity }\end{array}$

2000-01 140

square

blocks

Business,

APS Energy Services /Trientertainment, County Mechanical/Trigovernment,

County Mechanical/ religious

Northwind Phoenix

20-year

contract

w/county plus

2 additional

5-year

extensions

Contract w/

City of

Chicago

through 2020

entertainment, Marchertas, Environmental

hotels,

Systems Design Inc./Chri

(nsiness,

P. Stefanos Associates

/Pepper Constr. /ThermaP2

Chicago Corp.

airport

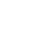

ton

district

cooling

system

96,000

55 re-

frigeratio

plants
Two 2,500-ton screw chillers, 4 existing

1,250-ton evaporative condensers, and a 500-ton chiller
Tri-County

Mechanical used

10 350-hp pumps 


\subsubsection{Representative Schematic}

Figure 30 is a simplified schematic of a district cooling system. It illustrates the usual primary-secondary pump arrangement. The chillers can be any of several types: centrifugal, screw, or absorption. Centrifugal chillers are driven by electric motors and can be open drive or hermetically sealed. Open drive chillers could be driven by steam turbines or diesel/gas engines. Absorption chillers are driven by thermal heat, typically steam, natural gas, or in some cases, waste heat. Absorptive chillers use steam or waste heat from district heating to power the chiller. The chilled water is directed via a manifold of valving to the remote buildings. Cooling is usually effected via heat exchangers or cooling coils. The water will experience a temperature increase upon passing through the heat exchanger and will return to the centrally located facility. Water pumps depicted in the figure serve to drive the flow loop. The pumps may be any combination of variable frequency drive (CFD) or non-variable frequency type. The cooling coils will involve fans and motors to drive the fans. Quite often an additional component will be thermal storage in the form of chilled water or ice. This allows for producing and storing with off peak electricity and then utilizing it higher-cost periods or during chiller outage. Note that building number two illustrates the use of a tertiary pump for additional fluid flow that is required in some situations.

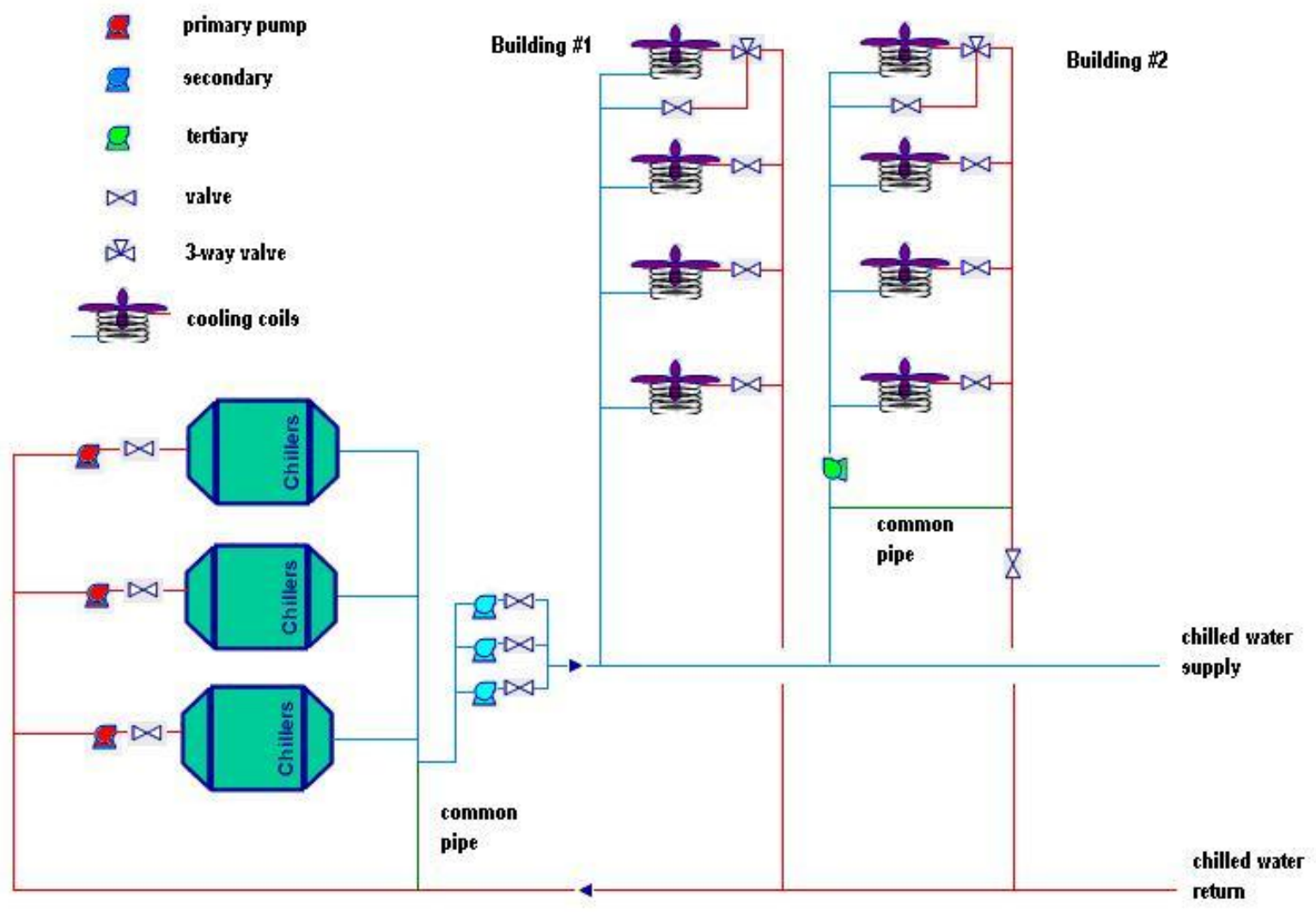

Fig. 31. Schematic of district cooling.

\subsection{ADVANTAGES OF DISTRICT ENERGY}

District energy is not new; in fact, it has been around for decades. It tends to be more economical in highdensity areas with large buildings. Recent developments that have rendered district energy to be more economically viable are: ${ }^{58}$

${ }^{58}$ http://www.energy.rochester.edu/gasmatters/ 
- Accurate metering of either hot or cold to a customer is cost effective;

- Pre-insulated pipes, easy to install, virtually leak proof, available;

- Highly efficient combined heat and power (CHP) equipment available;

- Utility industry restructure now favors efficiency and de-centralization;

- Centralized installations with efficient combustion meets emission controls; and

- $\quad$ CHP can operate on a variety of fuels, even house waste and renewables.

According to David Askew, Director of Public Involvement, British Columbia Energy Council: ${ }^{59}$

Areas of new development are well-suited for district energy. Buildings can be constructed appropriately, that is, with central heating equipment, and the energy system can be planned along with other services, such as water, sewer, and roads. District Energy can also be developed in existing urban centers, often by using old power plants. Toronto plans to develop its existing district heating system by converting a local coal-fired plant to cogeneration, using fossil fuels and other fuel sources.

District energy appears to be an approach that all stakeholders in energy policy can find valuable as the following quote indicates.

District energy is an area gas people, energy environmentalists, technology providers and policy makers will have to pay increasing attention to. .... they can do something that makes money, is environmentally benign and benefits consumers in the process. - James Ball, Editor-in-Chief, Gas Matters ${ }^{60}$

\subsection{THE USE OF COPPER FOR DISTRICT ENERGY}

Because district energy often makes use of turbine generators for producing electricity; it is a form of energy that requires some copper. However, predicting copper use due to this market segment is difficult to determine.

Quite often, district cooling is based on using chillers. According to Patricia Foley of copper.org in an article entitled "Nuts and Bolts of Chillers":

"Chillers are copper intensive, with individual units containing 3,000-6,000 lbs of copper. The US chiller tube market uses some 20-25 million lbs of copper products. "61

Although we do not currently know the extent of growth of chiller use for the district cooling segment of district energy, it appears that this niche of the energy industry does use significant amounts of copper.

\footnotetext{
${ }^{59}$ http://www. utoronto.ca/env/papers/askewd/sec10.htm

${ }^{60} \mathrm{http}: / / \mathrm{www}$. energy.rochester.edu/gasmatters/

${ }^{61}$ http://www.copper.org/applications/plumbing/techref/chill/chllrs_nts_blts.htm
} 


\section{THE FUTURE OF RENEWABLE ENERGY TECHNOLOGIES THAT USE COPPER}

Future growth is expected to be in biomass, wind, and geothermal sources (see Fig. 32). This assumes no breakthroughs in other technologies. Growth in Wind Energy has the most uncertainties associated with it. The figure below ${ }^{62}$ shows the relative growth for 2004, 2010, 2020, and 2030. Solar and municipal solid waste (MSW) will not have a great impact. The cross-hatched vertical bars for the years 2010 and 2030 show the impact of a more positive assumption, the effect of a $10 \%$ cost reduction. All technologies are unaffected in 2010.

In terms of quantity, the biggest gain is by biomass. A gain of $66 \mathrm{GW}$ is an increase of about 3 times 2004 production. In addition, under the $10 \%$ cost reduction, it would nearly double again.

Wind energy is projected to increase by 50 GW by 2030, an increase by a factor of four. Additional cost reduction would improve this by another $15 \%$. However, this projection is subject to the uncertainties mentioned above.

Geothermal is depicted as increasing by $40 \mathrm{GW}$ by 2030, about a factor of 4 over 2004. A cost reduction of $10 \%$ would increase this by an additional $39 \%$. As previously mentioned these figures may be revised downward.

\section{Growth of Renewables}

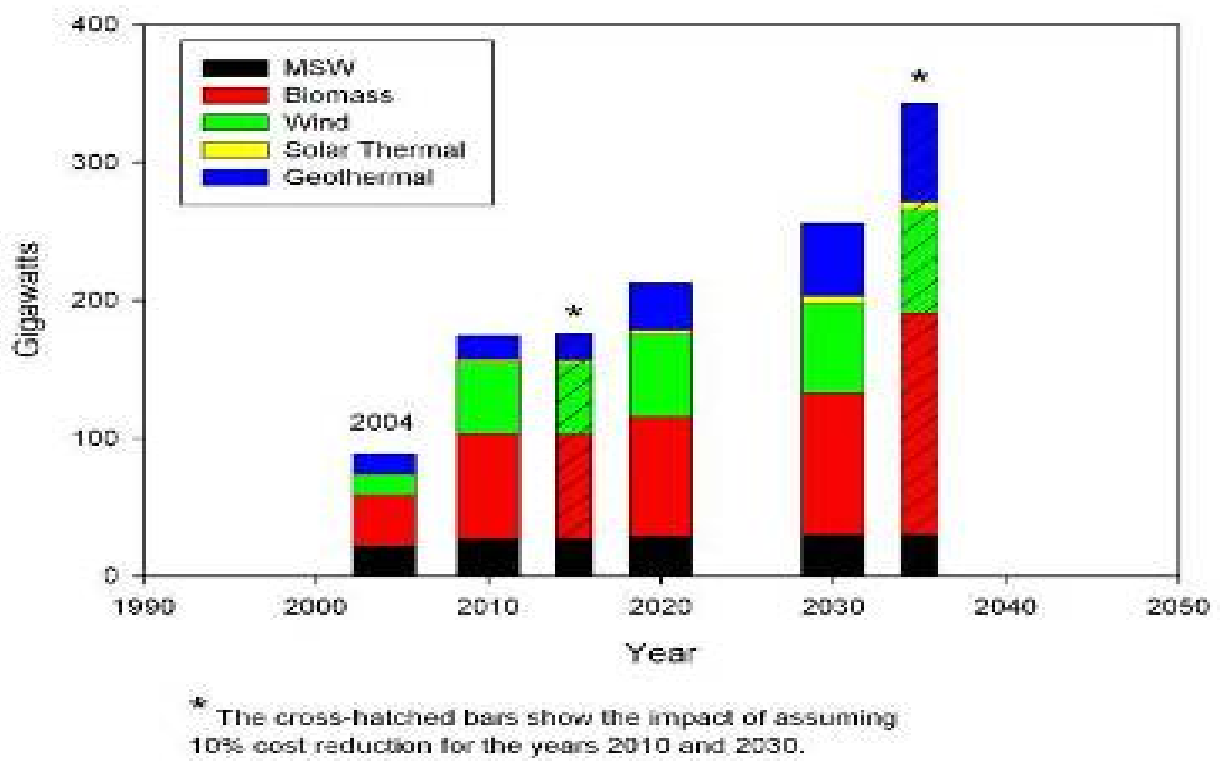

Fig. 32. Growth of renewables.

Renewables now provide $2.5 \%$ of our energy, expected to grow to $5 \%$ by 2030. Michael Miller, Director, EPRI Environment, states the following regarding global climate change: "Technology is the cornerstone of climate strategy; placing a price on carbon is not enough; need technology RD\&D policy.” Technology and timing are linked; electricity will play an even greater role in meeting the nation's future energy needs.

EPRI's view is that a "gradual transition scenario" can be defined with a factor of 4 times lower cost, and that other GHGs (not just $\mathrm{CO}_{2}$ ) must be considered. This scenario is in contrast to what EPRI defines as a "rapid transition" (to low carbon) scenario, which would cripple the economy.

\footnotetext{
${ }^{62}$ This is plotted from combining the data presented in Fig. 64 and 70 of the 2006 Annual Energy Outlook.
} 


\section{CONCLUDING ANALYSIS AND DISCUSSIONS}

The following table summarizes a comparison of technologies illustrating relative use of copper. The text following the table describes the method used to determine the amount of copper per megawatt.

\begin{tabular}{|l|l|l|l|}
\hline & Tons Cu/MW & $\begin{array}{c}\text { EIA Projected } \\
\text { Increase for } \\
\text { 2007 in mW over } \\
\mathbf{2 0 0 6}\end{array}$ & $\begin{array}{c}\text { Corresponding } \\
\text { increase in Cu } \\
\text { tons }\end{array}$ \\
\hline Wind & 2 & 4000 & 8000 \\
\hline Geothermal-residential heat pump & $3^{*}$ & 200 & 600 \\
\hline Biomass & 0.3 & 240 & 120 \\
\hline Solar thermal & 0 to 12 & $* *$ & $* *$ \\
\hline
\end{tabular}

*assumes 95\% HDPE systems at 0.01 tons/MW and 5\% DX systems at 40 tons/MW which averages to 3 tons/MW

** Technology varies with some types having no appreciable copper but others using copious amounts. Quantification and prediction are very difficult.

\subsection{METHOD FOR DETERMINING COPPER PER MEGAWATT}

For wind energy we summed the amount of copper cabling described on the CDA webpage article about the Sweetwater Wind Farm. The tons of copper divided by the output of the farm yielded about 1 ton per MW. This was combined with additional information we learned about TVA's Buffalo Mountain Wind Farm. We learned from one involved in that facility's development about the amount of copper used in the generator and other equipment. This was about 1 ton per MW. Thus, we obtained 2 tons per MW.

For the residential heat pump calculation we discussed the amount of copper in pounds used in a residential DX and HDPE geothermal heat pump. We assumed, based on research of current literature, that the average installation is $10.5 \mathrm{~kW}$. About 80,000 units were sold last year, ${ }^{63}$ and the EIA Energy Outlook reports a steady growth rate. This enables a projection.

For biomass, we assumed that the main use of copper is in a generator. We further assumed that same amount of copper per MW as used the Buffalo Mountain generator. This comes out to 0.6 tons/MW. Since some biomass is directly used in cogeneration or as a gasoline substitute, we divided this by two to get 0.3 tons $/ \mathrm{mW}$.

\subsection{CONCLUDING REMARKS}

- Wind energy combines two aspects of interest: 1) It involves a high ratio of copper to electricity generation in MW and 2) It is growing at a rapid rate near term and possibly longer contingent on continue of tax incentives.

- Geothermal energy involves several technologies, some copper-intensive (e.g., the DX heat pump). Geothermal energy use will continue to grow. It seems that the market for heat pump technologies

\footnotetext{
${ }^{63}$ Moonis Ally, Oak Ridge National Laboratory, 2006.
} 
can improve even more if residential consumers and installers can become more familiar with the advantages of the technology.

- Biomass is expected to grow. Some aspects of the technology do not lead to copper use, e.g., using ethanol as fuel. Other technologies involving small modular systems and landfill gas extraction do use electricity producing generators that require copper.

- Some types of solar thermal equipment require considerable amounts of copper. It is a market with many small companies and products that are not standardized, making a broad assessment of impact on copper usage difficult. Nonetheless it appears that this industry segment will grow and its use of copper will increase.

- Solar energy based on photovoltaics is expected to grow. However, it is such a small fraction of the total renewable output that it will not have a significant impact for at least a decade. It does not appear at this time that the technology will use significant amounts of copper.

- Hydropower is a mature renewable energy technology. The capacity of hydropower is projected by EIA to be level through 2030.

- Ocean energy has potential but is still in the early stages of development, and the EIA makes no projections. The technologies would utilize turbine generators and copper.

- The Hydrogen economy when it arrives could involve several new copper intensive applications. At present, much development must be accomplished before this is a reality.

These remarks could well be superseded by the appearance of new, disruptive inventions that could advance the spectrum of renewable options for our energy needs. 
APPENDIX A:

\section{COPPERHEART INTEGRAL COLLECTOR STORAGE SYSTEM}

(http://www.sunearthinc.com/copperheart_system.htm)

Insert pdf from website 
APPENDIX B

IDEA CASE STUDY: COLLEGE CAMPUS CHP UNIVERSITY OF TEXAS-AUSTIN 
B-2 


\section{APPENDIX C. DISTRICT ENERGY CASE STUDY: CITY OF PHOENIX}

- City of Phoenix wanted to build a new City Hall. Several buildings were already being cooled by numerous large cooling systems; City wanted one cooling option for all city buildings in the vicinity.

- City requested design consultants analyze available options.

- DOE awarded the City of Phoenix an $\$ 80,000$ grant for engineering study and design process.

- Decisions needed to be made regarding desired mechanical systems so that the best system to build could be accurately determined.

- Step 1. Select equipment for a theoretical cooling plant for each individual building, which includes redundant chiller capacity.

- Step 2. Cost estimate for each system with cost data obtained from local equipment vendors.

- Step 3. Same procedure followed for a central plant of 3,550 tons at the city hall to serve the city hall, new parking garage offices, existing municipal building, and existing Orpheum Theater.

- Step 4. Sketch conceptual plant layouts.

- Step 5. Provide estimated contract costs to install the equipment, complete with piping, controls, etc.

- Options and recommendations were presented to the City engineers. Option 1. supply the new city hall, new parking garage offices, and existing Orpheum Theater with chilled water. Option 2. supply the existing municipal and personnel buildings.

- Factors influencing the economics of a project are land costs, existing building systems, utility rate structures and rebate programs, facility usage schedules, and local climate.

- The city or organization installing a district energy system usually involves citizens affected by the system in the decision-making process.

- City decided to proceed with a design incorporating a district cooling system featuring thermal storage to supply option 2 with chilled water.

- Engineering firms and contractors started work on the construction of the new district cooling system.

- Underground piping to serve the existing buildings was installed during the construction of the city hall.

- Several months were allotted to debug the system and optimize its operations.

- Plant is in basement of city hall and is based on three 1000-ton centrifugal chillers, a redundant chiller, a cooling tower, and associated pumps.

- Bidding accepted from three major manufacturers of centrifugal chillers to get the lowest possible cost. 
- City performed an economic payback comparison of the alternative chillers.

- If the district energy system contract included an operating contractor, that contractor would then be on-site making sure the system is built to design.

- Instead of hiring individual firms for the project an ESCO could have been hired to perform all the necessary steps, including financing, in house. 